Florida International University FIU Digital Commons

6-17-2005

\title{
Autonomy and authority in the lives of children who work as domestic servants in Ghana
}

Cecilia Nana Derby

Florida International University

DOI: $10.25148 /$ etd.FI14062245

Follow this and additional works at: https://digitalcommons.fiu.edu/etd

Part of the Quantitative, Qualitative, Comparative, and Historical Methodologies Commons

\section{Recommended Citation}

Derby, Cecilia Nana, "Autonomy and authority in the lives of children who work as domestic servants in Ghana" (2005). FIU Electronic Theses and Dissertations. 2775.

https://digitalcommons.fiu.edu/etd/2775

This work is brought to you for free and open access by the University Graduate School at FIU Digital Commons. It has been accepted for inclusion in FIU Electronic Theses and Dissertations by an authorized administrator of FIU Digital Commons. For more information, please contact dcc@fiu.edu. 
FLORIDA INTERNATIONAL UNIVERSITY

Miami, Florida

\title{
AUTONOMY AND AUTHORITY IN THE LIVES OF CHILDREN WHO WORK AS DOMESTIC SERVANTS IN GHANA
}

\author{
A dissertation submitted in partial fulfillment of the \\ requirements for the degree of \\ DOCTOR OF PHILOSOPHY \\ in \\ COMPARATIVE SOCIOLOGY \\ by
}

Cecilia Nana Derby

2005 
To: Interim Dean Mark Szuchman

College of Arts and Sciences

This dissertation, written by Cecilia Nana Derby, and entitled Autonomy and Authority in the Lives of Children who Work as Domestic Servants in Ghana, having been approved in respect to style and intellectual content, is referred to you for judgment.

We have read this dissertation and recommend that it be approved.

Mary Levitt

Laura Ogden

Lois West

Hugh Gladwin, Major Professor

Date of Defense: June 17, 2005

The dissertation of Cecilia Nana Derby is approved.

Interim Dean Mark Szuchman

College of Arts and Sciences

Dean Douglas Wartzok University Graduate School

Florida International University, 2005 
() Copyright 2005 by Cecilia Nana Derby

All rights reserved. 


\section{DEDICATION}

I dedicate this dissertation to my mother Mary Aborah and to the memories of my father Francis Wallace Derby and my Grandmother Ana Adomah. 


\section{ACKNOWLEDGMENTS}

Throughout my studies at the Florida International University, I have received much love, support and encouragement, without which I might not have attained my goal of a Ph.D., from family members, friends and most importantly, from the faculty and staff of the two institutions of higher education where I have studied. I am particularly indebted to my Major Professor, Dr. Hugh Gladwin, and to the rest of my committee members, Dr. Lois West, Dr. Mary Levitt and Dr. Laura Ogden who, in various ways, hugely encouraged and supported me during my studies at the Florida International University, and for reading, editing and making comments on the many versions of this dissertation. I am also grateful to Professor (Emeritus) Betty Hearn Morrow and Professor Barry Levine for their continued interest in my professional development. While studying in the Department of Sociology and Anthropology at the Florida International University, progress for me would not have been possible without the assistance and friendships of Michelle Lamarre, Cristina Finlay, Arelis Lopez, Elena Bee, Abdy Javadzadeh, Dr. Michael Barnett, Terry Tsuji and Michael O'Brien; I will miss you all dearly.

While in Ghana, I was the recipient of immense help from my family and friends and I express my sincerest appreciation to them all. I will always be grateful to Beatrice Mensah, Janice Oduro-Dwomoh, Andrew Gyasi-Sarkodieh, Kwarteng Ofosuhene and Esther Mensah for accompanying me to the various communities for the lengthy interviews, and to George Gyasi-Sarkodie for the many updates he provided me with while I worked on this dissertation. My 
heartfelt thanks also go to Mrs. Mary Amadu, the Director of Ghana's Department of Social Welfare, DSP Comfort Boateng of the Women and Juvenile Unit of the Ghana Police Service (WAJU), the Director and Staff of Domestic Services Agency at Tesano, Accra, and the Director and Staff of Oman Agency at Dansoman, Accra. Much gratitude also goes to Professor Christina Gladwin and Dr. Barbara Walker for their help. I am also indebted to the Ghana Statistical Service for granting me the permission to use the data on child labor in Ghana. Lastly but certainly not least, I thank Mary Ama Aborah, my mother, for her love, support and belief in me. I am equally grateful to Christina and Dr. Francis Wallace Derby, Mr. and Mrs. Fred Ocansey (Department of Guidance and Counseling) and Mr. Kissa Korsah (Department of Geography) of the University of Cape Coast; Prof. Dominic K. Agyeman, Dr. Victor Ametewee, the Late Dr. John Addai-Sundiata and Prof. Mansah Prah, all of the Sociology and Anthropology Department of the University of Cape Coast and Agnes AbodomSarkodie for their immense support. Many thanks go to Mr. K. B. Danso-Manu, Head of Data Processing at the Ghana Statistical Service, for his assistance. April Dawkins, Jonathan Bulley, Garth Crosby, James Gadze and Justice and Esther Indubah, you were the greatest family away from home! I will forever be indebted to all of you. To my husband Francis Asubonteng, this certainly would not have been a reality without your assistance. To each of these people, and to the many friends and family members whom I could not mention here for want of space, we did this together. This is to you all. 


\title{
ABSTRACT OF THE DISSERTATION \\ AUTONOMY AND AUTHORITY IN THE LIVES OF CHILDREN \\ WHO WORK AS DOMESTIC SERVANTS IN GHANA
}

by

\section{Cecilia Nana Derby}

Florida International University, 2005

\author{
Miami, Florida
}

Professor Hugh Gladwin, Major Professor

Limited literature exists on Ghana's child domestic servants, and researchers have found it difficult to locate and study these children. The research for this dissertation used qualitative research methodologies and nonprobabilistic sampling techniques to make it possible to interview child domestic servants, their parents, employers and recruiters in Ghana. The findings from the qualitative analyses informed the second part of this study, which was quantitative and tested hypotheses using crosstabulations and logistic regression analyses that were based on survey data from the Ghana Statistical Service. Explanatory variables in the quantitative analyses included lineage, level of education and relationships to the household head.

This study located findings about the processes of children's recruitment into domestic servitude, their working conditions and methods of remuneration in theories of slavery to answer the question of whether or not child domestic servants are slaves. According to the findings, elite households in Ghana exploit children from rural regions because they have taken advantage of a historical 
practice that allowed children to live with older members of their extended families to provide domestic services and in return, be given the chance to receive formal education or to learn a trade. The participants in the qualitative part of this research described the treatments that they receive from their employers as slavery. Nevertheless, the processes of their recruitment and the age at which most of them accepted such job offers made it difficult to categorize a majority of them as contemporary slaves. 
I. Introduction and Need for the Study ................................... 1

Theoretical Framework ......................................................... 5

Theories of Household Survival Strategies ............................. 5

Relationship between Child Labor and

Neo-Liberal Economic Policies .................................... 8

Contemporary Child Slavery .......................................... 10

Researching Child Domestic Servitude in Ghana ........................ 14

Research Design and Analyses ................................ 16

Chapter Summary and Conclusion .................................... 17

II. Children's Childhood, Rights and Child Labor Exploitation .............. 18

Conceptualizing Children's Childhood: When is a Child No Longer a Child? ........................................................... 19

Exploitation of Children's Labor .............................................. 27

Distinguishing between Positive and Negative

Children's Labor ............................................................ 28

Child Domestic Servitude ................................................. 34

Efforts to Combat Child Labor Exploitation ................................ 39

Chapter Summary and Conclusion ....................................... 50

III. Research Methods .............................................................. 53

Qualitative Methods ....................................................... 53

Research Sites ............................................................ 54

Sampling Techniques in the Qualitative Method .................... 57

The Sample .................................................................... 61

Semi-Structured Interviews ........................................... 63

Qualitative Data Analyses ........................................... 66

Quantitative Method .............................................................. 67

Univariate Distribution of Dependent and

Independent Variables ...................................................... 69

Operationalizing Child Domestic Servitude .......................... 70

Chapter Summary and Conclusion .......................................... 74

IV. Processes of Recruitment and the Nature of Relationships between Domestic Servants and their Employers ....................... 76

Rural versus Urban Family Structures and their Influence on the Recruitment of Children into Domestic Servitude ............... 77

Processes of Recruitment .................................................... 83

Formal Recruiters ........................................................... 84

Domestic Services Agency at Dansoman ..................... 85

Domestic Services Agency at Tesano ......................... 86 


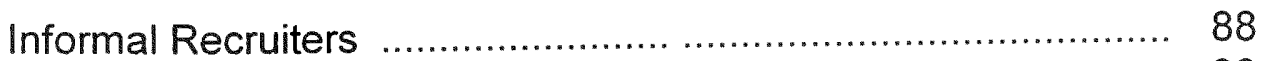

Non-Formal Recruiters .................................................. 93

Derrick: The Non-Formal Recruiter at Accra ................. 94

Sophia: The Non-Formal Recruiter at the

University of Cape Coast ....................................... 99

Ali: The Non-Formal Recruiter at Tikobo \#1 .................. 100

Ahmed: The Non-Formal Recruiter at Bonyere ............. 102

Nature and Structure of Relationships between

Employers and Domestic Servants ......................................... 107

Non-Familial Relationship ............................................ 107

Kin Group Relationship ................................................... 113

Shared-Solidarity Relationship ........................................ 117

Chapter Summary and Conclusion .................................... 122

V. The Culture of Ghana and its Impact on Child

Domestic Servitude .............................................................. 124

Lineage and Gender Structures in Ghana .................................. 125

Relationship between Gender Role Expectations and

Child Domestic Servitude ....................................................... 134

Influence of Lineage on Child Domestic Servitude:

Statistical Evidence

139

Other Traditional Practices and Child Domestic Servitude.............. 148

Chapter Summary and Conclusion ...................................... 151

VI. Child Domestic Servitude as a Form of Household

Survival Strategy ..................................................................

Economic Benefits that Accrue to Employers of

Child Domestic Servants

154

Payment for Domestic Services ............................................. 159

How are Child Workers Paid: Statistical Evidence ........................ 167

Why Domestic Servants Prematurely Leave Servitude ................. 169

Chapter Summary and Conclusion ......................................... 177

VII. Relationship between Formal Education and the

Incidence of Child Domestic Servitude .........................................

Ghana's Formal Educational System ......................................... 179

Parental Influence in the Education of their Children ...................... 181

Educational Resource Availability and Accessibility ...................... 184

Relationship between Formal Educational and

Child Domestic Servitude

195

Relationship between Lineage, Formal Education

and Child Labor Exploitation ................................................ 199

Chapter Summary and Conclusion ..................................... 202 
VIII. Child Domestic Servitude: the Question on

Contemporary Slavery

Domestic Servants who are not Contemporary Slaves

Contemporary Slavery: Perceptions of Some

Domestic Servants

Chapter Summary and Conclusion

1X. Conclusions: Historical and Economic Explanations of

Contemporary Child Domestic Servitude

Reasons for the Continued Existence of Child Domestic

Servitude in Ghana

Becoming Domestic Servants

Theoretical Implications of this Dissertation

Towards the Elimination of the Repressive System of Child

Domestic Servitude in Ghana: Recommendations.

List of References

Appendix 
I Age Distribution of the Sample .......................................... 70

II Regional Distribution of the Sample ...................................... 71

III Respondents' Relationship to their Heads of Household ................ 72

IV Distribution of Child Workers ................................................. 73

V Distribution of Child Servants .................................................. 73

VI Employment Status of the Sample ........................................... 74

VII Distribution of Ethnic Groups.............................................. 141

VII Distribution of Lineage ................................................... 141

IX Relationship between Incidence of Child Domestic Servitude and Lineage .......................................................... 143

X Bivariate Association between Reasons why Children Work and Lineage..

XI Bivariate Association between Method of Remuneration and Relationship to Head of Household.

XII Why Some Respondents Never Attended School

XIII Mean Distribution of Regional Educational Participation

XIV Relationship between Formal Educational

Participation and Regions

XV Bivariate Association between Highest Level of Education And Type of Community (Rural or Urban).

XVI Bivariate Association between Formal Educational Participation and Child Workers (Including those who Live with Own Parents) ..... 
XVII Bivariate Association between Formal Educational Participation and Child Servants (Excluding those who Live with own Parents .....

XVIII Bivariate Association between Lineage and School Participation ..... 201

XIX Bivariate Association between Lineage and School Attainment....... 202 


\section{CHAPTER ONE}

\section{INTRODUCTION AND NEED FOR THE STUDY}

In October, 2002, a Federal grand jury indicted Mrs. Grace Coleman, a Ghanaian Deputy Minister of Finance and Member of Parliament, for the role she played in her daughter's enslavement of a 44 year-old Ghanaian woman, Margaret Owusuwaah, in the United States. During a court testimony, Margaret indicated that she provided various domestic services without pay for a period of 17 months. She also stated in her testimony to the court that a $\$ 150.00$ monthly payment which had been promised her prior to her coming to the United States was never paid (US Department of Justice, 2004). Until her escape, Margaret cooked, cleaned, did the laundry and raked leaves without pay. She also provided baby-sitting services to other families, but Barbara Coleman-Blackwell, the minister's daughter, kept the proceeds. Barbara also confiscated Margaret's passport. In January 2004, the daughter was sentenced to five years in prison. She will be deported to Ghana at the end of her sentence. Her African-American husband was also sentenced to six months house arrest and three years probation. Officials representing the United States also filed papers seeking extradition of the deputy minister and parliamentarian to the United States to be tried (US Department of Justice, 2004; Ghana Home Page, 2004).

Although the government of Ghana withdrew this minister's appointment subsequent to her indictment, the stance of US officials drew sympathy from some Ghanaians, prominent among them being the minister's colleagues in 
Parliament. In an interview with the Ghanaian Chronicle, a leading newspaper in Ghana, a highly renowned and well-respected female Member of Parliament interpreted the lawsuit as Margaret's attempt to secure a permanent stay in the United States, and by so doing, had jeopardized the image of the Deputy Minister (The Ghanaian Chronicle, 2004). In this Parliamentarian's opinion, there was nothing wrong with the indicted minister's actions; all she did was to recommend Margaret to the US Embassy in Ghana for visa. Her actions, the highly respected Member of Parliament went on, would prevent any future attempts to help people from their constituencies to travel overseas for exposure and growth (The Ghanaian Chronicle, 2004). Why does a woman with the caliber of this Member of Parliament who was also a former Minister of State, seem to condone the labor exploitation of her fellow women?

The sympathy that Ghanaian parliamentarians showed towards their indicted colleague did not come as a surprise. Although Margaret was 44 years old at the time and thus qualified for employment, such abuse of labor within the household was a manifestation of child domestic servitude in Ghana. Many children provide free domestic services under exploitative conditions in that country. Ghana is signatory to the Convention on the Rights of the Child (CRC). However, urban and elite households continue to rely on underprivileged children to provide free household services. Why this type of labor exploitation or slavery eluded any official attention forms the basis of this dissertation. Given the number of children one observes working in the streets of Accra and newspaper reports about their abuses in some households, I thought no laws existed to 
protect the Ghanaian child at all. One would assume there had never been any government intervention in the exploitation of children's labor in Ghana. On the contrary, this dissertation discovered that a lot is being done to protect the Ghanaian children, albeit unsuccessfully.

When I was growing up, I observed that rural Ghana was the source of this free labor. My interactions with child domestic servants gave me an insight into how disoriented and unhappy some of them were. A number of the domestic servants lived with total strangers. There were others who lived with family members, but they were nonetheless treated as servants, rather than a part of the households. While pursuing my bachelor's degree at Ghana's University of Cape Coast, I wondered why the exploitation of children's labor within the household continued to be a neglected issue among scholars, politicians and journalists. By the time I started graduate school, I observed that at the global level, activists and international non-governmental agencies had embarked on campaigns to abolish the use of children's labor in the manufacturing sector and in sweat shops. I had become knowledgeable of the sexual abuses and other forms of violence that some domestic servants suffer. However, the plight of the Ghanaian child domestic servant seemed to evade any official notice, be it scholarly or political.

My awareness of the existence of this seemingly forgotten category of children, and the lack of extensive academic research on them, prompted this study. Research on child labor exploitation usually left out those who work within the domestic context. A couple of reasons are responsible for this. First, they 
are engaged in the informal sector, which lacks adequate record keeping (UNICEF, 1999). Second, there is the tendency for them to be considered household members rather than employees or slaves because of their location within the household (UNICEF, 1999; International Labor Organization, 2001a). Researchers found it difficult to penetrate the household setup for interviews, conduct surveys on or make observations about the exploited child. Third, "In societies where using children's work is not recognized as 'child labour' but as normal feature of society, motivation to enquire into their situation is likely to be limited" (UNICEF, 1999: 3). The children's work in other households can be seen as a mere extension of their duties so that the concept of employment is not perceived under the circumstances (UNICEF, 1999). Fourth, most people do not consider children's domestic work as hazardous or exploitative (International Labor Organization, 2001; Lange, 2000; Slater, 1997). Fifth, obscurity of child domestic servitude in research is attributable to the fact that many households that employ and abuse them are not honest about the fact that they abuse their child workers (Slater, 1997).

Consequently, it is not statistically known how many girls and boys have been enslaved in domestic servitude. The literature was missing a description of children's domestic servitude in Ghana and an explanation of why such abuse and exploitation of children's labor outlived all attempts to eliminate child labor exploitation and slavery. 


\section{THEORETICAL FRAMEWORK}

Three bodies of literature informed this research. These are theories of household survival strategies, theories of slavery and the literature on child labor.

\section{Theories of Household Survival Strategies}

Household refers to "the social group which resides in the same place, shares the same meals, and makes joint or coordinated decisions over resource allocation and income pooling" (Ellis, 1998: 1). Martin Verlet (2000) sees it as "a relatively stable community of permanent residents and consumers" (Verlet, 2000: 67). Household survival strategy, as a concept, means "every deliberate economic act by household with the ultimate motivation to satisfy the most elementary human needs, at least on a minimal level, according to the universal social and cultural norms, and without a full social integrating character" (Meert, Mistian and Kesteloot, 1997: 173). The multiple modes of livelihood (MML) and the microeconomic theory of utility maximization within the household (Kevane, 2004) are two interrelated models of household survival strategies that are relevant to this research. Although both theories support the role of choices rather than structures in human behavior, the MML (Owusu, 2001) theory places emphasis on individuals' response to structural changes while the utility maximization theory elaborates people's pursuit of the highest level of satisfaction given the information and possibilities that are available to them (Kevane, 2004). 
In the dissertation Urban Impoverishment and Multiple Modes of Survival

Strategies in Ghana, Isaac Owusu (2001) employs the MML approach to discard the notion that survival strategies are primarily associated with poor rural households. He notes that Ghanaian urban residents have employed multiple modes of survival strategies in response to the country's numerous neo-liberal economic policies, which have failed since the 1970 s. To substantiate his point, he uses another concept, the "livelihood strategies," as a "framework to capture all responses to economic change including those meant to ensure survival as well as those employed to accumulate resources" (Owusu, 2001: 3).

Although the MML strategy has a long history in Ghana and Africa at large (Owusu. 2001), the impact of recent development programs (Gladwin, 1991; Donkor, 1997; Donkor, 2001; Owusu, 2001; Hormeku, 1997; Konadu-Agyemang and Takyi, 2001; Verlett, 2000), as well as the outcomes of domestic policy mismanagement, political instability and external shocks have had urban residents combining both salaried and non-salaried sources of income as a means of survival (Owusu, 2001). As Stark (1991) further suggests, households could diversify, either deliberately or be forced to do so in response to harsh structural changes (Stark, 1991). This was particularly true for urban residents who lived on fixed incomes prior to the failed policies. Before Owusu's research, the multiple modes of livelihood were considered a means of accumulation, or a strategy for rural residents (Owusu, 2001).

Owusu's conception of 'livelihood' precludes non-monetary based interactions or networks that nonetheless augment the coping strategies of both 
rural and urban poor, as well as the accumulation purposes of salaried workers. This missing link in his notion of livelihood strategies is what Frank Ellis (1998) emphasizes. Ellis (1998) perceives a livelihood to encompass "income, both cash and in kind, as well as the social institutions (kin, family, compound, village and so on), gender relations, and property rights required to support and to sustain a given standard of living (Ellis, 1998: 3). I hypothesized, based on these arguments that it is through these additional means to coping with harsh economic realities that some children are recruited for domestic servitude.

The second model of household survival strategy is utility maximization. The main tenet of this theory is that when people make choices, they aim their actions at the maximum utility that they can derive from various combinations of the resources that they can access. The decision that goes into the provision of education of one's children is a subject of the utility maximization process. Research shows that families or households derive differential levels of utility from the education of their children, according to the gender of the children. Therefore, when choices are made about which child, boy or girl, will receive formal education, a consideration is given to the profitability of such an investment, although the future is usually not certain (Kevane, 2004). World Bank reports on education do not point to any significant difference between the primary school enrollment of boys and girls in Africa in general, and Ghana in particular (World Bank, 2004), although primary enrollment of girls tends to be higher, in some cases, than boys. Beyond primary school, girls are less likely to 
continue their education. This under-education of girls at the higher levels, according to Michael Kevane (2004) exists because

Parents think there is a low return to educating girls. Female graduates may not get jobs. They may earn lower wages than males. Parents may also prefer to educate boys for personal reasons. An educated girl may not respect her parents. She may refuse to marry a spouse chosen by parents. Parents may think it unseemly for a girl to be in a classroom with boys (Kevane, 2004: 146).

Other theories propose that parents prefer that their daughters rather than their sons drop out of school to work because they tend to be more generous than the boys (ILO, 2002c). In many cases, the incomes so generated go into the education of their male siblings (UNICEF, 1999).

\section{Relationship between Child Labor and Neo-Liberal Economic Policies}

Scholars draw a link between neo-liberal economic policies and child labor exploitation and contemporary slavery (Seabrook, 2000; Verlet, 2000). Given the principles inherent in these two theories of survival strategies, child labor can occur through salaried workers' attempt to diversify their sources of income in response to neo-liberal economic policies and other structural changes, or as a result of the households' attempt to increase utility from the labor of their members. Martin Verlet (2000) illustrates the relationship between child labor and neo-liberal economic policies through his research on child workers at Nima, a suburb of Accra, Ghana. He concludes that deregulation policies entrenched particularly in Ghana's structural adjustment programs (SAP) of the 1980 s and 1990s destabilized family structures in urban Ghana, stripping men of their positions as breadwinners while plunging children into street work. Structural 
adjustment programs required governments to undertake austerity measures

focused on decreasing government expenditure and wage labor through wage freezes, redundancies, and the abolition of welfare (Mbembe, 2001; Meillassoux, 2000). The SAP entailed

Devaluation of overvalued currencies, increases in artificially low food prices and interest rates, a closer alignment of domestic prices with world prices, an emphasis on tradeables/exportables and the gradual withdrawal of restrictions on competition from abroad (trade liberalization), privatization policies (of "parastatals" or large-scale government monopolies) a decrease in government spending, wage and hiring freezes, reductions in employment in the public sector or the minimum wage, the removal of food and input subsidies and across-the-board reductions in budget deficits as ways to invigorate stagnating economies (ECA 1989: 18-20 in Gladwin, 1999: 4).

These transformations resulted in the deregulations of the labor market, social legislation and institutional control, which led to an overall social deregulation (Verlet, 2000). A part of this is the domestic regulation, which refers to "the break-up of family units combined with the increasing fragility and destabilization of households which has been gathering pace and becoming more serious under the impact of the policies of liberalization through structural adjustment" (Verlet 2000: 67).

Following the domestic deregulations of the liberalization processes, the Ghanaian child, according to Verlet (2000), became proletarianized. He argues that male workers who were made redundant through structural adjustments became "petrified, marginalized ..." and lost their statuses as "family protector, chief and guide" (Verlet, 2000: 68). He went on to indicate further that women assumed the role of breadwinner, but their contributions were not sufficient. 
Consequently, children were drawn into the labor force. While these conclusions legitimately explain the role of women and children in the survival of their households when men cease to be the primary breadwinners, the literature shows that historically, women in Africa have almost always played immense roles in the supply of food and certain other vital resources for their households.

\section{Contemporary Child Slavery}

The 1926 Slavery Convention defines slavery as "the status or condition of a person over whom any or all of the powers attaching to the rights of ownership are exercised" (the 1926 Slavery Convention). In a not so much different definition, Orlando Patterson (1982) saw it as "the permanent, violent domination of natally alienated and generally dishonored persons" (pp. 13). That commonplace notion of slavery as the ownership of people by others is emphasized in these definitions. Until its total abolition at various times and in various countries in the latter part of the $20^{\text {th }}$ century, legal documentations gave credence to such ownership (Bales, 1999, 2000, Palmie, 1995). Slavery has, however, taken a new turn in contemporary societies. The very existence of contemporary slavery in general is being contested currently because of this difference (Van Der Anker, 2004). Today, what we emphasize is not so much the ownership of humans by others, but the processes through which their labors are acquired and exploited.

Slavery is a very fluid sociological phenomenon whose structure has never ceased to alter since its inception in the $7^{\text {th }}$ Century BC. What we 
conceptualize as slavery today is markedly different from historical forms of slavery, although the victims under both types suffer dehumanization through the loss of freewill, power and their identities.

Slavery originates from the Latin word servus, which means "a person whose life has been spared (servatus) by the captor" (Archer, 1988: 267). Its emergence occurred in reaction to the onset of private ownership and improvements in technology that led to warfare and the capture of enemies (Bales, 2000). The captives were forced to work on their masters' properties and in return, their lives were spared (Meltzer, 1980; Archer, 1988). In earlier nomadic or hunter gatherer societies, captives were killed because beside food insufficiency, their captors had no economic need for them (Meltzer, 1980).

It is on the basis of the contemporary slave's labor exploitation that Bales draws a distinction between them and traditional slaves. New slaves are subjected to violent control "... and held against their wills for exploitation" (Bales, 2000: 13). They are neither owned nor held permanently by their "masters."

This way, their perpetrators are able to avoid maintenance costs while making huge profits through violent control and exploitation of their labor. Bales characterizes them as the "disposable people" because when they become less profitable, their perpetrators discard them (Bales, 2000; 1999). The contemporary slave holder does not enjoy the sort of legal backing that traditional slave masters enjoyed. Given non-existing legal support for and documentation of contemporary slavery, they are acquired through illegal means and disposed off in a like manner. 
Kathleen Barry's clarification of child slaves in pornography helps to sharpen further the definition of contemporary child slavery in particular. She argues that "[i]f knowledge is a requirement for consent and maturity is necessary for sexual knowledge, then the use of children in pornography is by definition forced, and therefore a form of sexual slavery" (Barry, 1984: 99). Her definition emphasizes the subject's capability to adequately understand the responsibilities associated with their assigned positions, in this case domestic servitude, and to give informed consent. Based on this perspective, I took the subject's capability to understand and to consent to their recruitment into consideration while trying to conceptualize their positions as slaves or not. This was in addition to the various positions clarified earlier.

Although writing in an era when contemporary slavery was not as pronounced as today, Barrington Moore (1967), in Social Origins of Dictatorship and Democracy: Lord and Peasant in the Making of the Modern World, drew attention to differential levels of labor exploitation and slavery in particular. He coins the concept of labor-repressive systems characteristic of which is a continuum of labor exploitation. Slavery exists at one end on that continuum. The permanent ownership of the traditional slave, their legal transferability and the associated loss of their position as social beings were the worst repressive treatments that traditional slaves have had to endure. The explanatory factor in this regard is dehumanization, which, inarguably, occurs through permanent ownership alienating the victims from their social and natal identities for the traditional slave. Today, dehumanization occurs through forced labor and 
exploitation. Many a contemporary slave is acquired through forced kidnapping and trafficking while others, although volunteering their participation in the job in question, end up in slavery.

Moore did not consider the inaccessibility of incomes to subjects as repression. Consequently, he excluded the American family farms of the midnineteenth century and hired agricultural laborers. He held that although there may have been the exploitation of the labor of family members, this was done by the head of the household and with minimal assistance from the outside. The lack of outside interference in the exploitation of the labor of household members made it impossible for such labor use to be repressive, he observes. He excludes hired labor from his model because they have "considerably real freedom" to refuse jobs and move about.

Moore also identified pre-commercial and pre-industrial agrarian systems as not necessarily repressive if "there was a rough balance between the overlord's contribution to justice and equality." The exclusion of hired labor in agriculture and pre-commercial and pre-industrial agrarian systems is not disputable - the hired labor exercises freedom over their employment and most likely over the disbursement of their incomes.

What becomes significant, given the argument above, are the processes of alienation, which is of utmost relevance in the conceptualization of contemporary slavery. Ivan Kopytoff's (1986) article, "Cultural Biographies of Things: Commoditization as Process" likens the procedures of alienation to the commoditization of the subjects through what he refers to as their "culturally 
informed economic biographies." The first stage of commodization is the capture, kidnapping, sale or resale of the victims. This is how they become dehumanized (Kopytoff, 1986). The end product of the entire commoditization process is the victim's rehumanization. Kopytoff (1986) holds that when individuals become dehumanized, their original identities such as those internalized while living with their parents and close relations, are lost and are replaced through rehumanization. For the contemporary child domestic servant, rehumanization involves "...the internalization of roles associated with their underdog slave statuses" and other expectations that come with living in other households. "The point of removal from their original households, dehumanization and rehumanization make up the different phases of their culturally informed biographies" (Derby, 2003: 20-21).

\section{RESEARCHING CHILD DOMESTIC SERVITUDE}

My dissertation aims at exploring children's servitude in Ghana, primarily through the qualitative research techniques. Two sets of research questions guide this dissertation. The first set derives from the literature and my encounters with child domestic servants in Ghana. The qualitative part of this dissertation focuses on answering these questions. Findings from these questions form the bases of the second set of research questions and hypotheses. Based on the above theoretical framework, the ethnographic study of child domestic servants in Ghana aims at answering four broad questions: 
- Research Question 1: what are the processes of recruitment of child domestic servants in Ghana?

- Research Question 2: what are the responsibilities of child domestic servants and in what ways do their locations within the employing households complement their efforts of multiple modes of survival strategies?

- Research Question 3: in what ways, if any, are domestic servants remunerated for the services that they render? If they are remunerated, who receives their incomes?

- Research Question 4: considering the processes of recruitment, methods and types of remuneration, and working conditions, are Ghana's domestic servants slaves?

The quantitative analyses answer the following questions:

- Research Question 1: Does lineage significantly affect domestic servitude, relationship between child workers and their employers, and the working conditions of children?

- Research Question 2: Which combination of factors determines employee satisfaction with their working conditions?

- Research Question 3: is there a statistical association between the domestic servant's relationship to the head of household and how they are remunerated for the services that they provide?

- Research Question 4: What is the relationship between formal education and incidence of child domestic servitude in Ghana?

While answering the above questions, I hypothesize that:

- there would be a statistical differences between domestic servants from matrilineal and patrilineal ethnic groups as far as relationships between the servants and their "employers," and their working conditions are concerned;

- relationship to the head of the household, reasons for working, method of pay and whether or not the respondent is paid determine the level of satisfaction with their work; 
o the method of remuneration for the services provided is partially determined by the servant's relationship to the head of household;

- children of school-going age would not participate in formal education if they enroll in domestic servitude.

\section{Research Design and Analyses}

This study is both qualitative and quantitative. The qualitative analysis is based on an exploratory study that I did on child domestic servants in Ghana in the summer of 2003. There were four samples. The first sample consisted of current domestic servants or older women who spent part of their childhood serving other households. The second sample consisted of intermediary agencies or individuals who recruit children or adults for households' employment. The third consisted of parents whose children had served or were still serving other households. The fourth sample comprised employing households. Officials from the Social Welfare Services and the Women's Ministry were also interviewed. A snowball sampling technique was used in this study. I used a 2001 survey that the Ghana Statistical Service administered on over 10,000 households for the quantitative analyses.

The qualitative analyses aimed at providing an exploratory description of Ghana's domestic servants. Interviews were tape-recorded, transcribed and analyzed manually. The quantitative analyses were both descriptive and explanatory. The variables measured included the number of working hours of respondents, their ages, their duties, the method of remuneration (if they are paid) and who receives it, their ethnic, religious and educational backgrounds and their parents' socio-economic backgrounds. 
A detailed explanation of the sampling techniques, methods of data collection and the analyses in both the quantitative and qualitative research are given in Chapter Three of this dissertation. Prior to that, Chapter Two discusses the processes of socialization of the Ghanaian child, child labor in general and contemporary child slavery. In Chapters Four through Eight, I discuss the analyses and the findings in the qualitative and quantitative studies. My conclusions and recommendations are given in Chapter Nine.

\section{CHAPTER SUMMARY AND CONCLUSIONS}

Many factors prompted this dissertation. The paucity of literature on child labor in general and on domestic servants in particular was prominent among them. As I will explain in Chapter Two, existing research on households usually mistook domestic servants to be the children of the household heads, or they were not researched at all. Given this knowledge, methodologies and sampling techniques for this research aimed at penetrating the household barrier to reach child domestic servants. The limited scientific knowledge on Ghana's domestic servants made this study primarily exploratory. That notwithstanding, I located the experiences and the meanings that domestic servants attach to their working conditions and statuses in earlier definitions of traditional and contemporary slavery to answer the question of whether or not they can be categorized as slaves. 


\section{CHAPTER TWO}

\section{CHILDREN'S CHILDHOOD, RIGHTS AND CHILD LABOR EXPLOITATION}

Literature abounds on child labor exploitation in general (Banpasirichote, 2000); its pervasiveness (Ramanathan, 2000; Bales, 1999, 2000), and its perceived impact around the world and efforts within the international community to eliminate it. Scholars have propounded some theories to explain its incidence and why efforts to eliminate it have failed (Blagbrough, 1999). The international community including the League of Nations, International Labor Organization (ILO) and United Nations (UN) have adopted and enforced many treaties that are aimed at protecting vulnerable members of society and at preventing labor exploitation from degenerating into slavery. Among these are the League of Nations' Slavery Convention (1926), the 1956 Supplementary to the 1926 Slavery Convention, the Declaration of the Rights of the Child (1959), the ILO Convention 138 concerning the Minimum Age for Admission to Employment, and the UN Convention on the Rights of the Child and Convention 182 on the Elimination of Worst Forms of Child Labor.

This proliferation of treaties on the part of the international community notwithstanding, critics observe that they do not directly address strategies to eliminate child labor, are vague on their conceptions of childhood, and tend to be permissive of child labor exploitation. This chapter outlines child labor in general 
and discusses the issues raised in some relevant treaties and how critics have evaluated them.

\section{CONCEPTUALIZING CHILDREN'S CHILDHOOD: WHEN IS A CHILD NO LONGER A CHILD?}

"Childhood" may refer to a "...time of innocence to be protected from the brutal aggression of the real world; a period of latency during which a child needs shelter while growing up until he or she is finally ready to confront reality" (Schlemmer, 2000: 4). The literature, however, illustrates a difficulty in the conceptualization of child labor and child slavery (Gendreau, 2000; Derby, 2003). This difficulty extends to the definitions generally accorded childhood. The international community and many countries define the child as any person below the age of 18 years. This cutoff age is also the mandate for United Nations International Children's Emergency Fund (UNICEF). Some researchers consider this age as a Western political construct (de Waal, 2002) whose definition was based on perceived vulnerabilities of children (Landsdown, 1994) and thus does not necessarily capture what the realities are in many developing countries.

The political construction of childhood derives from two types of vulnerabilities - inherent and structural (Landsdown, 1994). Children's inherent vulnerability refers to the outcomes of their physical weaknesses, immaturity, and lack of knowledge and experience, which causes them to be "dependent on the 
adults around them" (Landsdown, 1994: 34). Structural vulnerability of children, on the other hand, "derives from historical attitudes and presumptions about the nature of childhood"... which lead to their "complete lack of political and economic power and their lack of civil rights" in societies" (Landsdown, 1994: 35). The impact of these vulnerabilities is further compounded by children's statuses as minorities given the cutoff age of 18. Any person who is defined as a child, whether or not old enough to accept employment, does not enjoy civil and democratic rights (de Waal, 2002). They cannot sign contracts, have access to money, voting rights, rights to express their opinion or have access to courts (Landsdown, 1994; Ramanathan, 2000).

The implication of this is that their parents exercise the right to offer them to work and to even be allowed to receive the proceeds from their children's labor (Ramanathan, 2000). Usha Ramanathan (2000) suggests that "...the labour of the child worker is perceived as an 'asset"' ... and the minority statuses of children puts this asset at the disposal of persons other than the children themselves" (Ramanathan, 2000: 148). Therefore, when unfairly treated, they cannot, without an adult involvement, seek recourse through the law courts. Unfortunately, conventions seeking to address the rights of children do not empower them to access political and civil rights. It is in view of this, according to Alex de Waal, that the United States has not acceded to the Convention on the Rights of the Child (CRC). The reason behind this is the notion that these rights are not enforceable given the assertions above (de Waal, 2002). 
Both the 1959 Declaration and the CRC hold that as human beings, children must have care, protection and grow up in loving families. The Declaration emphasizes the need for every child, irrespective of her or his sex, nationality, race, religion, color, language and political affiliations to "have a happy childhood and enjoy for his own good and for the good of society" their rights and freedoms that the Declaration stipulates. The child, the Declaration further specifies, has to grow up in an atmosphere of care, affection, and of moral and material security. They are to be protected against neglect, cruelty, and exploitation and trafficking. Member States are required to provide, through legislature, the atmosphere conducive to the child's protection and security. Children are entitled to free and compulsory education, which will enhance their integration into and their promotion of their cultures. Additionally, they must have "full opportunity for play and recreation, which should be directed at the same purposes as education..." Finally, the child shall not be admitted to employment until he or she attains the minimum working age.

In addition to reiterating the rights and freedoms set forth in the 1959 Declaration, the Convention on the Rights of the Child (CRC) defines the child as "a boy or girl under the age of 18 " (CRC, 1989). The main premise of this convention is that the child is a human being who, although an individual, belongs to a family and a community and hence must be accorded "the full range of rights". It is a fundamental right of every child to enjoy an uninterrupted childhood and to fully participate in basic education until age 15, or as the laws of their respective countries allow. The Convention protects the child by 
establishing standards on health care and education with the child at the centerstage. The kind and extent of legal, civil and social services necessary for the child's successful integration into society also constitutes a major component of the CRC.

In sum, the CRC is a set of standards and obligations that spell out "the basic human rights for all children, everywhere, all the time: the right to survival; to develop to the fullest; to protection from harmful influences, abuse and exploitation; and to participate fully in family, cultural and social life" (CRC, 1989). Since its adoption in 1989, 191 countries have ratified it. This makes it the most adopted international human rights treaty in history.

The age of 15 , below which children are required to remain in school, as the CRC stipulates, coincides with the minimum age at which children can be admitted to employment, according to the Minimum Age Convention of 1973 (C138). Earlier conventions had allowed 14 year old children to work in industry. The 1973 convention took into consideration the right of every child to receive at least the basic education. It was anticipated that by age 15 school-going children would have completed the basic education or would be preparing to. The Minimum Age Convention also permits employment of 13-year-old children for light work, while 18 year olds could work in hazardous jobs. Children aged 16 could also work in hazardous occupations, but under certain strict conditions. In less developed countries where educational facilities are insufficient, the Convention set the minimum age at 12 . It remains at 14 for Mauritania, Malawi, Ecuador, Colombia, the Dominican Republic and others. Barbados, Costa Rica, 
Dominica, Japan, Germany, Ghana and other countries set theirs at 15. Tunisia, the United Kingdom, Kenya, France and Brazil have their minimum working age established at 16.

In the United States, the Fair Labor Standards Acts (FLSA) provides the ages at which children may work and in what occupations (Child Labor Coalition, 2005). The minimum age for non-agricultural occupations is 14 years. In such occupations, children must work a maximum of three hours on a school day and up to 18 hours in a school week. They may be allowed to work 8 hours a day and 40 hours a week when school is not in session. The hours they work must be between 7 a.m. and 7 p.m. or 9 p.m. on June 1 through Labor Day when evening hours are extended. In addition, children at any age could deliver newspaper, work in radio, TV, movie or theatrical productions, work in businesses owned by their parents, and baby-sit or perform minor chores around the home. They should not work in the mining or manufacturing industries at all (Sunoo, 2000; Child Labor Coalition, 2005).

It is in regards to the minimum age at which children can be admitted into work and the age required of them to remain in school that a number of criticisms have been leveled against the international community. The authorization of children's work at age 15, and in some cases below that age, places them at risk of labor exploitation. As some scholars of child labor exploitation observe, children's participation in formal education could give them some opportunity to participate in the labor market. However, the reverse is not always true employment might prevent children from receiving formal education. 
Consequently, when Convention 138 permits the already less developed

countries to lower the minimum age in the face of lack of educational

infrastructure, more children become available for labor exploitation and the incidence of high illiteracy rates among the peoples of these countries increases.

As Ramanathan (2000) suggests, these laws indicate to scholars and activists

against child labor that nobody is really seeking to eradicate this phenomenon.

As Alain Morice (2000) puts it,

Anyone requiring proof of the ambiguity of the laws meant to be protecting children from exploitation need look no further than their relatively feeble efficacy by comparison with their objectives, i.e. if not actually to eliminate the phenomenon, then at least to bring it under strict control. And what better undermines a law's credibility than for it to be seen to be incessantly flouted? (Morice, 2000: 196).

I notice that what the $\mathrm{CRC}$ and the Minimum Age Convention have done is to prohibit child labor under certain flexible terms, consequently authorizing children's work in countries where they are most vulnerable.

This problem could be compounded with the added ambiguity of the category of people referred to as the "youth". Like the concept of childhood, "youth" is also considered a Western political construct which does not carry any well defined meaning (de Waal, 2002). Alex de Waal (2002) therefore refers to the "youth" as a "... problematic, intermediary and ambivalent category, chiefly defined by what it is not: youths are not dependent children, but neither are they independent, socially responsible adults" (de Waal, 2002: 15). They are “... not typically conceived of as productive and constructive social actors, nor, as they often are in reality, as victims, but rather as potential sources of political 
disruption, delinquency and criminality" (de Waal, 2002: 15). We hardly know of the boundaries that set the category of youth apart from any other age group.

Childhood and youth are said to not fit the realities of other non-Western cultures because "sequences of maturing" existing in these other cultures tend to differ from Western cultural environments (de Waal, 2002: 15). In some traditional African societies, the sequence of maturing for males is "child-single man/warrior/laborer/married self-supporting adult-elder". For females, the sequence is girl-wife-mother (Aryee, 1997). In Western and former colonial countries, the sequence of maturing is school-employment. As de Waal suggests, the incidence of high unemployment rates and advancement in schooling make this sequence not so well defined. After high school, people might go on to attain college degrees and to stay longer to acquire post-graduate degrees. At the end of university education, it is not always certain if they would get employment, this making their statuses less specific.

While this latter pattern is true for many African countries, the interplay between traditional processes of socialization and Western sequence of maturing blurs further the definitions of childhood and youth. In traditional African cultures, children leave that category of childhood when they ascend the traditional hierarchy of economic independence (Argenti, 2002). For males in pre-colonial Africa, this meant the attainment of a level of "economic importance that would permit them to acquire wives, build their own compound and become economically viable agents" (Argenti, 2002: 125). 
Furthermore, African children as well as those in most of the world, especially those in rural regions, do not experience exclusive childhoods characterized solely with schooling and play. It is customary for them to provide services within the household and to be involved in their family's economic activities. Children who are fortunate in such cultures to go to school have to combine formal education and household chores with work on farms (Berlan, 2004 ) or with street work (Verlet, 2000). An estimated $95 \%$ of children living in farming households in Ghana work on farms, and an unknown percentage of that combine school with this economic activity (Berlan, 2004).

When tradition and political constructions of childhood grant adults so much power over children while these children are not able to adequately access formal education and consequently be equipped with an understanding of legal documents protecting them, it is not very difficult to conclude that there is a marked disconnection between realities concerning children and the fight to protect them from abuses and exploitation. Therefore, in an environment where children cannot read, and even if they could, cannot confront authority when they are being forced to work, conventions that are aimed at protecting them but do not empower them to possess civil, political and economic rights, tend to be inadequate. Additionally, the traditions that emphasize a strict adherence to a pattern of socialization that instill in children the need to obey and to respect adults also stand in the way of the successful campaign against child labor exploitation (Argenti, 2002; Nukunya, 1994; Berlan, 2004). 


\section{EXPLOITATION OF CHILDREN'S LABOR}

This chapter describes the difficulty of conceptualizing child labor. The complexity in conceptualizing this phenomenon derives from disparities in sociocultural contexts within which children work, and the conflicting approaches that the international community has adopted to fight the exploitation of children's labor. If persons who are aged below 18 do not have civic and political rights, but some of them are permitted to work, they stand a high risk of exploitation. Given children's and their family's benefit of their work, it is very difficult to recognize every children's work as labor exploitation. Nevertheless, child workers are usually victims of labor exploitation.

Very limited literature exists on how many children work. However, an estimated 400 million children work around the world, 250 million of them work under exploitative conditions (Cox, 1999), and there are approximately 27 million contemporary slaves (Bales, 2000; 1999). According to Amanda Berlan (2004), an estimated one-third of all children aged 14 years and under in Sub-Saharan Africa work. Nearly $70 \%$ of them work in the agricultural sector (Berlin, 2004). In Egypt, approximately $7 \%$ of the workforce is made up of children under 14 years who work on cotton fields. They travel to work in overloaded trucks some of which have been involved in fatal accidents in the past (Mikay, 1997). This section draws on this categorization of exploited workers to distinguish acceptable forms of children's work from potentially dangerous and exploitative children's labor. 


\section{Distinguishing between Positive and Negative Children's Labor}

Lia Fukui (2000) broadly defines labor as any activity aimed directly or indirectly at helping households meet their basic needs, namely food, shelter, clothing, health and education. Ordinarily, adult members of households bear responsibility of providing labor for the households to meet their required basic needs. Child labor occurs when children shoulder the responsibility of fending for their families (Fukui, 2000). In fact, it refers to "... any economic activity contributing to the production of goods and services (Mbaye and Fall, 2000). In poor working class families, children contribute to their families' welfare by taking care of household chores in order to free up adult labor for work outside the households to generate income for their families. When household income is not sufficient to meet their basic needs, the family suffers absolute poverty (Banpasirichote, 2000). Under such circumstances, the children's labor might be indispensable.

Child labor, when not exploitative, could be beneficial to the child's development if they work under the guidance of adult members of their households or communities. Some families give their children away with the intentions that they may have a better life and probably be provided formal education in the cities (Banpasirichote, 2000; Verlet, 1998; ILO, 2001a). This occurs especially where rural poverty and its lack of infrastructure relative to urban centers are more pronounced. As Fukui (2000) notes, children's work around the house is a major component of informal socialization processes or apprenticeship if these tasks are done under the guidance of adults. This is in 
view of the fact that the working child can get skill training from their work (Fukui, 2000; ILO, 2001a; van Gennep, 1960). The rest of the literature emphasizes this conceptualization of children's work either as socialization or exploitation outside their homes. These distinctions are discussed below.

The International Labor Organization differentiates between positive and negative children's work, while scholars like Martin Verlet (2000) draws a distinction between children's domestic work and child labor. Children's work is identified as positive if it is considered functional and contributes to their socialization (Derby, 2003; Lange, 2000). Functional children's work contributes to the welfare of their families, provides "them with skills, attitudes and experiences..." and help "...them to be useful and productive members of society during adulthood" (International Labor Organization and Inter-Parliamentary Union, 2002: 15). This is what Verlet (2000) refers to as children's domestic work.

Verlet's research on child labor in Ghana led to the differentiation between two types of children's domestic work. The first type of children's domestic work refers to those children, especially girls, who go to school and work as hawkers, street or marketplace vendors for their mothers, aunts or elder sisters. The proceeds from children's work go to supplement their family's income (Verlet, 2000; Fukui, 2000; Banpasirichote, 2000; International Labor Organization and Inter-Parliamentary Union, 2002: 15). The second type of children's domestic labor occurs when they are sent to live with and help their grandparents on their farms in rural Ghana to (Verlet, 2000). 
Rites of passage encompassed in socialization processes of some cultures exemplify these positive or children's domestic work. Van Gennep (1960) differentiates between physical and social rites of passage. Social rites of passage refer to ceremonies and responsibilities, which come with physiological changes in girls and boys (van Gennep, 1960). Physical rites of passage, on the other hand, represent the physiological changes that boys and girls experience as they go through puberty. "Social rites extend over a long period, depending on the intended occupation of the child. At the end of the period, it is expected that the child, who should be closer to becoming a young adult, must have learnt a trade already" (Derby, 2003: 4).

In the population of study, the type of training that a child receives during socialization tends to be culturally and geographically specific. Different geographic areas in Ghana specialize in different economic activities, and this has historically determined what children learn through informal socialization. Among rural Ashantis and the populations of other forest areas in Ghana, for instance, boys and girls learn gender related farming skills before they become adults. Girls are made to learn how to use the hoe to clear weeds from farms, to gather forage or uproot tubers, while the boys focus on clearing the land for farming. Back home, both boys and girls go to fetch water from the streams and rivers. The girl's day will not end there - she will continue running errands to assist her mother prepare the evening meals and to clean after that. The boys will spend time interacting with male adults of their households. 
Negative children's work, on the other hand, is synonymous to what Verlet and other scholars generally define as "child labor." It is the exploitation of children's labor, which the Anti-Slavery Society defines as

...the employment of children in conditions which, taken together and viewed in the context of the social and economic background of the region, are likely to be harmful to their mental, physical or moral and eventually to the development of their potential (Sawyer, 1988: 13).

Whereas the distinction between negative and positive children's work sensitizes scholars to the socio-cultural context surrounding children's employment, that differentiation tends to be inadequate in helping scholars to conceptualize the overall impact of the exploitation of children's labor. As I observed in my M.A. thesis, a large number of children whose work qualifies as child labor usually work under slavery conditions (Derby, 2003).

Many exploited children are obtained through trafficking. From Benin, children are trafficked into Nigeria, Ghana and the Gabon for exploitation on farms (US State Department, 2001). From Ghana, children are trafficked for farm labor in the Côte d'Ivoire, Togo and Nigeria (US State Department, 2001). In Asia, children are trafficked from India internally or to other Asian and Middle Eastern countries. Nepalese and Bangladeshi children also end up in India through trafficking (US State Department, 2001). Some victims of trafficking end up domestic servitude. There have been newspaper reports of their abusive experiences. David France (2000), for instance reports of a Cameroonian girl who worked 16 hours a day for over four years without pay in the United States. Prior to sending her to the United States, her employers were sending her to the 
United States, she was promised to send her to school, but this was never to be until she was freed and rehabilitated after four years.

In India, child labor victims are employed in the manufacturing of beedi (cigarette), matches, fireworks and explosives, glass and carpets, and in glass polishing, brassware making and mining industries respectively. Working children in agriculture are at risk of being injured by metals that accidentally drop down, sustain machete and sharp knife injuries, inhale dangerous chemicals including pesticides and acids (Burra, 1995; Mishra, 2000; Mikay, 1997;

Sudarsan and Raghavan, 2001; Tucker and Ganesan,1997). Some children who traveled on overloaded trucks to the fields of Egypt lost their lives through motor accidents (Mikay, 1997). In the lock-making factories of India, child workers inhale emery powder, toxic substances and metal dust. From beedi rolling to glass polishing, underage child slaves in India suffer many respiratory diseases (Mishra, 2000).

Children are also exploited in the sex industry. Sexual exploitation is defined in this context as "a practice by which women are sexually subjugated through abuse of women's sexuality and or violation of physical integrity as a means of achieving power and domination including gratification, financial gain, advancement" (Doezema 1998: 35). When organized, it "is a highly profitable business that merchandises women's bodies to brothels and harems around the world" (Barry, 1984: 39). When practiced individually, "it is carried out by pimps whose lifestyle and expensive habits are supported by one or two women whom they brutally force to sell their bodies for his profit" (Barry, 1984: 39). 
Research shows that childhood traumas, kidnapping and control by organized criminals lead some children and women into prostitution (Barry, 1984). Stepfathers and uncles are usually the main offenders. In the film The Day My God Died, children some of whom were only 7 years old, were kidnapped, drugged and trafficked from neighboring towns and villages into Bombay, India where they were auctioned at a slave-trading market for prostitution. In another documentary, Sacrifice by Ellen Bruno, the children whose ages were not disclosed but looked younger than ten, were trafficked from Burma to Thailand and forced into sexual slavery. Existing literature further indicates that there are approximately 200,000 child prostitutes in Thailand; 60,000 in the Philippines, 250,000 in Brazil and over 200,000 in the United States (Lukas, 1996). Most of these children suffer other physical abuses when they refuse to sleep with clients of the brothels.

From above, we observe that child labor exploitation takes various forms under different circumstances in many countries around the world. Exploitation of children's labor occurs in manufacturing sectors, in prostitution and within the household. Children's minority statuses increase their vulnerability to labor exploitation in all cases. As pointed out earlier, if children cannot sign contracts, open bank accounts but are allowed to work under certain terms, their parents and other adult members of their families are privileged to sign the minors to work under exploitative circumstances. Such working children may not be lucky to be the beneficiaries of the proceeds from their labor. 


\section{Child Domestic Servitude}

Child domestics are known in Haiti as restavecs (i.e. "staying with"), and vidomegon in Benin (International Labor Organization, 2001a). Until the 1980s, Ghanaians referred to the child domestic as "abaawa," which means servant. This name was replaced with others like maid, house-help, house-girls or maidservants because abaawa was considered derogatory. Given the focus of this research on domestic servitude, this section was separated from the previous in order that the literature on child domestic servitude, albeit insufficient, could be given more attention.

The ILO defines child domestic labor as "children working in an employer's house with or without a wage" (International Labor Organization, 2001a: 2; 2001b: vi). In the M.A. thesis, The Other Side of the Kitchen Door: Domestic Service in Lima, Peru, Elena Bee (1998) defines domestic services as "the many and varied types of work required to complete those duties pertaining to the maintenance, functioning, and day-to-day running of the household, particularly when performed by employed labor" (Bee, 1998: 1).

A distinction exists between domestic workers and domestic slaves. This distinction is based on the worker's age, number of hours worked, method of remuneration and if the pay is commensurate with the services provided (Derby, 2003). The domestic worker is a legitimate worker who is mature enough to understand the conditions of her employment. They are old enough to enter into contracts with their employers and can seek recourse through the law courts if unduly mistreated by their employers. Moreover, domestic workers exercise 
control over the ultimate decision to remain a service provider in the specific household (Derby, 2003).

Although some child domestic workers easily qualify as slaves, adult migrants are reported to work under slavery conditions as well. Like child slaves, migrant domestic workers work long hours, do not have control over themselves and are subjected to sexual abuses (Anderson, 2004).

The literature identifies two sources of recruitment for child domestic servitude. These are siblings or friends who are already working as domestic servants (UNICEF, 19999); other relatives and friends who might not be working as domestic servants and formal agencies of employment (Bee, 1998). For instance, in Peru where households have the option of using formal intermediaries or acquaintances, friends or maidservants of friends, they usually prefer getting their domestic servants through informal sources in order to avoid recruitment fee (Bee, 1998). Not all informal sources of recruitment are free though. As Bodo Ravololomanga and Bernard Schlemmer (2000) observe, parents whose children are recruited into domestic servitude in parts of Madagascar, as a rule, receive a certain sum of money when the child leaves home. After this, neither the children nor their employers are obligated to pay these parents.

Research shows that child domestics usually live in their employers' homes and work 10-18 hours a day, usually throughout the week and often without pay (SLIMG, 1997; UNICEF 1999; United Nation's Commission on Human Rights, 2002). Their day begins around 5 a.m. each morning (Kimaryo 
and Pouwels, 1999). They spend their entire time in their employers'

households, even when they are through with their chores (UNCEF, 1999). Their responsibilities include cleaning, laundry, food preparation, cooking, shopping and looking after young children (Shoishab, 1997).

Given the paucity of research on child domestic workers, it is not statistically known how many girls and boys have been enslaved in domestic servitude. Recent research estimates that Haiti has about 250,000 domestic slaves (Cadet, 1998; UNICEF, 1999); Dhaka in Bangladesh has about 300,000 child domestics; Jakarta, the capital of Indonesia has about 700,$000 ; 150,000$ in Lima, Peru and 766,000 in the Philippines (UNICEF 1999; United Nations Commission on Human Rights, 2002). It is estimated that $90 \%$ of domestic workers around the world are girls (UNICEF 1999; United Nations Commission on Human Rights, 2002).

Almost every country where the UNICEF conducted research on child domestic slaves has a cultural reason for the dominance of girls in household servitude. Girls are more likely to be deployed into domestic servitude because some cultures hold that girls would end up as housewives and so do not encourage girls' education (Mikay, 1997; UNICEF, 1999), and also because families consider their daughters to be thriftier and more appropriate to work outside the family to make money to support them (International Labor Organization and Inter-Parliamentary Union; 2002). This belief is based on the notion that girls neither smoke nor drink. In Togo where $95 \%$ of the child domestic servants are girls, it is considered strategic to use the girls' income to 
support the education of their brothers. In Bangladesh, restricting the girls to household chores is considered a means of protecting them, while in Nepal, girls are preferred to boys in domestic servitude because they are considered more submissive and are less likely to run away (UNICEF, 1999).

According to the UNICEF (1999), children between 10 and 14 years constitute $80 \%$ of all girls who work as domestics. In many countries, domestic servants are younger than 10 years old. In Dhaka, Bangladesh, for instance, $20 \%$ of the domestic workers are aged between 5 and 10 years. In Togo, $16 \%$ of domestic 'workers' are 10 years or less; $50 \%$ of them are under 14 and $65 \%$ under 15 years. Approximately $34 \%$ of the domestic servants in Uruguay started work before they were 14 years, while in Venezuela, 25\% of them are less than 10 years (UNICEF, 1999). Research shows that employers are more attracted to younger domestic servants because they are easily controlled and less expensive (ILO, 2001b).

Most of the domestic servants that the UNICEF and ILO researched were either never enrolled in school or were dropouts (Derby, 2003). The ILO holds that this is due to the fact that most of them are taken from their parents at very young ages. Research on Nepalese child domestic slaves found that $18 \%$ of them could neither read nor write; an estimated $10 \%$ of them could only write their names, while a little over $53 \%$ had received primary education. Nearly $18 \%$ were educated beyond the primary school and only 3 percent of the entire sample had some secondary education. This research further indicates that a majority (46\%) of boys and girls who work as domestic servants in Kathmandu, 
Nepal, are recruited through their relatives, while $16 \%$ of them are enrolled by their parents (ILO, 2001b). Employers recruit nearly 24\% of these child domestic servants. Friends recruit nearly $3 \%$ of them; brokers (agents) recruit $.3 \%$ while a little over $3 \%$ look for households themselves. According to this report, villagers recruit nearly $8 \%$ of the child domestic servants in Kathmandu. This report did not explain the relationship between the victims and these villages, and the role that they play in the recruitment of the children.

While in servitude, child domestics suffer physical and sexual abuses. An estimated $60 \%$ of Peruvian men who grew in households with child domestic servants confessed to having had their first sexual encounters with the latter (The United Nations Commission on Human Rights, 2002, UNICEF, 1999; Bee, 1998). In Fiji, $80 \%$ of the domestic workers are sexually abused (United Nations Commission on Human Rights, 2002). Ethiopian women and girls who are trafficked into Lebanon and Bahrain to work as domestic servants are reportedly raped and physically abused under debt-bondage (International Organization for Migration, 2000).

Whereas the distinction between negative and positive children's work sensitizes scholars to the socio-cultural context surrounding children's employment, that differentiation, as pointed out earlier in Chapter One, tends to be inadequate in helping scholars to conceptualize the overall impact of the exploitation of children's labor. As I observed in my M.A. thesis, a large number of children whose work qualifies as child labor usually work under slavery conditions (Derby, 2003). The kind of slavery that these children suffer is, 
however, different from the old forms of slavery. Theirs is a part of the new slavery (Bales, 1999; 2000).

\section{EFFORTS TO COMBAT CHILD LABOR EXPLOITATION}

There have been many local and international efforts to combat child labor exploitation. These efforts entail the adoption and ratification of international conventions that are enforced to protect women and children. Adopting and ratifying such conventions usually constitute the first steps on the part of a country to fight against the targeted form of exploitation. Although countries that sign and ratify international conventions have to conform to the standards and requirements stipulated in them, legislature in individual countries has not been able to enhance the eradication of child labor exploitation and slavery. While the international community has successfully created awareness among state governments about relevant treaties, there still needs a lot more to be done with grassroots' understanding of the extent of the phenomenon and existing laws.

Earlier in this chapter, some relevant conventions on the rights and protection of the child were mentioned. I examined the 1959 Declaration and the 1989 Convention on the Rights of the Child and how they conflicted with the Minimum Age Convention of 1973. Nevertheless, the ILO continues to enforce new conventions and to embark on revised strategies to aid in the pursuit of the elimination of child labor exploitation and slavery. Between 1995 and 2000, the 
ILO adopted eight fundamental conventions ${ }^{1}$. These are the forced labor conventions (Nos. 29 and 105), the freedom of association and collective bargaining Conventions (Nos. 87 and 98), the non-discrimination Conventions (Nos. 100 and 111), and the minimum age Convention (No. 138). The most recent fundamental convention, Convention No.182 focuses on the elimination of worst forms of child labor exploitation.

The Convention on the Worst Forms of Child Labor 1999 (\#182) transcends all other treaties by focusing specifically on the worst forms of child labor exploitation. First adopted in 1999, Convention 182 came into force in November 2000. The main goal of C182 is to bring to light the worst forms of child labor and to set the stage for their elimination. This convention observes children's vulnerability as the cause of their persistent of exploitation and abuses in some societies. It recognizes, further, that the problem of child labor exploitation can only be solved on a long-term basis in some societies, given the socio-economic and cultural backgrounds surrounding such exploitation. In accordance with these observations, worst forms of child labor were defined in Article 2 as:

- all forms of slavery or practices similar to slavery, such as the sale and trafficking of children, debt bondage and serfdom and forced or compulsory labor, including forced or compulsory recruitment of children for use in armed conflict;

- the use, procuring or offering of a child for prostitution, for the production of pornography or for pornographic performances;

\footnotetext{
${ }^{1}$ Available at $h$ ttp://www.ilo.org/public/english/standards/ipec/about/factsheet/fag.htm.
} 
- the use, procuring or offering of a child for illicit activities, in particular for the production and trafficking of drugs as defined in the relevant international treaties;

- work which, by its nature or the circumstances in which it is carried out, is likely to harm the health, safety or morals of children.

In order to achieve its main goal of eliminating the above forms of child labor, the convention called on member states to design and implement programs of action to eliminate the worst forms of child labor. States were mandated to take the effective steps to prevent the employment of children in the worst forms of child labor, provide the necessary and direct assistance to liberate and rehabilitate exploited children, ensure access to free basic education, and provide vocational training to liberated children.

In furtherance to Convention 182, the ILO launched a guide, the International Program for the Elimination of Child Labor (IPEC), to parliamentarians for the elimination of these worst forms of child labor. Launched in 1992, IPEC aims at working "towards the progressive elimination of child labor by strengthening national capacities to address child labor problems, and by creating a worldwide movement to combat it" $\left({ }^{2}\right)$. Primarily, IPEC is targeting bonded child workers, children who work under hazardous conditions and "children who are particularly vulnerable, i.e. very young working children (below 12 years of age, and working girls." IPEC works in cooperation and in partnership with governments, educational institutions, as well as employers and

\footnotetext{
${ }^{2}$ Available at http://www.ilo.org/public/english/standards/ipec/about/implemetation/ipec.htm.
} 
workers organizations. Its actions are based on a phased and multi-sectored

strategy that consists of

- Motivating a broad alliance of partners to acknowledge and act against child labor;

- Carrying out a situational analysis to find out about child labor problems in a country;

- Assisting with developing and implementing national policies on child labor problems;

- Strengthening existing organizations and setting up institutional mechanisms;

- Creating awareness on the problem nationwide, in communities and workplaces;

- Promoting the development and application of protective legislation;

- Supporting direct action with (potential) child workers for demonstration purposes;

- Replicating and expanding successful projects into the programs of partners; and

- Mainstreaming child labor issues into socio-economic policies programs and budgets .

A progress report on IPEC activities between 2000 and 2001 indicate that these steps and the main objective of IPEC contribute immensely to the main strategic goals of the $\mathrm{ILO}^{3}$. These are the promotion and realization of standards and fundamental principles and rights at work, the creation of opportunities for decent employment and income, the enhancement of coverage and effectiveness of social protection for all; and the strengthening of tripartism and

\footnotetext{
${ }^{3}$ Available at

http://www.ilo.org/public/english/standards/ipec/about/implementation/ipecreport.pdf.
} 
social development. This report further established a link between poverty and child labor exploitation. "It is now known that a vicious circle is in operation. Child labor hinders economic development and perpetuates poverty by keeping the children of the poor out of school and limiting their prospects for upward social mobility" ${ }^{4}$. In addition, this progress report asserts that child labor remains a major problem of child exploitation and abuse, thus depriving many children of education and health. It said most of the child victims are engaged in the worst forms of child labor abuse, slavery being mentioned as well as bonded labor, commercial sexual exploitation, armed conflict and domestic labor. Prominent among these are the conventions and the declarations that have so far been enforced.

Ghana has ratified 46 International Labor Conventions. The first Convention that it ratified is C1, the Hours of Work (Industry) Convention, 1919. This it did on June 19,1973, around the same time that the Minimum Age Convention came into force. Among other things, $\mathrm{C} 1$ requires a maximum of eight working hours a day, and up to 48 hours a week. Clearly missing on the list of Conventions that Ghana has ratified is the Minimum Age Convention. That notwithstanding, the minimum age for admission to employment in Ghana has been set at 15 years. A policy of Free Compulsory Universal Basic Education (FCUBE), which will be discussed in detail in Chapter Seven, has also been implemented, all in the effort to combat the exploitation of children's labor. The

\footnotetext{
${ }^{4}$ Available at

http://www illo.org/public/english/standards/ipec/about/implementation/ipecreport.pdf.
} 
most recent Convention that it ratified is C182, Worst Forms of Child Labor Convention 1999. Following the IPEC guide to this Convention, Ghana has embarked on a number of research and campaign to further its fight against the employment and exploitation of children's labor. Prominent among these are the Children's Act of 1998 (Act 560) and the Women and Juvenile Unit of the Ghana Police (WAJU).

In line with the CRC, Ghana's Act 560 promotes the interests of children and most importantly prohibits the deprivation of children, the right to live with their own parents and to grow up in a caring and peaceful environment. Part $V$ (Sections 87-104) of the Children's Act (1998) further provides legal guidelines for children's employment in Ghana. This Act sets the minimum working age at 15 (but set at 13 for light work) and prohibits the employment of children (which the act defines as all persons below 18 years) in exploitative labor and at night. Exploitation in this context refers to engagement of children in activities that deny them of health, education and development. This act prohibits the employment of children in all forms of hazardous occupations. Hazardous work includes going to sea, mining and quarrying, porterage of heavy loads, manufacturing industries where chemicals are produced or used, work in places where machines are used and in bars, hotels and places of entertainment where a person may be exposed to immoral behavior. Officials of District Assemblies and the Social Welfare and Community Development Departments of District Assemblies are responsible for ensuring compliance with these regulations. 
District Superintendent of Police (DSP) Comfort Boateng, head of the Women and Juvenile Unit of the Ghana Police (WAJU) indicated in my interview with her that this organization was established in 1998 in response to calls by the National Commission on Women and Development (NCWD), the African Women Lawyers Association (AWLA), UNICEF, International Federation of Women Lawyers (FIDA) and the Association of Market Women among other organizations to provide an avenue for solving and ending problems of sexual and physical abuses of women and children by men. WAJU is responsible for:

- Investigating all female and child related offences;

- handling cases of domestic violence, child abuse, juvenile offense and child delinquency;

- prosecuting all such cases where necessary; and

- any other functions as may be directed by the Inspector General of Police.

Cases reported to WAJU include defilement, rape, incest, abduction, assault/wife battery, child trafficking and "unnatural Carnal knowledge" DSP Boateng stated in her interview. When asked what percentage of the reports that the Unit receives involve abuses of child domestic servants, she stated that

"You know normally when a child is abused, sometimes it's by the help of an adult that the case is reported. In the case of the maidservant, unless people around the vicinity or the community or somebody we can call a patriotic person or some informant or somebody, a concerned person...they are the people who assist these, the maidservants or people to report cases, because the masters or mistress themselves... they are sometimes the abusers, and they will not bother to come to the police station to report their own selves. They don't come in, unless they are assisted by outsiders." 
While in Ghana, I saw many educational flyers or posters on WAJU. I also learnt from the DSP that they had embarked on educational campaigns through television and radio. At the premises of WAJU, there were many people who had brought cases of rape or other domestic violence when I paid a visit to interview DSP Boateng. Therefore, I would assume that many of these children are aware of the enormous help that awaits them at WAJU. What then, prevents exploited children in Ghana from utilizing the assistance that WAJU offers? Are they aware of the principles stipulated in the Children's Act of Ghana to protect them? Earlier, this chapter focused attention on criticisms of the CRC and the Minimum Age Convention. It is not only in that regard that efforts to eliminate child labor exploitation have come under fire. There seems to be a disconnection between governmental and non-governmental campaigns and the people most vulnerable for labor exploitation. As this dissertation will illustrate in Chapters Four through Eight, worsening poor conditions and living standards deterioration make it difficult for the government, its agencies and the many non-governmental organizations currently working together to protect these children to make any significant headway.

Berlan (2004) notes that intense poverty among the affected victims make it difficult to make any headway in the fight against child labor exploitation. As she suggests, the manifestation of poverty in child labor "requires sustained, long-term state investment and international support to improve education, road building and telecommunication, which would stimulate economic growth and reduce endemic poverty" (Berlan, 2004: 166). When a category of children is 
very poor and less educated, the gap between policy, advocacy and practice is heightened.

According to Berlan, this gap was demonstrated in Accra, Ghana where a big press conference was organized on June 12,2002 , to commemorate the World Day against Child Labor. There were representatives from the ILO, UNICEF and Children in Need, Ghana (CING). She observes that the information packs that the organizers distributed to children showed a disconnection between the targets of child labor exploitation and the campaigns against this phenomenon. She makes this comment about the information pack: I have yet to meet a child working in the rural sector in Ghana - which makes up over 70 per cent of all working children - who would be able to take any of these steps (167).

The information packs contained the following guidelines:

- Say no to work that is harmful and degrading to you

- Speak with people in your community about the problem and what can be done.

- Report cases of child exploitation to the authorities concerned.

- Learn more about child labor and the laws against it.

- Ask your government to ratify and fully implement the Convention on the Worst Forms of Child Labor.

- Write letters to the editors calling for immediate action to end the worst forms of child labour.

- Tell businesses that you will buy nothing from them if they exploit children.

- Call your friends together and form a group united against the problem. 
- Volunteer your time and support for organizations working to protect children.

- Pledge to continue your efforts until every child enjoys their right to a childhood.

As research on the Ghanaian rural child illustrates, a majority of them can neither read nor write. The discussion on Ghana's educational structure in Chapter Five will further throw light on the pattern of enrollment of children of school going age in Ghana. Given the lack of infrastructure and teachers in rural schools, low literacy rates exist among children who live in and go to school in the rural region. Statistics show that $60 \%$ of them do not acquire basic literacy (Berlan, 2004).

Another factor problematic with the above set of guidelines is the call on the children to ask the government of Ghana to ratify and to implement Convention 182. In the first place, the rural children do not know of any such Convention, have no idea about the existence of the UN and its subsidiaries and the ILO, and do not know of the Conventions that have been enforced to protect their rights and childhoods. It is for the same reasons that other activities by the Government of Ghana to secure the interests of its children have failed. There is also the fear of not knowing where they would live and who would take care of them if they defy their parents or caretakers and report them to the police, according to the Director of WAJU. Although this research did not evidence instances where domestic servants are made to accept domestic servitude under duress, my interviews with the Directors of WAJU and the Department of Social 
Welfare suggests that there are no official foster homes where abused children

could stay when taken away from their parents. She states when asked if they

had ever made an arrest about child labor exploitation,

"... You know may be the parent is the one who is trying to negotiate in such acts, and that child is still being cared for by that parent, so it is normally very difficult that we deal with such people, may be send them to court to face the law, the rigors of the law or whatever it is. After these parents have been dealt with, who takes care of the child? There is no, there has never been any preparation, the government has never made, how do I say it, any convenient place to keep the people, we don't have proper places to keep such people. Sometimes when they are taken to even the children's home, we are told that they can never accept them.

Some, of them they don't accept them, and even when they accept them, before they accept them you have to go the social workers' or social welfare office to demand some documents, a whole lot of it before even the child can be admitted at the children home. It is a very important thing that I have been asking the government or any agent to come out to help.

We observe from above that there are both national and international efforts to protect the Ghanaian child. Unfortunately, these efforts to protect them do not seem to be efficient - many Ghanaian children are overtly exploited through street work and petty trading. A major factor responsible for this is the disconnection between the realities that surround the vulnerability of children and the methods and processes of their protection. More importantly, these children are not aware of the existence of the many laws and institutions that exist to protect them. 


\section{CHAPTER SUMMARY AND CONCLUSION}

Efforts to combat child labor exploitation and slavery culminate in the proliferation of international treaties to safeguard the interest and care of children. Internationally, any person below the ages of 18 qualifies as a child. However, some scholars argue that this cutoff age impedes campaign against child labor because it is merely a Western political construct which does not conform to the realities of some cultures. Childhood in many traditional cultures is defined by a person's independence and lack of wealth. Many cultures require children to work not only to support the welfare of their families, but to be able to learn skills that would make them independent and productive members of society during adulthood. This coupled with the flexibilities inherent in conventions, such as C138 on Minimum Age, jeopardize children's labor. Today, as pointed out, 250 million children work under exploitative conditions. It is estimated that $41 \%$, i.e. about 80 million of all African children aged between 5 and 14 years are victims of child labor exploitation (African Business, 1998; Innocenti Research Center, 2002). Chapter Five will introduce the socio-cultural and economic environments within which children work in Ghana. 


\section{THE MAP OF GHANA ${ }^{5}$}

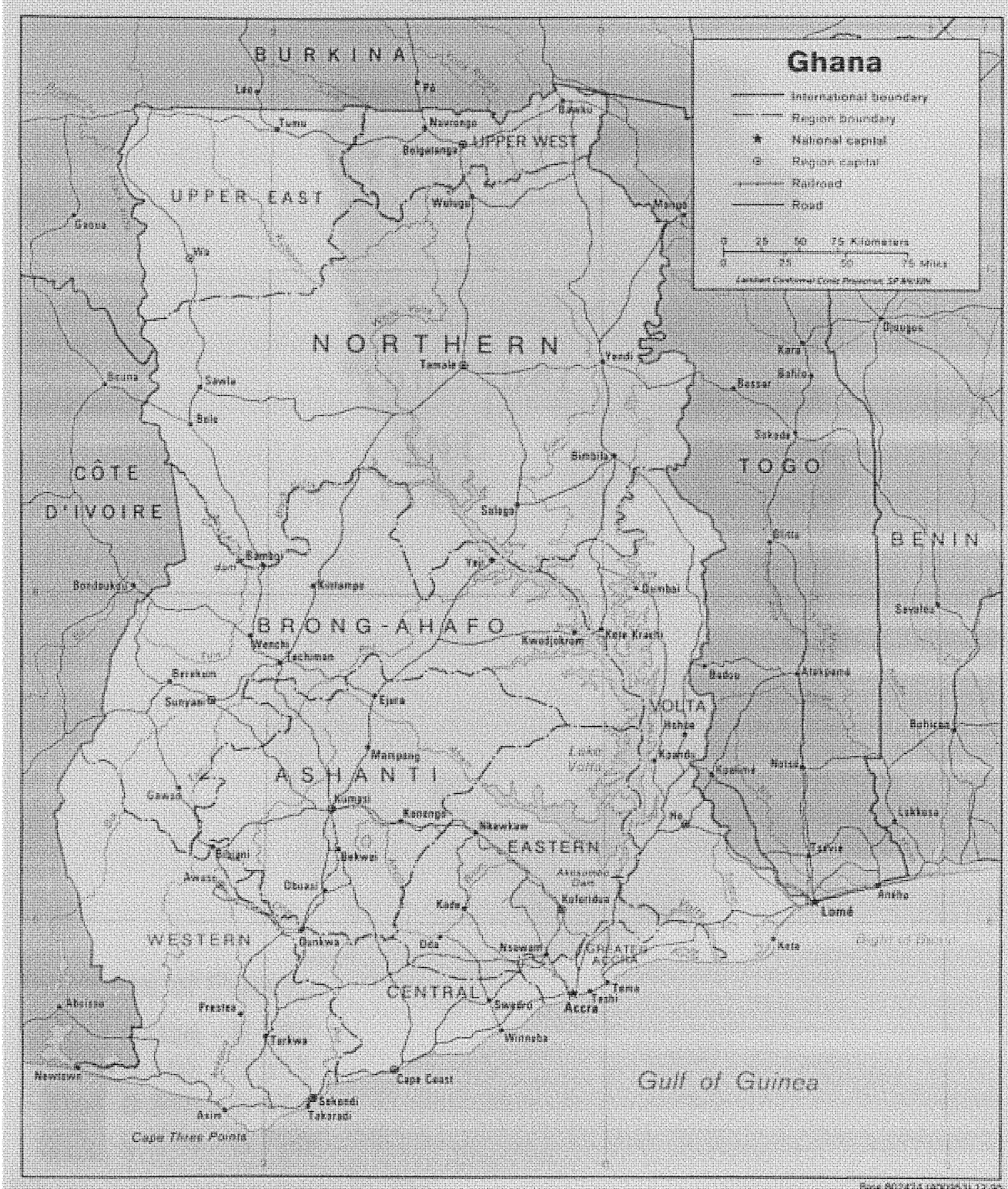




\section{INCIDENCE OF POVERTY IN}

GHANA - 1999

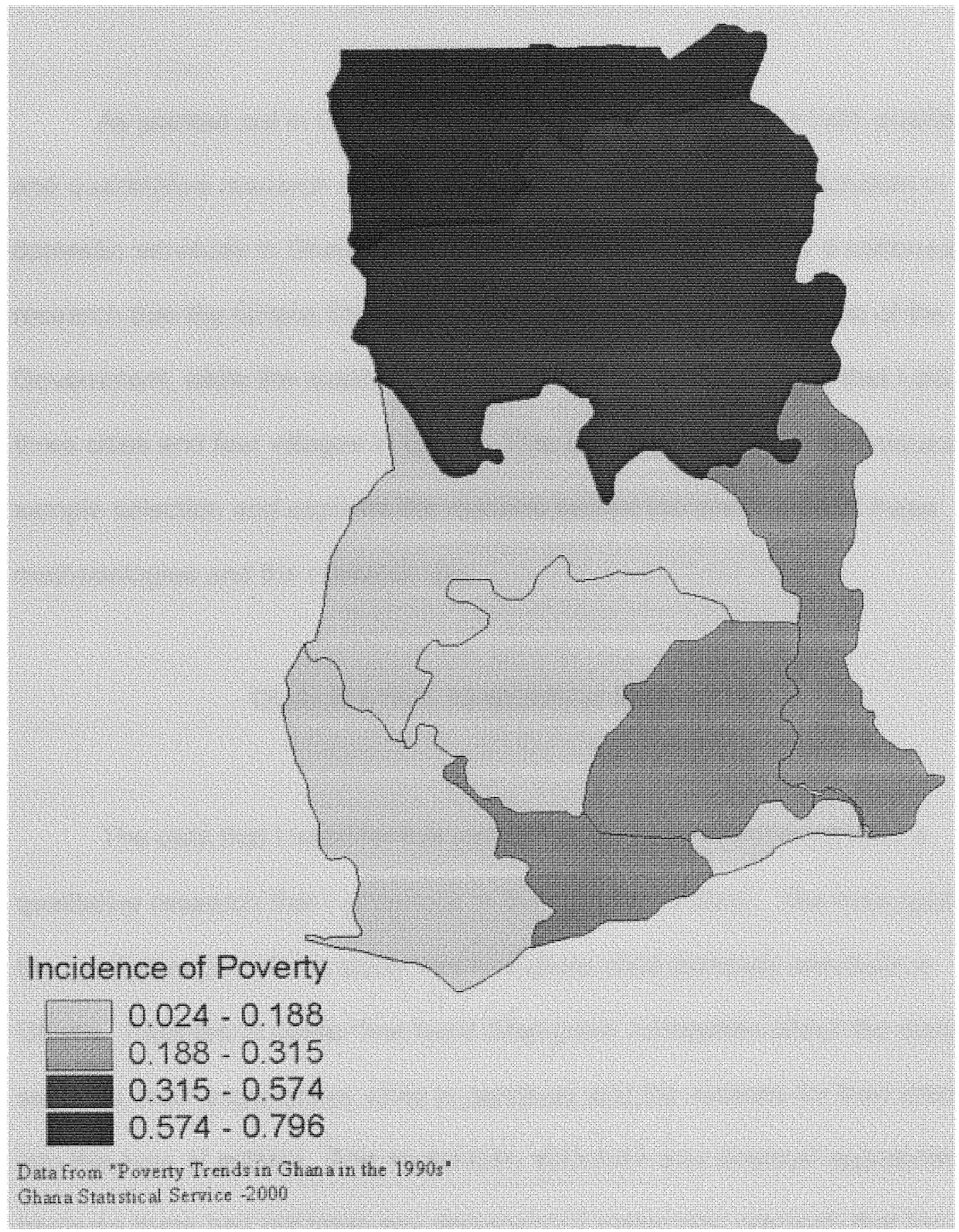




\section{CHAPTER THREE}

\section{RESEARCH METHODS}

As pointed out in Chapter One, this dissertation employs both qualitative and quantitative research methodologies to study child labor exploitation in domestic servitude in Ghana. The quantitative analyses employ a nationwide research that the Ghana Statistical Service conducted at the request of the Government, while the qualitative analyses derive from interviews that I did in three cities and four villages in Ghana. This chapter outlines the techniques of sample selection and explains the reasons behind the application of these methodologies and the research site.

\section{QUALITATIVE RESEARCH METHODS}

The data that I used for this part of the study were obtained from a qualitative research that I undertook in the summer of 2003. The main goal of the qualitative part of this study was to explore child domestic servitude in Ghana. I wanted to gather first hand descriptive information about the domestic servants, their experiences while in servitude and the reasons for their enrollment into this type of activity. This exploratory approach was deemed appropriate because there had not been any documented systematic research that focused specifically on Ghana's child domestic servants prior to this study. Their obscurity within the household setup also meant that they could not be subjected 
to any method of probabilistic sampling technique. Therefore, I had to begin the research through the qualitative approach.

\section{Research Sites}

Interviews were conducted in four rural, and three urban communities.

The four rural communities are Hwidiem in the Ashanti Region, Nankasido and Saltpond in the Central Region and Tikobo \#1 in the Western Region (see map on page 52). Although Tikobo \#1 and Saltpond are rural communities, I operationalized them as semi-rural in this dissertation because they have formal institutions such as banking, manufacturing firms and good schools. The three cities were Accra, the capital of Ghana and the Greater Accra Region, Cape Coast, the capital of Central Region and Kumasi, the capital of Ashanti Region.

A World Bank report estimates the population of Accra at 2.2 million (The World Bank Group, 2001). This accounts for about $25 \%$ of total urban population. As the capital of the country, Accra is home to Ghanaians from all ethnic backgrounds and to the head offices of major financial institutions, government institutions, parastatals and multinational corporations. It is the destination of many rural migrants most of whom confine themselves to the shantytowns along the edges of the city (Ghanaweb.com $\left.{ }^{6}\right)$. Accra boasts of Ghana's premier university, the University of Ghana (at Legon), and many new private universities. The best hotels and entertainment facilities are also concentrated in this city. Additionally, Accra and its neighbor of Tema, located

\footnotetext{
${ }^{6}$ This information is available at http://ghanaweb.com/GhanaHomePage/geography/accra.php.
} 
20 miles east of the former, have the largest number of the industries, both microenterprises and large plants, in Ghana (World Bank, 2001).

Kumasi is the second largest city in Ghana and is located approximately 250 kilometers northwest of Accra, the capital. It accounts for about $15 \%$ of total urban population in Ghana (World Bank, 2001). In 2000, a nationwide census estimated the population of Kumasi at about 1.7 million. Kumasi is the capital of Ashanti Region. Like Accra, it is destination to many rural migrants from the poorer regions of Northern, Upper East and Upper West as well as from rural areas in the Ashanti Region. Kumasi is home to the University of Science and Technology, a polytechnic, many vocational and training institutes and high schools.

Cape Coast, the third major town where I interviewed domestic servants, employers and a non-formal recruiter in this study, is the capital city of the Central Region. It is located along the Gulf Coast nearly 78 miles west of Accra. In terms of population, Cape Coast is not as huge as the other two cities. A 2000 nationwide census estimates its population at 82,291 . It is, however, considered the cradle of formal education in Ghana. It is home to the only University which for a long time specialized in research and the training of teachers, the University of Cape Coast where I received my baccalaureate degree. Most of the leading and elite high schools are located in this city. The leading role of Cape Coast in quality education derives from its status as the capital of the region where the first European missionaries and colonizers settled in the late $15^{\text {th }}$ century. 
Among its major tourist attractions is the Cape Coast Castle where a large number of West African slaves were kept and later shipped to the Americas.

Hwidiem is a very small village in Ashanti Region, located approximately 25 miles north of Kumasi, the Ashanti Regional capital. The 2000 nationwide census sets its population at about 340 . At the time of this research, Hwidiem was yet to be connected to the national electricity grid. It had no pipe borne water, and women and children had to walk at least one mile to fetch either spring water or water from a stream. Unlike other towns where I collected data from, this village had no marketplace. Some women took advantage of its location on the main trunk road that joins Kumasi and the district capital of Mampong to sell fruits, vegetables and tubers to motorists. At the center of the village, I saw a small kiosk in which a woman sold convenience items. As I will illustrate in the Chapter on education, Hwidiem has only one primary school. Students and pupils have to travel to nearby villages to go to continue with their education.

In the Western Region, I interviewed recruiters, current and former domestic servants and employers at Tikobo No. 1 and Bonyere. Bonyere is as poor as Hwidiem. The difference between the two villages lies in the fact that unlike Bonyere, Hwidiem is located on a major trunk road and thus is easily accessible. Tikobo \# 1, a bigger town, can boast of a private clinic, a rural bank and a Dutch owned coconut-fertilizer manufacturing factory. Tikobo No. 1 also has a private elementary school with grades one through the junior secondary school, and a public school with the same grades. 


\section{Sampling Techniques in the Qualitative Method}

Given the lack of reliable statistics and scholarly information on domestic servants, I could not employ any method of probabilistic sampling technique in this study. Additionally, I presumed that domestic servants would be afraid to talk to me, a stranger, while they are still in servitude. This fear, I thought, would be alleviated if I contacted them in the company of someone that they knew; or if they were convinced an acquaintance or family member sent me to them. I further assumed it would be impossible to be granted permission to interview a domestic if I went through their employers. In view of this, I considered the snowball sampling technique to be most appropriate in this research.

In addition, I selected the convenience sampling technique to supplement the snowball sampling. This was due to the fact that I believed domestic servants were easily identifiable by people who have encountered them before; and from the fear that employers would not allow interviews with their servants. I anticipated that the supplementary use of convenient sampling technique would enhance access to domestic servants outside their homes for interview appointments. While this approach worked in terms of getting domestic servants to talk to without always having to go through the snowball technique, the reality about employers, on the other hand, turned out to be different. Most of them were permissive of interviews with their domestic servants. Some of them went a step further to grant me interviews themselves.

As someone who had lived with and encountered domestic servants among the research population, I considered myself a mere informed researcher 
whose status augmented the use of the two non-probabilistic sampling techniques mentioned above. As regards the snowball technique, I knew a priori where and how to approach domestic servants in the early stage of the fieldwork. My application of the convenient sampling technique was also possible because I could identify domestic servants when they have not been introduced to me as such.

I was aware of where to locate my respondents. One could see them in schools, in the streets, on the markets and in churches. What engage them in these locations also isolate them from all other children. I knew, for instance, that domestic servants took their employers children to school in the mornings and went for them late in the afternoons. At the market place or at shopping centers, domestic servants either sell or buy foodstuffs for the households they live with (Shoishab, 1997). On many occasions, they go in the company of their employers and carry the wares on their heads while they walk from stall to stall. At church, if the employing households have young children, the domestic servant takes care of them by changing and feeding them. She is usually dressed differently from the rest of the children in the family, and does not usually look cheerful especially if in the company of the employers themselves.

Given this background knowledge, occasionally during this research, I went to schools around the times that domestic servants come there so I could interview them. The maidservants either carry the children on their back if the latter were very young, or just walked them, at times, holding their hands. This approach of convenient sampling technique was not successful - employers 
were still home when domestic servants sent their children to school, and were expecting them back within a specified period. Therefore, the girls turned down the request to be interviewed for fear that they would be late returning home and could be punished. Only one girl, about 10 years old, agreed that I accompanied her to seek permission from her madam. Having had employers who were so permissive of me and even volunteered to participate in this research, 1 accompanied this child, thinking that her employer was not going to be different from the others. Contrary to my expectations, she refused the interview.

In that particular incident, the girl was somewhat hesitant when I first approached her. However, when she understood the purpose of my interview, she agreed, but asked me to come home with her since her madam expected her back within a specific period. The walk to her house took about six minutes. It was a two-storey roadside building that towered the rest of the houses along the road. But for the dust which emanated from passing vehicles and covered mostly the base of this building, the house looked newly constructed and very prominent. A high wall bordered the building, making it difficult for pedestrians to see its inner features on the lower floor. My would-have-been respondent rang a doorbell, and her madam came to open us, after about a minute. We exchanged greetings and I explained my mission to her. She reluctantly permitted me into the building. Inside, there were two vehicles, one of which was an old Mercedes Benz. An American flag hang on the Mercedes, so I presumed either the entire family or the woman's husband had lived or lives in America. The domestic servant went inside to take off the child on her back. She brought me a seat and 
we started the interview. A minute into the interview, however, an unpleasant madam returned from the main building to ask that I stopped the interview because they had a doctor's appointment. I apologized, thanked her and asked if it was okay for me to be back. She was not sure because she did not know when they were going to be home. I figured she was never going to allow the interview, and so did not return.

Ten of the respondents at Accra were selected through the approach of convenient sampling technique outlined above. Through the snowball approach, such respondents helped me to identify other domestic servants. One of the domestic servants whom I identified through this approach and who helped to get other servants to talk to is Mansah. When I met her, she had a big gallon that seemed heavy because of the way she tilted towards one side, in hand. I asked her a few preliminary questions and confirmed that she was indeed a domestic servant. She had arrived at Accra, less than a month earlier, to work for an Accra-based petty trader whose name she did not even know. She was one of many girls who worked for this woman. Like other domestic servants, she expressed her fears about being seen with me. She was also afraid that if she stayed longer than it usually took her to run that particular errand, she would probably be punished.

I therefore made an appointment with her for the next morning. I did tell her about my intentions to interview her as well as the purpose of that interview. True to her word, she came back the next morning for our interview. She promised to help me interview other servants in that household, but I could not 
follow her to these other girls. On the second day, she came back to my house, in the company of a younger domestic servant, thirteen years old at the time of the interview. I nicknamed her Selasie. Selasie had been living with their employer for about nine to 11 years. Although Mansah promised to bring more domestic servants, I never saw her again. I could not follow the address to look for her because of my promise to her that I would not get her into trouble with her employer.

Tikobo No. 1 is the other town where I had to use the convenient sampling technique. In this town, I went to the main shopping area, also the market place and got two shopkeepers who were domestic servants. Through them, I was able to talk to an employer, two recruiters and four more domestic servants.

\section{The Sample}

I interviewed 86 respondents. Apart from two government officials who participated in this study, I assigned fictitious names to each one of my respondents. Most of the 86 respondents were identified through the snowball sampling technique, while the rest were selected through convenience sampling technique. I approached respondents at shops, near schools where I suspected they would be dropping off or picking their employers' children, or simply knocked and entered homes in some of the elite neighborhoods to look for potential respondents. There were 44 current domestic servants, 14 former domestic servants, seven parents, six agents of recruitment, two government officials and 13 employers. 
The current domestic servants had either dropped out of school, or had just graduated from the J.S.S. There were 16 current domestic servants who had dropped out of school, while 18 had completed the J.S.S. Three of them were still in school. Seven current domestic servants never went to school. The oldest person in this sample was a 28 year old woman whom I met at one of the two employment agencies that I will be discussing shortly. She was also the only domestic servant respondent who had completed the senior secondary school (S.S.S.). The second oldest person was 25 years old and was recruited at the age of 15. She had dropped out of school. Three of my respondents were recruited around the age of six. However, at the time of this research, the youngest person was 8 . There were four other participants who were as young as 12 . The rest were aged between 13 and 20 .

I interviewed 14 former domestic servants in various communities in Ashanti, Central and Western Regions. I categorized them into older cohorts of domestic servants who lived in other households prior to Ghana's implementation of neo-liberal economic policies in the 1980 s, and younger cohorts who were recruited afterwards. There were six former domestic servants who worked in other households before the 1980 s and eight others who worked afterwards. All six respondents among the older generation, at some point, were given the chance to go to school; however, only one of them remained there until the end of the primary school.

Esther, the only semi-educated among the six older cohorts of domestic servants, was also the only respondent in this category who could tell me her age 
and the exact year of her enrollment into domestic servitude. The rest found it difficult making references to exact timelines. They did not know their current ages or when they were enrolled into domestic servitude. Born in 1955, Esther accepted to live with a nurse who was looking for a babysitter while the latter migrated to the city to further her education. At the time, Esther was 11 years old. When I met her for this interview in 2003 , she was a housewife. The others had become petty traders or fishmongers.

A majority of these participants belonged to the Akan ethnic groups, consisting of Ashanti from the Ashanti Region, Nzema/Ahanta from the Western Region, Fante from the Central Region and Akuapim from the Eastern Region. With the exception of the Akuapim, all these Akan ethnic groups are matrilineal. Among the Akuapim, one observes both matrilineal and patrilineal systems of ancestry. People from all the northernmost regions of Ghana practice patrilineal systems. These include the Kusasi in the Upper East Region and the Dagomba in the Northern Region.

\section{Semi-Structured Interviews}

The qualitative interviews were semi-structured, which asked mostly openended questions. These questions related to the subjects' working conditions and experience as domestic servants, the structures of the households they come from, processes of recruitment, and the economy of their households. The questions also enquired about the domestic servants' level of autonomy; and the factors that lead parents to send their children into domestic servitude. 
As regards the servants' working conditions and experiences, I wanted to know how long domestic servants work per day, if they are abused and what forms such abuses take, if they are paid and the forms such remunerations take. I asked almost all the respondents if any arrangements were made about the type and method of remuneration at the time of their enrollment into servitude. Prior to the fieldwork, I was aware that most of the domestic servants in Ghana are not paid at all. However, some of them are provided the means to learn a trade after staying with their employers for some years. Employers give their domestic servants sewing machines and or pay their starting fees for them to enroll in an apprenticeship in hairdressing or dressmaking. In the event that the child escapes for inability to endure abuses and long hours of work, or if they are sent back to their parents for truancy or unsatisfactory performance, they might not gain anything at all. If they are paid in cash, I wanted to know who the primary beneficiary of that income is.

This research also investigated the level of autonomy that the child domestic servant exercises over her or his employment, the incomes or remunerations accruing to him or her, and her or his ability to exit servitude whenever she or he deems appropriate. The literature on child labor and child slavery points to scholars' identification of victim's level of autonomy as an important explanatory factor of new forms of slavery. In defining sexual slavery, for instance, Barry (1984) highlights the significance of autonomy when she argues that slavery exists in "ALL situations where women or girls cannot change the immediate conditions of their existence; where regardless of how they got 
into those conditions they cannot get out; and where they are subject to sexual violence and exploitation" (Barry, 1984: 39-40). In a more recent publication, Kevin Bales $(2000,1999)$ identifies subjection of the victims to violent control and the loss of their freewill as the major defining factors of slavery. Given these views on contemporary slavery and prior research and interpretations of old forms of slavery, I was interested in finding out if these child domestic servants could exercise the level of autonomy that disqualifies them as contemporary slavery.

Additionally, I wanted to know if the domestic servants that I interviewed in this research were slaves. More specifically, I wanted to know if they freely accepted or volunteered to work for their employers. For that reason, questions relating to the level of autonomy delved into the processes through which they were recruited, negotiations of their working conditions, processes of their exit from servitude and how their incomes were disbursed. I was interested in finding out if participants could voluntarily leave the job without creating any problem between them and their parents or family members on one hand, or between their families and their employers on the other.

This dissertation further investigated the impact of gender roles and expectations on child domestic servitude. That women and girls spend more hours providing services in the private domestic sphere has long been established. I, however, asked parents whose children work or worked as domestic servants and the employers themselves if they had any sex preference in the recruitment of children into domestic servitude and what reasons they had 
for their preference. Additionally, I asked parents which of the sexes they were more likely to enroll into domestic servitude and why that was their choice.

\section{Qualitative Data Analyses}

Given the partial influence of interpretative sociology on this research, I collected the data having in mind that the respondents, rather than I, are the experts in their lives and the meanings that they attach to their experiences as domestic servants. I adopted this approach to analyses from Anne Kasper's A Feminist, Qualitative Methodology: A Study of Women with Breast Cancer (1994). Kasper used the interpretative approach in that study and saw the respondents as the experts of their lives and the meanings that their lives had for them and their beliefs. She identified herself as an informed researcher and developed a three part approach to the data analyses. In the first part, Kasper sought to recognize and to capture the meanings and understandings that the respondents shared about their breast cancer crisis. In the second and third parts, Kasper's position as an informed researcher came into play. She looked for "the connections between facts and meanings presented in an individual's account..." to "...uncover how events and meanings..."were related to overarching themes in each of her respondents' crisis (276), and to link individual accounts to the other respondents. In the third stage, she focused on the relationship between the general themes discovered in the previous stages to the study's theoretical framework. 
Following that approach, I developed a three stage methodology in the analyses of the qualitative data. I devoted the first stage of my analyses to the meanings that respondents have about their positions as past or current domestic servants, a parent of a domestic servant or an employer. In the second stage, I connected events such as the death of a parent, the death of an employer or a parents' childhood experience and the understandings that respondents shared about their lives. Given that my respondents were heterogeneous because they occupied different positions either as past or present domestic servants, paid or unpaid workers, parents or employers, I had to draw links within homogenous groups and at the next stage, see how they related to the other groups. Within the same homogenous group, I compared individual accounts to the rest of their group members. In the last stage of the qualitative analyses, I located the generally observed patterns in the theoretical framework and formulated the hypothesis for the quantitative analyses.

\section{QUANTITATIVE METHODS EMPLOYED IN THIS STUDY}

Chapter Two in this dissertation outlines some domestic and international efforts to eradicate child labor exploitation. Among them is ILO's International Program on the Elimination of Child Labor (IPEC), which is a guide to the organization's Convention on the Elimination of the Worst Forms of Child Labor (C182). IPEC primarily aims at the progressive elimination of child labor. Within 
the framework of this program, ILO endeavors to assist with the development and implementation of national policies on issues related to child labor, help create national awareness of problems associated with the incidence of child labor, and to promote the development and application of protective legislation in party states, among many other objectives some of which were mentioned in Chapter Two. Following these objectives of IPEC, the Ghana Statistical Service, in the early 1990s, did a pilot study on street children in the country. Based on the findings and the need for the country to build a databank on the incidence of child labor exploitation to facilitate efforts to eradicate this phenomenon, the Government requested a more comprehensive research on child labor exploitation. Consequently in January 2001, the Ghana Statistical Services, in collaboration with the Ministry of Employment and Social Welfare, undertook a more comprehensive household-based survey. As indicated earlier, I employed the data from that research for the quantitative analyses in this dissertation.

The quantitative analyses were carried out in three stages. The first stage examined univariate distribution of dependent and independent variables for the child workers in this study. Both dependent and independent variables were mostly categorical. Therefore, the second stage of the analyses tested the existence of bivariate associations among relevant variables, using chi square statistics. In the third stage, logistics regression analyses were performed on dummy dependent variables. Some of the dependent variables for the logistics regression analyses were obtained from transformation of variables that had more than two categories. The following subsections outline the univariate 
analyses. The rest of the quantitative analyses will the qualitative analyses of the relevant relationships among variables.

\section{Univariate Distribution of Dependent and Independent Variables}

The findings of the qualitative analyses informed variable selection for the quantitative analyses. I observed from the interviews that lineage, education, sex and respondents' origins are some of the variables that influence child domestic servitude in Ghana. Unfortunately, not all patterns of dependent and independent variable relationships that the qualitative analyses evidenced could be subjected to statistical analyses given the nature of the statistical data that the dissertation employed.

There were 17,034 respondents who were made up of $8,871(52 \%)$ males and $8,163(48 \%)$ females aged between five and 17 years old. The average age is 10.6 with a modal and median age of 10 years respectively. The standard deviation of the mean is 3.58 . Table I provides the age distribution in detail.

Table II is a presentation of the regional distribution of all respondents in the survey. The largest proportion of respondents, 2,623 constituting $15.4 \%$ of the sample came from the Ashanti Region. The next largest proportion of $14 \%$ came from the Northern Region. Respondents from the two smallest regions of Upper East and Upper West provided 1,027 (6\%) and 773 (4.5) respectively. The rest of the regional distribution of the sample is presented in the Table. 


\begin{tabular}{crr}
\hline & Frequency & Percentage \\
\hline 5 & 1,291 & 7.6 \\
6 & 1,485 & 8.7 \\
7 & 1,536 & 9.0 \\
9 & 1,451 & 8.5 \\
10 & 1,357 & 8.0 \\
11 & 1,598 & 9.4 \\
12 & 1,150 & 6.8 \\
13 & 1,546 & 9.1 \\
14 & 1,246 & 7.3 \\
15 & 1,197 & 7.0 \\
16 & 1,370 & 8.0 \\
17 & 994 & 5.8 \\
Total & 813 & 4.8 \\
\hline
\end{tabular}

OPERATIONALIZING CHILD DOMESTIC SERVITUDE

The data obtained from the Ghana Statistical Service does not define the variable of child domestic servants or servitude. Therefore, using the variables of "relationship to the head of household" and "employment status", this dissertation operationalized child domestic servants to consist of all unpaid family workers or domestic servants below the ages of 18 , who are not the heads of their 
households, and who do not live with their parents, spouses, in-laws or siblings. In other words, "child domestic servants" in the quantitative part of this dissertation refers to those who describe their employers or household heads as non-relatives or other relatives. This definition derives from my observation from the qualitative interviews that domestic servants combine trading and household responsibilities and at times define their employers as relatives, but could not specify the nature of the relationship.

Table II: Regional Distribution of the Sample

Frequency

Percentage

$\begin{array}{lrr}\text { Western } & 1,724 & 10.1 \\ \text { Central } & 1,396 & 8.2 \\ \text { Greater Accra } & 2,009 & 11.8 \\ \text { Volta } & 1,372 & 8.1 \\ \text { Eastern } & 1,951 & 11.5 \\ \text { Ashanti } & 2,623 & 15.4 \\ \text { Brong Ahafo } & 1,765 & 10.4 \\ \text { Northern } & 2,394 & 14.1 \\ \text { Upper East } & 1,027 & 6.0 \\ \text { Upper West } & 773 & 4.5 \\ \text { Total } & 17,034 & 100.0\end{array}$

Table III provides frequency distribution of respondents' relationships to their household heads. Response categories to this variable are "head," 
"spouse," "child," "brother/sister," "grandchild," "son/daughter-in-law," "other relatives" and "non-relatives." We observe in that table that a large number of respondents are the children of the household heads. While such children may be engaged in some type of economic activities, what they enjoy which distinguish them from other child workers is the love and support they easily access by living with their families.

Table III: Respondents' Relationship to their Heads of Household

Frequency

Head

Spouse (husband/wife)

Child

Brother/sister

Grandchild

Son/daughter -in-law

Other relative

Non-relative

Total
3

15

3,161

233

2,083

32

1,258

249

17,034

\section{Percentage}

.0

.1

77.3

1.4

12.2

.2

7.4

1.5

100.0

Table IV and $V$ show two new variables I recoded from the variable of "relationship to the head of household". The first is the new variable of "child workers" which excludes household heads, spouses, brothers/sisters and son/daughter-in-laws, but includes children/grandchildren of domestic servants, other relatives and non-relatives. Table IV, which is a distribution of the new 
variable of "child workers," indicates that $91 \%$ of all the children in the survey are grandchildren or children of the head of the household. Table $V$ is a repetition of Table IV, but excludes the first response category of grandchild/child. We notice that 1507 respondents are the domestic servants. They are children who live with people they define as other relatives or non-relatives, and are engaged in various types of unpaid work, prominent among them being the provision of domestic services.

\section{Table IV: Distribution of Child Workers}

$\begin{array}{lrc} & \text { Frequency } & \text { Percentage } \\ \text { Grandchild/Child } & 15,244 & 91.0 \\ \text { Other relatives } & 1,258 & 7.5 \\ \text { Non-relatives } & 249 & 1.5 \\ \text { Total } & 16,751 & 100.0\end{array}$

\section{Table V: Distribution of Child Servants}

Frequency Percentage

Other relatives

1,258

249

Non-relatives

Total
83.5

16.5

100.0

The other variable which aided the operationalization of the "child servants" (or domestic servant) variable is respondents' occupation, whose frequency distributions are provided in Table VI. Out of the sample of 17,034 
respondents, 4,788 cases were valid for the computation of frequency distribution of employment statuses. An insignificant number of these respondents, i.e. three in all, were employers themselves. While only 38 respondents indicated that they were domestic servants, a crosstabulation of respondents' relationship to the head of household and employment status revealed that 1,500 could be operationalized as domestic servants.

Table VI: Employment Status of the Sample

$\begin{array}{lcc} & \text { Frequency } & \text { Percentage } \\ \text { Employer } & 3 & .0 \\ \text { Employee (full-time) } & 26 & .2 \\ \text { Employee (part-time) } & 25 & .1 \\ \text { Casual employee } & 70 & .4 \\ \text { Own account worker } & 414 & 2.4 \\ \text { Unpaid family worker } & 4,098 & 24.1 \\ \text { Domestic Employee } & 38 & .2 \\ \text { Paid apprentice } & 10 & .1 \\ \text { Unpaid apprentice } & 104 & .6 \\ \text { Total } & 4,788 & 100.0\end{array}$

\section{CHAPTER SUMMARY AND CONCLUSION}

The methodologies that I employed in this study were primarily qualitative and exploratory. The lack of existing research on child domestic servitude in general and Ghana's domestic servants in particular made me choose these 
methods. Given that surveys in previous research on child labor did not successfully explore child domestic servitude, I used the snowball and convenience sampling techniques in order to gain access to the domestic servants. These approaches required that I started the interviews in areas where I was sure I could get domestic servants to participate in the research without they being afraid of punishment from their employers. 


\section{CHAPTER FOUR}

\section{PROCESSES OF RECRUITMENT AND THE NATURE OF RELATIONSHIPS BETWEEN DOMESTIC SERVANTS AND THEIR EMPLOYERS}

The previous chapter outlines the methodologies of the qualitative and quantitative data analyses. The qualitative research consists of five different samples. These are current domestic servants, former domestic servants, parents of domestic servants and employers and recruiters of domestic servants. In this and the following chapters, I discuss the interviews that I had with respondents in these different samples. Although households either patronize the services of domestic servants or serve as the source of supply of child domestic servants for economic reasons, traditional practices of reciprocity and familial relationships are, in some cases, tied to the recruitment of children into some type of domestic servitude.

This chapter focuses on the processes of recruitment and the role of families in the recruitment of their members into servitude. Given that urban regions tend to be more attractive, parents either look for urban households for their children to live with, or accept offers presented to them by recruiters. Children who graduate from the basic education and do not have any hopes of continuing or learning a trade if they remain in their households also look for and or accept offers of domestic servitude. In this research, I discovered three vital approaches through which children are recruited into domestic servitude. I refer 
to them as formal, non-formal and informal processes of recruitment respectively. I discuss these three approaches of recruitment in the following subsections.

\section{RURAL VERSUS URBAN FAMILY STRUCTURES AND THEIR INFLUENCE ON THE RECRUITMENT OF CHILDREN INTO DOMESTIC SERVITUDE}

In Chapters Six and Seven, I will analyze the Ghanaian rural parents' poor socioeconomic backgrounds and how these impact the vulnerability of their children to labor exploitation. Among others, I argue in those chapters that although there is poverty in urban Ghana, its prevalence does not deny children from relatively poor families access to formal education because of the standard of and availability of teachers and infrastructure in urban public schools. Given the attractiveness of urban schools, children are less likely to drop out and to become vulnerable to labor exploitation. This section discusses the direct involvement of the family in the recruitment of their children into domestic servitude and draws a distinction between rural households from where domestic servants originate and urban households that employ the servants.

Parents and families influence the recruitment of their young children into domestic servitude in so many ways. In the first place, their occupational backgrounds may enhance their abilities to keep their children in șchool, and thus protect them from exploitative child labor. In the second place, the amount of authority that parents and families exercise over their young children or relatives can impact the vulnerability of the latter in labor exploitation. 
Interviews with parents and unobtrusive questions included in my interviews with the children pointed to the influence of parental occupation on children's vulnerability to labor exploitation and slavery. On one hand, parents' occupation can generate enough income that will make it possible for families to finance their children's formal education. On the other hand, parents' occupation can thwart a child's education by inducting them into the occupation in question while denying them the chance to concentrate all their time and energy on formal education.

Some cultures require both boys and girls to enter the labor market as part of their socialization processes. In the population of study, the type of training that a child receives during socialization tends to be culturally and geographically specific. Different geographic areas in Ghana specialize in different economic activities; and this has historically determined what children learn through informal socialization. Among rural Ashantis and the populations of other forest areas in Ghana, for instance, boys and girls learn gender related farming skills before they become adults. Girls are made to learn how to use the hoe to clear weeds from farms, to gather forage or uproot tubers while the boys focus on clearing the land for farming. Back home, both boys and girls go to fetch water from the streams and rivers. The girl's day will not end there - she will continue running errands to assist her mother prepare the evening meals and to clean after that. The boys will spend time interacting with male adults of their households. 
I also observed that the amount of control that children have over themselves was important in their recruitment. In both rural and urban households, children have limited autonomy over their lives. Following Western legal traditions that I discussed earlier, children in former colonies in SubSaharan Africa cannot sign contracts, open bank accounts, access courts or accept job offers (Ramanathan, 2000; Landsdown, 1994). Traditional expectations of children in the research population take these attributes of minors to a different level.

In Ghana, children are less powerful relative to adult members of their households. Both traditional patterns of socialization and formal educational texts socialize Ghanaian children to acknowledge and internalize the superiority of adults by respecting and obeying them (Berlan, 2004). The popular adage that children must be seen rather than heard make it less likely for them to question decision made on their behalf by other members of their households. Parents and adults, in general, have utmost authority over children. This gives adults in the child's immediate, as well as their extended families, the decisionmaking power over them. As I observed with the recruitment of Akosua, one of the respondents in this research, both extended and nuclear family members came together to negotiate with the university professor who recruited her.

Both current and former domestic servants indicated that their parents were the decision makers as far as their statuses as domestic servants were concerned. The only difference I observed in this regard is the fact that a majority of contemporary domestic servants were old enough to decide with their 
parents regarding their employment into domestic servitude, while the older generation of servants were relatively younger and had no say whatsoever when their parents sent them away. Five of the six older cohorts of domestic servants said their parents made decisions about their recruitment and work for other families. Only one former domestic servant from the pre-1980 era, Esther, was different from the other older participants. Esther voluntarily and willingly decided to look for somebody to live with when she had a misunderstanding with her maternal grandmother. She lived with more than one family, and unlike the other respondents in her generation, received partial pay for her services, in some cases, while one family promised her the usual sewing machine.

Responses by the other domestic servants in this regard included: "they gave birth to me so I had to come," "I had finished school and wasn't doing anything so I wanted to come," I was always wishing that I could get somewhere to go since I was basically idle," and I didn't like going to the farms so much so it was a great opportunity for me to leave the village."

In view of the above, the decision or not for a child to enroll into domestic servitude depends significantly on the position of adult family members. All but seven of my domestic servant samples agreed that their parents or guardians had the final say in their work as domestic servants. They stated further that it was a sign of respect to obey their parents under such conditions. In one particular case, a parent demonstrated his authority over his domestic servant daughter by emphasizing that if the daughter, Esi, who had been sending messages to her parents about the abuses she was experiencing returned home 
today, he was going to send her back the next day. He asserted in his conversation with me that as the father, he had absolute control over his child and whatever he said was final.

Samira's experience is typical in this case. When she left her stepgrandmother for maltreatment, she could have stayed with her own mother or grandmother to remain in school. However, her younger sister who was living with her mother's aunt had ran away to her father's village, also for abuses. Samira was given to this grandaunt in place of her younger sister so that the relationship between her mother and her extended family members would not be mired. Her mother insisted that Samira lived with this relative.

Domestic servants are usually recruited from rural regions for urban households. Rural families usually live in overcrowded buildings that house different households. Often, these are extended families in which grand and great-grandmothers, uncles and aunts as well as cousins pool and share resources together. The crowding pertaining to rural areas in Ghana is also present in urban communities. There are compound houses that are occupied by households which in most cases are made up of extended families. These are poor families which do not have domestic servants. Where such households live with domestic servants, the latter are recruited primarily for petty trading purposes. Mansah and Selasie who were mentioned in Chapter Three and Serena lived with such families at Accra. The first two families that Samira lived with also bore these attributes. 
Employing households, on the other hand, are almost always economically comfortable, with at least one of the parents occupying high ranking positions in a state or private organization. In this research, there were university professors, high school teachers, government officials and self employed business men and women who hired the domestic servants. There were one air hostess and one Member of Parliament.

Unlike their counterparts in rural households or among the urban poor, employing households have between one and four children. This makes it easier for them to reduce overcrowding in rooms, and to be able to ensure that the children receive the highest level of education that they would want to attain. In about six households, I found out that the employers' children lived in either Europe or North America. There were other adult children of employers who lived in other parts of the country. If young children were not home at the time of this research, they were usually living in boarding houses as students.

In some cases, children whose parents are otherwise well off end up in domestic servitude upon the death of their parents and in the absence of an honest successor to take care of the orphans. Although it is rare for urban poor to find themselves in domestic servitude, instances of extended family members succeeding and usurping the properties of the deceased drive some urban children to live in servitude. In this research, I interviewed three domestic servants who ended up in domestic servitude under similar circumstances. Two of them were sisters who lived part of their childhood as domestic servants because their uncle who inherited their deceased father's timber factory failed to 
take care of them. Although their mother did not live in a village, she could not afford to take care of all four children.

Although a majority of my respondents moved from rural areas to urban centers, a number of them had moved from rural to rural, rural to semi-urban or from semi-urban to semi-urban areas. The processes of recruitment my interviews reported did not differ much between rural-semi-urban and rural-urban employments. Limited observations indicate that the rural-rural recruitment was markedly different from the other two. I interviewed only one former domestic servant who lived with her father's friend in a rural community to attend school in a nearby village. During my visit to this village, I observed that a number of households lived with distant relatives and at times with people that they were not related to in any way. Nevertheless, children who find themselves in such situations are given the opportunity to attend school, and to enjoy their childhood - at least within the rural context - this being significantly different from the outgroup positions that domestic servants in urban areas endured.

\section{PROCESSES OF RECRUITMENT}

This research discovered three patterns of recruitment of domestic servants. In none of these three processes of recruitment did I observe the use of force to recruit the servants, although underage children are not adequately knowledgeable and mature enough to consent to their enrollment. In the following subsections, I discuss the three types of recruiters I found under each 
pattern. There is a significance difference between the processes of recruitment for girls who were employed between 1980 and 2003 on one hand, and those who were recruited in the years before. Cultural practices and beliefs influenced the recruitment of older domestic servants, therefore, both close and distant family members were those who arranged to either live with younger relatives or to send them to other relatives.

\section{Formal Recruiters}

These are formal employment agencies which specialize in the recruitment of domestic workers, house-boys, garden-boys and cooks. Formal employment agencies have not always existed in Ghana; they are a recent development in the country of research. The first such organization was established in the early 1970s. My informant, a chief and brother of the founder of this organization, could not give the exact date of establishment because it became defunct on the death of the founder. This foundation concentrated on the recruitment, training and assignment of domestic servants who were old enough to work. The late sister, a Canadian trained nurse, decided to found this organization in order to help curb the abuses and exploitation that young women and girls had to endure in domestic servitude. I learnt while collecting the data that there were five such organizations, but I was able to locate two of them for interview. 
Domestic Services Agency at Dansoman. While introducing myself

to a domestic servant's employer for the permission to allow the interview, she launched into her own complaints which eventually made her a respondent. It was in the course of this interview that I learnt about the first formal agency. I made a call to the director and got an appointment for the next day. This was a home-based office, located on a very busy road connecting Dansoman, a somewhat affluent suburb of Accra where his business is, to the administrative centers and other parts of the capital city. Behind his small office in the same house lies a stretch of lawn in the middle of which stood an avocado pear tree. It was under this tree that we conducted the over one hour long interview.

He had an office assistant, the only employee in this organization. Prospective domestic servants have to submit an application plus a fee, which at the time of this study was $C 15,000.00$ (approximately $\$ 2.00$ ). The agency further requires a police report on applicants, and for that, prospective domestic servants have to pay an additional fee of $C 30,000.00$. Besides personal information and contacts, applicants need to provide two guarantors who can be police officers, clergymen, military personnel or civil servants. The average age of applicants is 21 , with the minimum being 18 . Usually, prospective employees just walk in, looking for jobs. When this agency runs short of applicants, they send word through their recruits to contact relatives or friends who could be looking for jobs.

Clients looking for domestic servants have to register with the agency. They pay a 665,000 "retainer fee," which, according to the director, goes towards 
the background search of prospective servants. How much domestic servants earn depends on what the employer is willing to pay. Employers also pay an equivalent of a month's salary to the agency. In 2003 , monthly salaries ranged between 100,000 and 200,000 cedis, which is about US $\$ 15-30$. Clients who offer the lowest pay of $C 100,000$ per month agree to provide toiletries, food and clothing until the end of the employees' service. When approved, employees . who go through the agency have to sign a contract. If violated, they forfeit a month's salary.

Domestic servants may encounter problems ranging from culture shock through communication problems. As the director pointed out, his recruits made complaints like

"... not sleeping early; things like they are not able to... to have an off day somewhere along the line... and then things like people who have been exposed to a kind of life where they've always, like you are exposed to people outside, it becomes a bit difficult for them to live in an enclosed environment whereby you cannot go in and come in as you want... and things like may be not communica...communication problem, not understanding each other, it could be from a language barrier where you get the client and the domestic help not really speaking the same language and then you, may be English is the medium of communication where the domestic help is not very good at that language..."

Domestic Services Agency at Tesano. While driving through the streets of Tesano, a major affluent community at Accra one morning, I came across the billboard for this agency. When I went in, I was able to talk to the director and two applicants. There were at least ten applicants who waited on pews either to submit new applications, to come for training, or to follow up on 
previous applications. Among them was a male who appeared to be in his late 30 s to early 40 s. He told me he came to apply for a job as a houseboy or a gardener. Almost all the females there appeared to be in their 20 s or were older than that. There was an 18-year-old woman who had migrated from the northern part of the country in search of a job. She lived with her brother's family, but did not get along with his wife and so was looking for another place to go and stay. She hoped she would get a live-in employment where she could stay. She was a school dropout.

The second respondent from this agency is the 28-year-old woman earlier mentioned. She lost both parents and could no longer fund her education. She therefore decided to look for a job. She heard about this organization through a friend. If given employment, this would be her third job through this agency. She lived with the first employer for about a year. She received $\$ 300,000$ until this employer returned to Nigeria where she came from. She got her second job through this agency, but the employer was not as generous as the former. She said that this employer, although a Nigerian too, had cultivated the "Ghanaian employer's habit of being mean." The employer had promised to pay her C200,000, but started her on 100,000 and refused to increase it. In addition, she did not permit this respondent and other household employees in her house to eat or make personal use of the resources available. As a result, she terminated her contract to look for another employer.

The recruitment process was the same for this agency as the one at Dansoman. Applicants had to pay a registration fee and another for background 
check. Prospective employers also bore a percentage of the fee for background check.

As would soon be illustrated, the processes of recruitment under these two formal agencies of employment differed markedly from non-formal and informal agents of recruitment. Their concern about the age of recruits and households in which these recruits would work created a safe environment for both employer and employee. Formal agencies protect their clients by ensuring that their recruits do not have any criminal background. The provision of training for new recruits prepare them for their prospective households and provide them with the tools that would help them work satisfactorily while preparing them against physical and sexual abuses. Another important trait which was nonexistent among the non-formal and informal recruits was the negotiations that formal agencies held with clients on behalf of their recruits in order to ensure that the latter got regular remuneration commensurate of the services provided.

\section{Informal Recruiters}

More often than not, urban residents who visit rural regions of the research population are met with repeated requests from parents to take one or two rural children with them to the cities. Even before I entered college, I had about two children, a boy and a girl, whom I had been approached to live with the moment I got out of school and became independent. Also, while in college, residents in the villages where I collected data for my undergraduate research, or worked as a research assistant, requested that I came for their children to live 
with once I graduated. In one such instance, a local interviewer that I supervised told me his daughter was ready to move to live with me on campus, if only I would say yes to their request. More recently when I went to Ghana for this research, there were at least two such proposals. Both requests came from two women in one of the villages that I visited. One of them was a middle aged looking woman, probably in her 30 s, who asked me to help her migrate to the United States. She was prepared to do anything that I asked her to, even to become a prostitute, in exchange. When I returned to the same village a week later to interview parents of former domestic servants, a mother, a respondent, also made a passionate plea to me to send at least one of her daughters with me. She also did not care if I would let them become prostitutes. Such approaches by parents and prospective domestic servants constitute the first type of informal recruitment. In the other type, prospective servants or their families are approached by relatives or non-relatives.

Informal recruiters are the extreme opposites of the formal recruiting agencies. They are the occasional intermediaries between prospective domestic servants and their employers; and are neither registered nor regular recruiters. I identified three different types of informal recruiting. The first type involves family members who assist relatives to either recruit or to become domestic servants. The second type involves non-family members, while the third is a combination of both family and non-family members. It is in the first category that parents who are eager to let their children - both school going and non-school going - migrate to the cities to benefit from the many amenities that the city offers fall. The 
experiences that I shared in the previous paragraph typify the ways in which families try to look for employers for their children. Parents approach close and distant relatives as well as non-relatives when they cannot finance their children's education, or when they want them to migrate to the cities.

Esi, the last of six children, for instance, finished the J.S.S. at age 15 when her father had proceeded on retirement. Both parents were no longer on any substantial source of income and so could not fund her through the senior secondary school (S.S.S.). Given this background, her mother approached this respondent's employer, requesting that Esi lived with them and provided free domestic services for which she would be given a sewing machine and the apprenticeship fee at the end of two years. Such instances were commonplace in this study. What was unique about Esi's situation was the fact that when her mother was a child, she lived with the employer's mother too. Throughout my interview with Esi's parents, her mother referred to Esi's employer as her own sister, and so would not pay any mind to complaints that the daughter had sent to them prior to my appearance. As tradition demands, Esi's father acknowledged his wife's professed relationship to her childhood employer's daughter by referring to the latter as his "wife" too.

Circumstances surrounding Serwah's recruitment depicts another approach through which family members participate in the recruitment processes of domestic servants. She comes from the same village as her employer's. This employer's aunt, a teacher in that village, served as recruiter for her nieces in the cities. This teacher approached her one afternoon and asked if she was still in 
school. She had dropped out and was actually looking for a place to move to when the teacher spoke to her. She showed interest in going to live with the teacher's niece, a secondary school teacher and from there, this recruiter went to see Serwah's mother who also agreed.

An example of non-family member recruitment was Angela's. This current domestic servant lost both parents by age 12. Her uncle looked for someone for her to live with but she had to quit after nine months for wrongful accusations, abuses and threats to send her back without pay. She returned to her grandmother in the village. There, a former domestic servant who had had to return home for getting pregnant while a domestic servant recruited her. This recruiter pleaded with Angela's "father" (the uncle who succeeded her deceased father) and grandmother to permit her employment because "... she didn't want..." Angela ... "to mess up" her "... life, get pregnant and loiter about aimlessly...," Angela explained. I asked Angela how her life was going to be better than her recruiter's since the latter got pregnant while in servitude and she stated, "You should realize that if I live with my "father" and my grandmother, I won't be obedient to them. But when you live with different people, you have to listen to what they say before you can live with them." Angela said that she did not want to accept the offer initially because of her previous experience. However, she decided to do it after her uncle's persuasion.

The third type of informal recruitment is depicted in Akosua's employment in which her family members and a non-relative initiated her recruitment. Akosua's uncle became the main intermediary between her family and her 
employer, although the whole recruitment process originated from a current domestic servant who came from her hometown and was working in Cape Coast where Akosua was to go. The elders of her extended family held discussions prior to the arrival of her employers, a university professor and his wife, a university staff. In attendance were her mother, maternal grandmother, her mother's uncles and brothers. Her father was deceased at the time of her recruitment. She could not attend that meeting because "they are the elders," she said. She was close to 18 years when she was employed, and could have participated in the negotiations. However, given that many Ghanaian households adhere to the notion that the "child could only be seen and not heard," she left the negotiations to her older family members.

Akosua's uncle disclosed proceedings at the meeting to her:

"When they came, the family asked what type of work I would be doing. And they said I would be doing housework, and no other work. We were told they would pay me 80 [80,000 cedis], and my uncles said it wasn't enough. They [the employers] said I was going to be their responsibility, if I fell ill, it was their responsibility, my cream was their responsibility, my soap was their responsibility, my meals were their responsibility, everything was their responsibility, but if I were to do my hair, then that would be my only responsibility. But I wanted to do my hair but my mother and the others said they won't let me do it."

Such was the strength of this extended family's influence on Akosua that when asked if she was able to do her hair, she stated

"... They asked me to go and cut it so I went in the company of a certain sister to go and cut it. When I finished..., when we were going, my mother told us that we shouldn't cut it too short. But they made it so short so when she saw it, she was like why did you sit down for them to cut it so short? I asked her not to bother me since she was the one who asked me to go and cut it." 
All in all, these processes depict the families' and friends' eagerness to

assist their young relatives and friends to migrate to the cities and towns to escape the harshness of village lives and to take advantage of the many amenities available in the cities. As Michel Bonnet notes,

In an environment marked by large numbers of young people out of work and an education system offering members of the poorest parts of society, particularly in the Third World, virtually no chance at all of finding work, hunger pangs go hand in hand with the fear that children are about to fall victim to the worst of all possible ills ... Parents are tormented by worries for their children's future. All they want is to give their children the very best of what they have to offer - and what invaluable experience they have of the struggle to survive! - to equip the for life and, in short, help them develop, they hope, towards the longest possible future (Bonnet: 2000: 182183).

This observation corroborates earlier research finding in other countries that parents did not only want their children to migrate to the cities for absolute poverty, but for relative poverty as well (Ramanathan, 2000). While relative poverty refers to the lack of life threatening resources such as food, health and shelter, relative poverty is concerned with taken-for-granted resources such as access to luxuries and in this particular context, to the amenities in the cities.

\section{Non-Formal Recruiters}

Although different from the two other types of recruitment, non-formal agents exhibit traits of both formal and informal recruiters. They are regular recruiters who, although not formally established as agents of employment, bring children from rural areas to other places to live with and work for other families. Like the informal processes of recruitment, they employ children of all ages, 
making these domestic servants most vulnerable to various forms of abuses and exploitation. I was able to interview four non-formal recruiters who had employed some of my respondents. I interviewed the first (nicknamed Derrick) at Accra. I met the second (nicknamed Sophia), a housewife who petty-trades in foodstuffs in front of their university bungalow, at the University of Cape Coast. Her husband works in a middle-level managerial position at the University.

I met the third non-formal recruiter (nicknamed Ali) in a semi-urban area at Tikobo \#1 in the Western Region. An employer directed me to his shop where he sold canned foods and other convenient products. From Tikobo \# 1, I went to a nearby village, Bonyere, where I interviewed the fourth non-formal recruiter (nicknamed Ahmed). In the following subsections, I give detailed accounts of my interviews with these non-formal recruiters.

Derrick: The Non-Formal Recruiter at Accra. I met three of Derrick's recruits but could interview only two of them. They were two girls and a boy. I interviewed the boy and one of the girls. All three of them had finished the junior secondary school (J.S.S.). The male lived with the female I could not interview in the same household. In that household was another male servant whose relative was the household head. It was during my interview with the male respondent that I learnt about this agent and took the directions to his house. A combination of the very poor and somewhat rich lived in that part of Accra.

Sometime in 1985, Derrick's employer and owner of his current house, a university professor whose wife was a medical doctor, asked him to look for a 
domestic servant from his hometown for him. This family had an only child and needed someone who would help around the house and keep their daughter company. Following that recruitment, the professor's friends and acquaintances always approach him to look for a helper or garden boy for them, although women dominated. Derrick emphasized that his recruits work for only university faculty and staff, however, the three that I encountered worked for businessmen. I also learnt from his interview that at least one of them lived with a high school administrator. According to him, in 2003 when I conducted this research, he had recruited between 45 and 50 domestic servants and houseboys since 1985 .

Most of his recruits are aged between 15 and 20 years. He usually brought them from his hometown in the Central Region or his wife's hometown in the Eastern Region. Two of the recruits came from his hometown, while the other was his wife's sister. Usually, Derrick's recruits completed the junior secondary school before he employed them and so were at least 15 years old. He told me that

"The people I bring them to ... are [university] lecturers who always speak English. The person who dropped out of school will have problems with the language, the language could be a problem but those who finished the J.S.S. could express themselves."

Contrary to this assertion, although the three recruits that I met had finished the J.S.S., they could not speak English. This was characteristic of most children who lived and went to school in rural Ghana.

Derrick looked for recruits for his elite clients. Nevertheless, parents do approach him whenever he visits his hometown asking him to look for jobs or 
people for their children to live with in the cities. Michael is the male recruit that I

interviewed. He had finished the J.S.S. and was neither going to school nor working when Derrick visited his hometown. Michael's mother is friends with Derrick's sister and on this visit, the mother pleaded with him to find a job for her son. In response, Derrick said

"... He didn't have any job for me. However, he was going to look for someone for me to live with so that I would be paid at the end of the month. He said I would save that income and when I got enough to go and learn a trade, I would ask permission to leave..." Michael explained.

In explaining to me why they were willing to migrate with him to the cities,

Derrick stated that in their

"Village, for instance, we see vehicles like once a week. I know some girls that I brought here sometime ago and if you saw them, you might not believe she had even lived in a village. The way they talked, dressed and their mannerisms had all changed. So they prefer to come to the cities to get polished or to learn."

He further stated that

"Pregnancy rates are higher in the rural area than here. In all the ten years or fifteen years that I have been bringing children here, none of them has become pregnant. Most of the time, they live in a walled house and even where there is no security, you can't go out without being noticed. In the villages, however, the girls could just say they are visiting their friends and would be back soon, but might be going to see their men. So it is helpful when they come to the cities. There is another girl that I brought here eight years ago. All her peers have become pregnant or have given birth, but she is here and hasn't become pregnant. Her mother is therefore happy 1 got her out of the village."

Kate, one of the two females recruited by Derrick, was also his sister-in-

law. At the time of this research, Kate had curtailed her "contract" with her first employer and had come to Derrick to be reassigned to another family. Kate's 
previous recruitment did not follow that pattern of parents approaching him for assistance with their children. She had finished school and was not working in her hometown when Derrick visited and asked "If I would like to go and live in Accra? I said yes, but asked him what I will be doing there? His response was that he would know what to do with me when we got there. His wife is my sister. He told my mother before bringing me," Kate explained. She stayed for one year and decided to leave because her employer's aunt who also lived in that house maltreated her. At the time of her recruitment, Derrick arranged that the employer paid her off with a sewing machine, a trunk or a suitcase filled with pieces of cloth at the end of two years. Given her early curtailment of this arrangement, she received only $C 300,000$, i.e. a little less than US $\$ 40.00$, for the entire year that she lived with and served that family. Derrick kept it for her while she waited to be reassigned.

Kate was not the only person among Derrick's recruits to have prematurely ended a "contract." They encounter a number of problems that drive them to quit, some without informing their employers. I learnt through an employer that her husband sexually harassed some of the girls that Derrick brought to them. On a number of occasions, they ran away. However, Derrick kept sending female recruits into this particular house. A couple of months after returning from Ghana, I found out that the other servant whom I could not interview had run away. She had made complaints about her employer's sexual harassment. Soon afterwards, Michael, the only male among Derrick's recruits who lived with this other girl, also escaped because his employer thought he had 
encouraged and assisted the female servant to escape. Prior to my departure, I spoke to Derrick about these allegations of sexual harassments. He denied those associated with this particular household, but discussed another instance where a servant made similar complaints and how he removed the girl from that household.

Like the other intermediaries in this research, Derrick acted as a surrogate parent for his recruits. He cited instances where his girls or boys living in neighboring households usually pass by to say hello when they went out to run errands. He told me that he also visited them from time to time to see how they are doing. When asked if he receives pay for his services, he responded in the negative. He only received compensation or refunds when he uses his own money to go for recruits. As to whether parents get paid when their children are taken away from them, he pointed out

"That the parents at times expect that after a year, they should be given part of their children's money. Some of the parents that the children live with do understand when I explain it to them, that it is they who gave birth to the children and so could give may be 200,000 to be given to the parents. There are those who argue that they were supposed to take care of their children. They failed to do that and I am taking care of them so I have nothing to give them. So there are two things. There are those who understand, and those who will never understand."

Kate stated in her interview that Derrick once took money from her former employer for her mother. Derrick did not make the request for her mother to be paid. "Bro. Derrrick said my mother extended her regards to me. She [employer] asked if he went to my mother and he said yes. Then she said that when he was leaving she would give him something to be given to my mother," Kate said. 


\section{Sophia: The Non-Formal Recruiter at the University of Cape}

Coast. I met this recruiter, Sophia, through a domestic servant at the University of Cape Coast. As mentioned already, she is a housewife whose husband occupies a mid-level managerial position at the University. She was in her sixth year of recruiting. Like Derrick, Sophia started recruiting children when a neighbor at the university requested a child from her. Her recruits came from her hometown. They were usually aged between 12 and 17 years old. I figured her recruits could even be younger, because she considered those aged 14 to be old. When I met Sophia, she did not decline the interview; however, she was reluctant to provide information regarding her position as a non-formal recruiter, claiming that she had employed only one domestic servant for a family at the university. As the interview progressed, she contradicted herself by making references to other domestic servants that she had recruited for university employees. Like other non-formal recruiters, Sophia was afraid I could be a government investigator about the exploitation of children's labor.

Her recruits had not always completed the J.S.S. Some had dropped out of school. Sophia usually arranges with employers to either pay her recruits regularly every month or to give them the accumulated wages at the end of an agreed period. Although she could not tell how many girls she had brought to live with other families, I could tell that she had a very high rate of turnover. The longest staying domestic servant spent about a year. Two sisters that she recruited for two different families received $C 80,000$ and $C 50,000$ respectively per month. Sophia kept the money for them. The sister who received 50,000 
had to leave for misunderstandings with the employer. Her employer was

dissatisfied with her and so made complaints to Sophia. Around the same time, that particular recruit went to Sophia to express her displeasure with her employer and subsequently was assigned another employer. I never got her to talk to. However, Sophia said that recruit received a total of 450,000 cedis for living in that household for nine months. She took 150,000 for personal effects and gave the rest to Sophia to save for her. Sophia never got remunerated for recruiting duties, but at times received reimbursement for transportation from the employers.

Ali: The Non-Formal Recruiter at Tikobo \#1. Ali and Ahmed are the other two recruiters that I spoke to. They both came from the northern part of the country. These two recruiters shared a unique attribute that Sophia and Derrick did not have. Ali and Ahmed were former recruits themselves and based on their community's perception of them, have become role models and consequently, recruiters. Ali migrated to the south through a non-formal recruiter, who was also a northerner. He could not recall the exact year he was recruited; however, he had lived in the southern part of Ghana for over 20 years. Before 2003, he used to buy coffee from neighboring villages; he did not indicate where he sold it, but I assume in the Côte d'lvoire. Ali recalled the circumstances leading to his own migration to the south to justify his current "pastime" as a recruiter:

"Life was very difficult in the north. Besides, some of the children live in the villages there. Life tends to be difficult for the people there. Their parents can't make earns meet. However, there are some job openings here. For those children who are out of school, life could be very difficult for the children. When we go home- 
those of us who live here in the South and have some sources of income - when you go, their parents could ask you to bring them with you because they might not be able to take care of the children. They would ask you to go with their children and look for somebody for them to live with so that they, when they go back, they may have acquired a few belongings that would make them look good. That's why we bring them when we go."

Ali did not start recruiting because a neighbor or friend requested him to. Rather, parents wanted him to help their children migrate to the South to look for jobs and to learn some skills. Like the other non-formal recruiters, he did not charge for his recruiting services. However, employers were at times responsible for his travel expenses. What he did which differentiated him from the other nonformal recruiters was his habit of occasionally giving money to the parents of his recruits, not as payment for buying the children, but as a way of sympathizing with them, he emphasized. As I understood, he only wanted to be generous towards them. Such parents still maintained the right to go for their children whenever they wanted.

At the time of the interview, he had been a recruiter for about 10 years. He travels to the north at least once every year and brings no less than two children with him on every visit. The youngest of his recruits was employed at 10. Most of them, he told me, were at least 12 years old. The average number of years that they remain continuously in servitude was between two and three years. Like Derrick and Sophia, his recruits look up to him as a surrogate parent. They report their problems to him. He usually mediates between recruits and their employers and transfers them to other employers if he deemed that necessary. 


\section{Ahmed: The Non-Formal Recruiter at Bonyere. Ahmed also came}

to the south in search of a job through a former recruit. He works as a watchman and farmer at Bonyere, which was even more rural than Tikobo \#1. He was particularly scared of the interview. As a result, when he finally met me -1 had visited the village twice without meeting him on previous occasions - he walked me two to three miles to his employer's house to introduce me to them, and to give them the chance to assess me. I had no idea why we had to meet his employers until we got there. The male employer was not available. I spoke to his wife about my research. This woman called her son, a high school drop-out, to talk to me and to evaluate the truth in what I had told them about me and the research. Some of Ali's responses had alerted me to the possibility of some recruiters refusing to answer my questions or to grant the interview because of the fear that I could be a government investigator. Therefore, I showed him my business card in an attempt to convince him that I was not working for the Government of Ghana.

Looking at the expression on the boy's face, I assumed he would not recommend that Ahmed gave the interview. Therefore, I thanked them for their time and set out to leave. A couple of minutes later, I saw Ahmed running after me. He had been given the go-ahead to grant the interview. He explained to me that he was not only concerned about himself, but about my safety too. Three strangers had been killed three weeks earlier and under circumstances that were similar to my visit, he told me. He went to indicate that another stranger who had requested the assistance of a small girl lured her to the outskirts of the village 
and had her killed. The next day when the girl's body was found, parts of it had been cut off, possibly for voodoo rituals.

I spoke to one servant that Ahmed recruited. She was manning a convenience store at the market at Tikobo \#1. This recruit, Hawa, could not tell me her age, but looked younger than 10 . Her employer told me she was eight and had been living with her as a domestic servant for two years, two months. Ahmed is her paternal uncle. This particular girl's employer had asked around for domestic servants and was directed to Ahmed. Usually, Ahmed would have taken money for transportation to go to the North for a child. However, his brother, Hawa's father, who had already migrated to Ashanti Region in the south, was also looking for an employer for this child. Hawa was thus sent to live with her current employer at Tikobo \#1. It was through Hawa and her employer that I located Ahmed.

Ahmed confirmed he had recruited two girls for his employer. While waiting for him on my first visit, I learnt from his child that he had brought two children with him the last time he went home a couple of months earlier. Like Ali and the other non-formal recruiters, Ahmed told me he never got paid for his services as a recruiter and also remained constantly in touch with his recruits.

All four non-formal recruiters told me that they were happy to help both domestic servants and the employing households. There was no way I could prove them wrong. However, I observed that Derrick, on his part, derived some level of satisfaction and pride being an associate of the elite households that he recruited children for. His statements about the backgrounds of his clients and 
the way parents approached him whenever he visited his hometown, a village, probably put him on a pedestal that surpassed any monetary benefits that he would gain if they were to pay him for his recruiting duties. Ali and Ahmed did not know each other although they both came from the northernmost part of the country and lived 10 minutes drive from each other. Nevertheless, their explanations of why they brought children from their villages corroborated each other's statements. They told me in separate interviews that their concerns about the poor children in their respective hometowns drove them to become recruiters.

While all these non-formal agents of recruitments played the role of surrogate parents, voluntarily recruited children for employers and hardly received any pay for their services, I observed some significant differences between Ahmed and Ali's recruits on one hand, and those of Derrick's and Sophia's on the other. Unlike Derrick and Sophia, Ali's and Ahmed's recruits live in less developed towns. They mostly live with petty traders who do not need them to work only around the house, but to hawk and keep their small shops for them. Although one of Sophia's recruits sold pastries for her employer, a teacher whose husband taught at the University of Cape Coast, it is not as prevalent in the major cities as they are in the semi-urban communities.

Another difference is the educational backgrounds and economic positions of the employers who live with these recruits. Whereas employers at Tikobo \#1 and Bonyere are primarily semi-educated or uneducated low income earners who live off petty trading, those at Accra and Cape Coast that Derrick and Sophia 
served are highly educated university professors and businessmen who have better economic standing and social class than Ali's clients.

I also observed a low turnover among Ali's and Ahmed's recruits. One factor probably responsible for this is the cultural backgrounds of these recruits and their similarities with their destinations. Ahmed and Ali recruit boys and girls from the North. I observed that the servants from the Northern part of the country are more committed and subservient than the rest of the respondents. Northern Ghanaians are considered most subservient among all the tribal groups in Ghana. As we observe from Map II on the incidence of poverty in Ghana, the three northern regions, i.e. Northern Region, Upper East and Upper West Regions are the poorest. Given their desperation to escape severe levels of poverty, therefore, it is easier for them to tolerate those abuses characteristic of domestic servitude in general, which the girls from the south cannot endure for long.

Another factor is the similarities between their hometowns and the villages that they serve in. As the poorest regions in the country, the northern part of Ghana is the least developed and thus exhibit much of the rural attributes that characterize Tikobo \#1 and Bonyere. Among these characteristics is the level of individualism that domestic servants at Accra, Kumasi and Cape Coast encounter. In the villages, these domestic servants experience what Sociologist Emile Durkheim characterize as mechanical solidarity. Everybody knows each other. In times of need, individuals are able to rely on fellow villagers for assistance without immediate reciprocal exchanges. They live like one big 
family. Life in the cities is the direct opposite. Nobody seems to care about each other unless personal relationships have been established. Domestic servants cannot be friendly to everybody that they meet, and thus feel like they are living in cages. Some recruits to Accra, Cape Coast or Kumasi complain of the quiet and individualistic nature of their neighborhoods and abrogate their contracts as a result.

The third factor is the lack of competitiveness in the rural areas. In the village and semi-urban communities, servants feel more at home. This coupled with the communal nature of the less individualistic nature of the rural communities that they are recruited into make it easy for them to stay longer than in the cities.

To sum up this discussion on the processes of recruitment, it is worthy to note that whatever means through which servants are recruited, the probability of staying in touch with one's own family or recruiter is higher than not. Out of the 58 current and former domestic servants interviewed, only three of them could not remain in touch with either their family members or recruiters. Two of the three servants, Selasie and Molly who were recruited between the ages of two and three, and so could not recall how to locate their families. Selasie was still in servitude at the time of this research. At 13 years, she had stayed in servitude for at least 10 years and so knew nothing about her own family. Molly got the chance to be with her mother a few years after servitude and after a couple of visits, was not allowed to go back to servitude. The third servant is Claudia. She 
was old enough to identify her parents, except that she did not know how to get to her house at Tema, a metropolitan town located near Accra.

\section{NATURE AND STRUCTURE OF RELATIONSHIPS BETWEEN EMPLOYERS AND DOMESTIC SERVANTS}

In the previous sub-sections, I described the role that relative and nonrelative recruiters play in the employment processes of domestic servants. A major observation that I made from these processes is the fact that unless employed through formal agencies, domestic servants or their families always have some connections with the recruiters or their employers. In addition, I observed three different patterns of relationships among recruiters, employers and domestic servants and their families. I refer to these as the non-familial relationship, the kin-group relationship and the shared-solidarity relationship. In the following paragraphs, I discuss these different patterns of relationships and how they impact the treatment of domestic servants by their employers and vice versa.

\section{Non-Familial Relationships}

The pattern of non-familial relationship exists where domestic servants work for total strangers who come from and live in different parts of the country. Such employers go through any of the three processes of recruitment to obtain their domestic servants. For the participants in this research, the informal process of recruitment tends to dominate, with appointments through family 
members being the most frequent. As would presently be outlined, a majority of the current domestic servants who participated in this research fell under this category. They could be recruited through any of the means outlined above.

The domestic servants that I knew while growing up lived in households where they had no kin ties. They were also not from the same hometowns with their employers. The dominance of children working for families that they were not related to is true for the participants in this study. The largest number of my respondents fell under this category of non-familiar relationship. As many as 25 of the 44 current domestic servants and nine of the 14 former domestic servants lived with people whom they were not in any way related to. Three of the 25 current domestic servants and 2 former domestic servants came from the same hometowns as their employers; the type of relationship existing between them and their employers will be outlined very shortly.

These 39 domestic servants either volunteered or accepted the offer to live in these strange households expecting that they would receive remuneration for their services. As already suggested, none of the domestic servants in this research lived with other households for altruistic reasons. The only person who could be exempted from this assertion is Selasie and Molly who were recruited between the tender ages of 2-3 years. Selasie, for instance, did not know why and how she came to live with her employer. All the others, including eight year old Hawa, knew that they were there either to be able to go to school or to be able to learn a trade after a specified period of service. 
Given the fact that they are not related to their employers, one would expect that employers would understand the children's reasons for accepting to provide the services and to keep their part of the deal. This was not the case with a majority of the domestic servants that I interviewed. If there was any understanding of the children's plight on the part of their employers, it was in regards to the desperateness of the children's struggle to live with other families in order to accumulate funds and other resources towards their skill training. That desperation, I assume, lead the employers to prolong the children's stay with them because of the anticipation that most of them would fear abrogating their contracts and forfeiting their accumulated incomes. Besides Lily, Selasie and Hawa and five of the older cohorts of former domestic servants who were very young at the time of their recruitment and so could not specify the number of years that they would like to stay in servitude, all the other domestic servants expected to be paid off at the end of their second year, unless they received regular payments at the end of every month. They, however, stayed longer than two years.

Although parents and or informal or non-formal recruiters often know where domestic servants live and can communicate with them and their employers, none of them ever intercedes to ensure that employers keep their promises. Often, parents did not have direct contacts with their domestic servant children but this was not the case for the recruiters. Derrick, Sophia, Ali and Ahmed stay in regular touch with their recruits. They told me that this was to make sure that the children were doing fine in servitude. Nevertheless, I did not 
observe any instance where they requested that employers enrolled their servants in training because the agreed period of two or three years had elapsed.

When living with unrelated families, domestic servants recruited through non-formal processes stand the risk of overstaying their contract period if they want to be enrolled into the chosen skill training, the surrogate parenthood of non-formal recruiters notwithstanding. In this research, there were six current domestic servants who were recruited through non-formal processes to live with strangers. One of them was Sophia's recruit who received a monthly wage as arranged. Mansah, one of Derrick's recruits whom I interviewed, got paid, but only when she decided to leave for wrongful accusation. Derrick told me he usually arranged with employers to keep the servants' pay until they were ready to leave, so Mansah receiving her pay at the time of her departure was not abnormal. Although he claims he ensures that his recruits are remunerated regularly, the other two servants that I encountered during this research never got paid at all. As Chapter Six will illustrate, Michael and his colleague domestic servant did not arrange to receive regular payments at the end of the month. Given the employer's sexual harassment of the girl, she ran away without getting paid. Michael also left because his employer suspected that he had connived with the girl in her escape. This employer was no longer cheerful towards him. As a result, this male servant also ran away, without pay.

Hawa was recruited to live with a stranger by his uncle. In interviews with this uncle and her employer, I learnt that she would be enrolled in an apprentice training when she came of age. At the time of this interview, she was only eight. 
She had already spent two years in servitude. I interviewed one of Ali's recruits. At the time, he was preparing to send her back because her parents had requested that she returned home. She did not receive any pay for her services. She did not indicate why she was not paid. My enquiries from Ahmed indicated that he would collect the pay and send it to her later.

Servants recruited through informal processes relative to those employed through non-formal processes are at a higher risk of exploitation. While it is not disputable that their parents know who to contact in case they wanted to stay in touch with their children in servitude, there was no sign of them ever contacting the employers about their children's pay. Consequently, informally recruited domestic servants who stay with strangers wait the longest to either leave servitude or to be enrolled into domestic servitude. Hawa's employer had another domestic servant, an older person, who was recruited at the age of eight. At the time of this interview, she had been living with her employer for eight years. This employer stated in the interview that this other servant had been employed through informal means, and that she was at the time, preparing to send her away. Despite her suggestion of paying her off in a very generous manner, I observe that the length of time that this girl had to stay in servitude probably makes that claim of generosity questionable.

Unlike those recruited by non-formal agents, domestic servants who are appointed through informal means usually lose their accumulated incomes if they decided to leave without agreeing on a departure date with their employers. Often they ran away. Below is a description by an employer of how she sent off 
a servant who decided to leave because the area was too quiet, individualistic

and thus lacked the type of mechanical cohesion she was used to in her village:

"...So the woman [an informal recruiter] rang me and told me that the girl is there. I should ... not to give her money to her because she, she the woman gave transport to bring her here, and the transport is I think 20,000 or so... So I should deduct that 20,000 from the payment. At that time I was paying her 30,000 , that is I think about three years ago. So I should deduct that money and then give the rest to her. So I took the woman's money, even the woman sent her maidservant to come and collect her money when they were coming. So I gave the rest to her, and she left ... So I collected all the things my daughter gave to her, I took it. I didn't give it to her. Even what she was wearing from top to slippers is mine. I took everything, because you haven't stayed here even for three months."

Employers' displeasure at the sudden departure of their servants, notwithstanding, some servants received partial compensation for their services. The servants receive such payments if their families consult with the employers about the payment. Doreen, 19, was living with her third employer at the time of this study. She told me that her current employers promised to let her start some type of skill training soon after her recruitment. I spoke to the female employer, and she told me otherwise. According to her, Doreen was going to be enrolled to become a hairdressing apprentice after two to three years. Nevertheless, Doreen was planning to leave at the end of two years if she had not started by then. She was forced to return to her parents when her first employer, a hairdresser who was training her at the time, decided to relocate in another town for personal reasons. The second family promised to help her continue with her training in hairdressing, but instead, made her sell bread and water in addition to household chores. 
Eight months into her stay with them, her employer's husband attempted to assault her sexually. Doreen had been raped before, and because of that experience, she decided to run away without informing anybody in her current employer's household. When her family returned to discuss her pay with the employing household, this family came up with a figure that was supposed to be paid her everyday, and from that, they made deductions for her breakfast, lunch and supper, and for medical expenses. As she said, the amount of money left was so meager she decided to never step a foot in that house again to say hello to them should she ever visit that neighborhood.

The on-going discussions in this section illustrate the manner in which the participants in this research are exploited. We observe their exploitation occurring through the length of time that they are required to stay before pay and through their remuneration. Although it is beneficial for some girls to live in servitude because they are able to learn a trade as a result, the extent of exploitation and humiliation that they go through might counteract these benefits. In the next subsection, we note that children who live with relatives suffer the same level of humiliation and exploitation.

\section{Kin Group Relationships}

The relationship existing between a domestic servant and her employer is categorized as kin group if they are related by blood or through marriage. The incidence of children living with older members in their extended families actually started this trend of domestic servitude in Ghana, according to the Director of 
Ghana's Department of Social Welfare, Mrs. Mary Amadu, one of the two government officials that $I$ interviewed in this research. Mrs. Amadu attributed domestic servitude in Ghana to the historical pattern of extended families allowing one of their younger female members to migrate with another member to a distant area in order to help her with domestic services. Reciprocally, the older family member was to provide the helper with free formal education and training in housekeeping. While this helped the domestic servant to acquire formal education and gender related skills, the family back home was spared the trouble of taking care of another member. Some of the older women whom I spoke to prior to this research and those who participated in the research confirmed the level of discrimination and exploitation that children living with extended family members had to endure while in servitude.

Out of 44 current domestic servants, seven lived with blood relations. There was one male among them. Five former domestic servants also lived with their own relatives. My pre-research expectation that domestic servants currently living with relatives would be least abused proved to be wrong for the respondents in this research. Complaints of abuses seemed to be more dominant among domestic servants who lived with their own relatives than the rest. Besides, they stayed much longer, on the average, than those who lived with non-relatives.

Like the other domestic servants, those who lived with blood relations complained of two things, verbal and or physical abuse and the lack of remuneration for their services. Their expectations of being enrolled in good 
private schools, S.S.S. or even be given the chance to learn trades as promised by their relative-employers were either never realized or took too long to come. In Michael's household, for instance, there was a third domestic servant who was related to their employer. I nicknamed him James. At the time of this research, James had lived with his cousin for eight years. He said his father sent him to this house so he could further his education at the S.S.S. level. He was there the first time, but there were about four servants. Hence, his cousin asked him to go away for sometime. A couple of months later, the cousin sent for him. He was elated at the invitation, thinking that he was going to be enrolled in school. For the next five years, he provided domestic services and took care of the lawn in the house. It was his cousin's new wife, who, soon after joining the household, sympathized with James' situation and consequently registered him as an apprentice in a tailor's shop. Faced with the difficulties of buying his own supplies for sewing practice as well as transportation to and from the tailoring shop, James decided to finally leave his cousin's house so he could sew on the side to make money. In a telephone conversation with him last year, he told me he had to leave his cousin's place because he had virtually stopped taking care of him financially.

Samira and Patricia also lived with some relatives. Patricia lived with her cousin at age 10. For close to 11 years, she provided domestic services but received nothing when her cousin asked her to leave. On her part, Samira lived with two relatives and when she had to leave, she received nothing from either employer. Although both of them went to school, the number of hours worked 
around the house or for engaging in economic activities prevented them from performing satisfactorily in school. At the time of this research, Samira was about to graduate from a vocational training school. She was learning to become a fashion designer.

Like Samira and Patricia, most of the domestic servants who lived with relatives in Accra did not have life and working conditions any better than those who lived with non-relatives. Their employers were primarily concerned about the gains that they made from these young women. Mary is another such victim. I found her at a shop at Teshie Nungua Estates. I explained the purpose of the research and requested her consent for me to interview her. She directed me to an older woman, probably in her mid-thirties, to ask for permission. Mary helped me with a stool and grabbed one for herself when the lady who is supposed to be her niece gave her the go-ahead to grant the interview. Throughout the interview, however, she wept from time to time. She kept turning and looking round. I could sense she was apprehensive about something, but had no idea that she had to go home for household chores around the time and was trying to avoid being seen by her cousin, her employer. About half-way through the interview, a car stopped in front of the shop. Without saying a word to me, Mary jumped out of her seat and rushed to the car. I thought she was going to help a customer and so paused the recording and waited. Soon, I saw her sit in the car and they went away.

I passed by the shop a couple of times to see if I could get Mary to complete the interview. Given the impression I got, I made sure I did not go in to 
ask of her for fear she could be penalized, although her employer's daughter gave me the initial permission to interview her. Mary's employer's background is thus unknown. Another respondent who shared Mary's type of servitude is Claudia. The difference between the two is that Mary completed the J.S.S. prior to her recruitment and lived with her relative at the time of the interview, while Claudia who lived with a non-relative lost her schooling to domestic servitude. Claudia kept a small convenience store in front of her employer's house and did very little domestic chores. Her employer was a full time petty trader.

As far as sexual harassment is concerned, only Doreen encountered it while living with her aunt. This occurred before she worked for non-relatives. The details of this assault are given under the subsection on why domestic servants prematurely leave servitude.

\section{Shared-Solidarity Relationships}

The shared-solidarity relationship exists when domestic servants and their employers come from the same village or hometown, but are not related by blood or through marriage. There were ten respondents who came from the same hometowns as the female heads (i.e. the wives of the male heads) of the households that they lived in. Only one former domestic servant came from the same hometown as a male employer. The female heads are always directly responsible for the domestic servants. With the exception of two cases, females usually arrange for servants to be recruited, gave them some type of informal 
orientation programs and supervised their work. This was true in all types of recruitment and relationship.

These interviews discovered how a family could maintain cordial and warm relationship with its domestic servants as a result of altruistic moral obligations, while others, in contrast, focus more on self-interested benefits from their servants and thus could not tolerate their poor services. I assumed that although the quest of cheap labor draws families to rely on informal means of recruitment and thus on the vulnerable positions of their hometown girls, the bond existing between the two groups for coming from the same village also plays a part in the relationship between these employers and their servants. I observed also that animosity usually existing between domestic servants and employers who come from same hometown as theirs are less intense than others, except in exceptional cases such as what existed between Emelia and her employer.

Two households at the University of Cape Coast lived with domestic servants who came from the wives' hometowns. The two female heads were married to university lecturers. Mrs. Biney, one of the two employers, showed the least differentiation between her own family and her domestic servants. I was able to interview her and two of her domestic servants, Rita and Cynthia. She usually allows her domestic servants to receive training to become hairdressers in her salon. Most of her domestic servants came from her hometown in the Western Region. As she pointed out, this connection served as the basis of her positive attitude towards her domestic servants. When she 
decided to no longer obtain young women from her hometown because of disrespectful behavior by some of them, she continued to exhibit similar commitment to the girls that she recruited from other villages. At the time of the interview, she lived with three girls one of whom was her sister's daughter, and another, a distant relative.

Serwah is another domestic servant who lived with a hometown person. Like Mrs. Biney's family, Serwah's employer had another domestic servant, but from a different village. Although Serwah was pleased with her status as a domestic servant in the city, her employer could not express similar sentiments about her. In an interview with this employer, I learnt that Serwah was not as smart and efficient as the other domestic servant who had lived in this household for over five years. This employer's dissatisfaction notwithstanding, she remained equally polite and generous to both of them. That is probably because of the hometown connection she shares with Serwah.

Unfortunately, the third respondent who lived with a hometown family, Emelia, did not enjoy the sort of cordial relationship that existed in Mrs. Biney's and Serwah's households. It was sad listening to some of her experiences in her current employer's household, although she appeared to be the strongest willed respondent in this research. At sixteen, she was living with her third employer. Both the second and third had come from the same hometown as hers. She willingly left the first employer when she was accused of having had a boyfriend. She, however, told me that she wished she could go back to that city to do the same chores - selling secondhand clothing - although not necessarily with the 
same employer. She received ill-treatment from her current employer as well as the latter's children, three in all. Usually, the employer was impatient whenever an argument ensued between the domestic servant and the children. The employer would not listen to this respondent's side of the story but jump to unfounded conclusions that usually resulted in the employer meting out some sort of punishment, at times mere insults, to the servant.

When I interviewed this employer, I noted that most of the allegations her domestic servant had made against her were correct. She was one of many employers who demonstrated in their responses to me that domestic servants have to be maltreated, or made to feel subservient to the rest of the family. For instance, she did not care when her children misbehaved towards her domestic servants. The choice of words that she used to describe her domestic servants to me was also demeaning. In all my visits to this family, I noted that both children and mother were not friendly towards the domestic servant.

This employer said she preferred girls from her village because of the passion and love she has for that community. In her opinion, these girls were mostly underprivileged and one way of helping to alleviate their plight was to bring them to the cities and give them at least a sewing machine when they leave. Usually, she promised to enroll them in skill training after a two-year stay with her. In case she decided to send them away for dissatisfactory services in which case the girls do not stay throughout the agreed period, her commitment to the girls from her village makes her see them off on a good note. She got them at least the sewing machine. Her second domestic servant lived with her for five 
years. It was in the fifth year that this girl started training in dressmaking.

Unfortunately, this employer suspected she had started dating and so sent her away. For her reward, this previous domestic servant received a sewing machine and some cash to pay part of her reenrollment into training.

Emelia lived with this employer for just about a year, and she was making preparations to send her back to the village. I realized that this employer had a high house-help turnover. There was the tendency for her and the rest of the family to be welcoming and tolerant the first few months of a helper's stay with them. Soon afterwards when the novelty wears off, petty mistakes on the part of the helper upset her. Consequently, she would either hit the helper or utter certain derogatory remarks that would cause the servants to feel uncomfortable, out of place and nostalgic. When asked what problems she had with the servants, Emelia's employer stated that

"One of them was a thief. She wasn't cheerful, she was always moody. The second one also stole a little bit. Some of them used to beat my children. They yelled at them. You buy your lactogen and they ate it, so you had to buy more than you needed so you will always have some for your children. This one specially has problem with boys. By the time you come back, she would have locked the door and left for her boyfriend. Send her to go for this [pointing to her son] from school, she will go with her boyfriend and ask him to stay outside and wait for her. When you leave, she makes so many phone calls, to a boy behind this building. If you ask her to do anything, she doesn't do it. She doesn't use her initiative and when you tell her, she doesn't do it."

To conclude, this section outlines the nature and type of relationships that exist between domestic servants and their employers. Domestic servants suffer abuses and exploitation in all three types of relationships. Nevertheless, girls 
who lived with their relatives gave the impressions of being the worst exploited and abused in this study. They had to stay longer than normal before any training, and if they left on a bad note, they were denied any payment due them.

Girls who came from same hometowns as their employers stood a higher chance of a satisfactory relationship with their employing households. I assumed that such employers felt it a moral obligation to be honest to their hometown girls, although the domestic servants in such relationships were not always allowed to learn a trade within the agreed period.

\section{CHAPTER SUMMARY AND CONCLUSION}

This dissertation discovers three processes of recruitment, namely formal, non-formal and informal processes respectively. The interviews show that domestic servants who are recruited through the formal processes are usually older than the minimum working age and they usually complete the basic education before accepting such offers. Some of the servants recruited through non-formal processes complete the basic education, but are usually younger than 18 years. Unless their recruiters and families arrange with their employers to pay them regularly, they may have to wait until the end of the agreed period of service to get paid. In that case, if the servant decided to leave before that period, she may lose the accumulated income. Unlike these two categories of domestic servants, those recruited through informal processes usually lived with relatives or non-relatives that their families have some contacts with. These are 
more likely to be exploited and to stay longer before receiving payment for their service.

The processes of recruitment that this dissertation observes among the participants are not enslaving. In all three forms of recruitment, I observed that children exercise the right of participating in the decisions about their enrollment into domestic servitude although they believe that their parents should have the last say. Contrary to what exists in other societies, the domestic servants who responded to this research were relatively mature and knowledgeable enough to understand the demands of their responsibilities. They understand the financial constraints facing their parents and the fact that child domestic servitude is probably the only avenue through which they would receive the training that they expect.

The only exceptions were those current and former domestic servants who were recruited between 3 and 12 years and so did not understand the purpose and implications of their servitude, or simply because they are below the minimum working age, that is if we consider the age of 13 permitted for children to work in light industry. Such servants were more likely to have dropped out of school or were never enrolled at all. If they stayed longer without contact with their biological families, they may not be able to trace their way back home should it become necessary for them to leave. 


\section{CHAPTER FIVE}

\section{CULTURE OF GHANA AND ITS IMPACT ON CHILD DOMESTIC SERVITUDE}

The literature suggests that three interrelated factors define and determine the chances of women in Africa and Ghana in particular. These are indigenous gender structures, lack of women's access to credit and capital, and economic growth and development policies. In previous sections, I discussed existing reports on development programs and how they negatively affected the lives of Ghanaians in general. Other research focused on the impact of neo-liberal economic policies which, while interacting with existing traditional gender structures and norms, neglected women's economic roles and thus intensified their lack of access to vital socioeconomic resources. These gender and economic structures subordinating women's statuses in some Ghanaian cultures to those of men also make it easy for girls to be exploited within the household as domestic servants.

Although these structures do not directly prevent girls from accessing formal education, their willingness to accept offers of domestic servitude partially depends on them. My research discovered, for instance, that girls accept to work as domestic servants because they expect to learn gender related roles. Also, employers and recruiters showed in this study that the latter prefer to hire girls as servants because of the gender-related chores they assign them. As Chapter Six will additionally point out, girls end up in domestic servitude also because of 
their parents' inability to finance their high school education. In this chapter, I discuss the literature on gender constructions inherent in patterns of lineage in Ghana and outline their relationship to child domestic servitude as are observable in my research.

Gender is "the constellation of rules and identities that prescribe behavior for persons, in their social roles as men and women" (Kevane, 2004: 1). Every society has its characteristic gender traits (Kevane, 2004). Some core values of these traits survive external pressures and remain relatively stable over a significant period. Core values governing inheritance and succession in Ghana, for example, have seen very little change. These values demonstrate unequal power distribution among males and females, however, some scholars including Onyeke Oyewumi (1997), Ifi Amadiume (1987) and Sean Hawkins (2002) attribute certain aspects of African gender structures to processes of colonization. Although arguments invalidating this assertion are beyond the scope of this dissertation, we observe that elements of pre-colonial gender structures that have outlived socio-cultural changes in Ghana also impact socialization of children and the induction of girls into domestic servitude.

\section{LINEAGE AND GENDER STRUCTURES IN GHANA}

While it is not disputable that there is a misrepresentation of African women in some Western gender and feminist discourse as the scholars mentioned above argue, patterns of descent in those African countries where 
these scholars researched exhibit pre-colonial discriminatory gender structures that were tilted against women, and which interacted with emergent colonial structures to create the category of disadvantaged women that we witness today in African cultures. As Jeanne Henn (1984) suggests, matriliny did not alter the fundamental principles of the patriarchal order, which I presume existed before colonization. Women's power and statuses were subordinated to those of men. Gender structures in African countries derive from traditional systems of descent, which define rights of inheritance and succession. These patterns are usually matrilineal or patrilineal. In matrilineal societies, all males and females trace their descent through a female line, from a common ancestry (Nukunya, 1992; Stoeltje, 1995). Jeanne K. Henn (1984) defines it as "the practice of tracing kinship allegiance and inheritance rights through the mother's family" (Henn, 1984: 8). In this system, a woman's brother with whom she shares the same mother is responsible for her children. Both males and females whose biological fathers belong to a particular matrilineal group cannot inherit or succeed anybody within that group. Usually, the lineage has a head (the Abusua Panin). This head has to belong to the family matrilineally, and must always be a male (Nukunya, 1992). The only exception Mpohor Wassa District of the Western Region where two women have been made chiefs, rather than queenmothers as is the norm in other traditional areas. In Ghana, the Akan speaking peoples of Ashanti, Akim, Akwapim, Brong, Fante and Ahanta ethnic groups are matrilineal (Nukunya, 1992). An estimated $49 \%$ of the research 
population is matrilineal (Ghana Home Page, 2005), although in the rest of Africa, patrilineal systems outnumber matriliny by far (Nukunya, 1992).

Political power in matrilineal families is usually the antithesis of what exists within patrilineages. Women in patrilineal societies are relatively less powerful than their counterparts in matrilineal groups. In this system, males and females trace their lineage through a male line to a common ancestor. Unlike matrilineal relationships, fathers are responsible for their own children (Nukunya, 1992). In their absence, their children become the responsibility of their paternal brothers who are considered traditionally eligible for inheritance. In Ghana, the Ewe, the Ga, the Adangme, the Kusasi, the Gonja, Dagomba, Kokomba and Mamprusi ethnic groups are patrilineal. The Yoruba of Nigeria, which Oyewumi researched, are also patrilineal.

While conventional knowledge has it that matrilineal systems vest more power in females than males, rules of inheritance, widowhood rituals and traditional political systems empower males in both matrilineal and patrilineal systems, thus making females the subservient category in either system. The rules of inheritance and succession are intertwined with those of widowhood and its rituals, rites of marriage and traditional political systems to render women generally less powerful.

The matrilineal woman's acclaimed power, although true relative to their counterparts in patriliny, stems from and probably rests with their biological relationship to their children. Given that persons who are eligible for succession and inheritance in matrilineal systems must trace their ancestry, biologically, 
through their mothers, the woman's role in the family's certainty of their blood relatives is, inarguably, an immense one. The importance of the matrilineal mother's role is indispensable especially in the absence of advanced scientific methods such as DNA testing to certify maternity or paternity. In fact oral history has it that Akan royal households preferred matriliny because of the higher probability of being certain of the mother's biological relationship to her child, which is not the same for that existing between fathers and their offspring. Akan groups believe that the woman's biological link to her children is fully guaranteed, while the father's blood relationship with his children could be questioned. In view of this, the chiefs, kings, queen-mothers and all people occupying prominent traditional positions have always been selected based on their maternal relationship to the family.

Matrilineal women enjoy another important role of power, albeit one restricted to those from royal households and who end up as queen-mothers. The queen-mother is privileged to be the only person who could select the king or the chief. This power is, however, limited by the whims of an all male kingmaking sub-committee who could place impediments in her way, by finding faults with and rejecting the person she chooses. Beyond the queen-mother's privilege of selecting the prospective chief or king for vetting by the more superior kingmaking sub-committee, she has no power over the chief. She is as much a subject of the chief's as any other member of the community. This shows that even in matrilineal groups, the woman's political power is subordinated to that of males. That state of subordination is manifested in taboos that prevent the 
queen-mother and all other women from entering some palace shrines, and from entering the palace when they see their periods.

Processes of traditional marriage also vest more power in men than in women. This is observed in the important roles that maternal uncles, rather than mothers, play in the marriage rites of their maternal sisters' children. Uncles usually oversee marriages of these nieces to serve as liaison between his family (and that of the bride to be) and the groom and his family. The Akan traditional marriage, for instance, entails different stages, and at each stage the husbandto-be presents gifts to the bride's family and her father (Nukunya, 1992; Tashjion \& Allman, 2002), usually through the bride's uncles. The mother through whom the bride is a legitimate member of the lineage is only assigned roles that are relatively less important and requiring no leadership skills. She and other female elders of the kinship group counsel the bride about feminine and passive female roles in marriages.

Matriliny and patriliny also define separate patterns of residence for married couples, although married couples utilize both maternal and paternal ties in their household organizations and patterns of residence (Nukunya, 1992). Historically, patrilineal societies have had more specified residential patterns. They were usually patrilocal. Under this system, married couples had to live in the husband's father's home (Nukunya, 1992). The pattern of residence could also be duolocal, in which case the couple lived in separate homes. This existed among the Ga people of Accra, Ghana. Residential patterns are not so distinct among matrilineal groups. Some of them are patrilocal and since this contradicts 
matrilineal values, children belonging to such couples may have to live with their mother's family (Nukunya, 1992).

Women who marry into patrilineal families are considered strangers (Nukunya, 1992) and for that matter, are less powerful relative to the men in these groups. Husbands exercise the right of using their wives' labor (Nukunya, 1992; Hawkins, 2002) and thus derive invaluable productive and reproductive benefits from them. Women in pre-colonial patrilineal systems served as a source of labor for their husbands (Henn, 1984; Coquery-Vidrovitch, 1997). As Godwin K. Nukunya (1992) suggests, “... in a patrilineal society, a married woman bears children for her husband's lineage" (Nukunya, 1992: 43).

In most of pre-colonial Africa, labor, rather than land, was scarcest of all the factors of production. Hence, husbands from either matrilineal or patrilineal ethnic groups relied on their wives' labor and those of their children for work on their fields (Henn, 1984: 5). It is against this background that some scholars attribute the emergence of polygyny to women's productive role on their husband's field and their reproductive role, which ensure that there is a pool of free labor supply for males (Coquery-Vidrovitch, 1997; Henn, 1984). As Catherine Cockquery (1997) puts it, "for the family receiving, whether birth family or future in laws, a girl was a source of wealth - a promise of work and a guarantee of children" (10).

Besides farm labor, women had to provide domestic services that included fetching water from the stream, cooking, cleaning and looking after the children (Tashjian and Allman, 2002). In exchange for her services, the husband 
provided care and maintenance for their wives. They provided meat, clothing and food (Tashjion and Allman, 2002).

Today, the husband's advantaged position over their spouses is slowly dwindling because of

...comparative resources which husband and wife bring to marriage, such as education and income and the type of occupational and kinship positions each maintains outside the conjugal family, as well as by the prescribed and traditional authority patterns of the cultures to which they belong (Oppong, 1974: 115).

Christine Oppong (1974) states further that "wherever women have access to strategic resources, being important economic producers and managers of property, their part in domestic decision-making has been shown in numerous studies to be potentially enhanced "(Oppong, 1974: 115). Unfortunately, women's lack of access to information, capital, private savings and their underprivileged statuses in terms of educational opportunities and attainment as outlined earlier make the dwindling in male powers slower if not impossible for many poor women in both rural and urban regions.

Most of the need for female labor on farms existed in rural regions. Nevertheless, these persistent gender structures determined the kind of work that they did in pre-colonial and colonial cities (Guyer, 1984: 35). As suggested earlier, these structures continue to thwart women's development in many low income countries. "Only a few women have been able to overcome the socioeconomic constraints that keep women illiterate, poorly paid, or marginally self-employed" (Guyer, 1984: 35). The only contribution that colonization made 
to that, which in itself was enormous, is the monetization of African economies. Some farm produce were converted into cash crops and men dominated their cultivation. If what Oyewumi, Amadiume and the others suggest is correct, then it is in terms of gender-related changes that occurred through the monetization of African economies. Men had more access to wage labor and to the production of cash crops. The impact of such privileges has continued until today in some cultures.

The bulk of the changes resulting from colonization occurred through monetization of the economies in Africa. Colonization introduced cash crops such as cocoa and coffee to many Sub-Saharan African countries. Although women and men cultivated some crops for household consumption prior to that period, this changed with the onset of cash cropping. Land needed for food crop cultivation was switched for cash cropping. Men became responsible for the cash crops, while women concentrated on food crops (Coquery-Vidrovitch, 1997; Guyer, 1984). Among the Brongs of Ghana, for instance, both men and women cultivated cotton and indigo for household consumption until these became cash crops and consequently the specialization of men (Stahl and Cruz, 1998). In Ashanti Region also, lands originally used for food crops were diverted for cocoa production and thus the specialization of men. Women became the economic and social dependents of men while they remained responsible for the cultivation of food crops for their household's consumption (Henn, 1984).

When fertile lands for cash and food cropping were exhausted, Ashanti men migrated to the Brong Ahafo and Western Regions to further their cash crop 
production. Urbanization occurred around the same time, causing rural men to migrate to urban centers in search of wage labor. In order to force African males to desert their farms to work in European enterprises in the cities, property taxes were introduced in some African colonies by 1903 (White, 1984). Given that lands in some farming areas had become less fertile and also that these property taxes were not affordable by rural residents, males had to succumb to work in European enterprises in the cities. These created vacuums within households, thus increasing the workload on women. Although women could be economically independent (Henn, 1984), colonial measures and missionary policies prevented them from migrating into the big cities, unlike men (Obbo, 1980; CoqueryVidrovtch, 1997), in pursuit of paid occupations. Most women became household heads, as a result.

This burden has persisted until today. The [rural] African woman's "labor day has seen very little change", as Henn suggests (Henn, 1984:1). Most days, they must work in the fields from four to eight hours, aided only by a simple hoe, in order to provide their families' basic food (Boserup, 1970; Henn, 1984; Guyer, 1984). They must also work a second labor day fetching firewood and water, and drying, shelling, and storing and cooking the foods from their gardens, all the while caring for their children (Henn, 1984: 2). Therefore, they could not make the time to listen to agronomists or to receive the training that would enhance productive roles within the household. They could not go to school either. As a result, they could not get wage labor (Guyer, 1984) and besides work on farms, became self-employed. Women's authority in market trading was carried over 
into the post-colonial era, but the same constraints mentioned earlier have prevented a large number of them from expanding their businesses (Guyer, 1984).

\section{RELATIONSHIP BETWEEN GENDER ROLE EXPECTATIONS AND CHILD DOMESTIC SERVITUDE}

These historical attributes of gender relations and lineage in Ghana, to some extent, have connections to the employment of children in domestic servitude today. Although the lack of educational resources in rural regions negatively affect both boys and girls, the concentration of girls in domestic servitude reflect the tradition of girls being confined to the private sphere, and women's poor conditions in rural regions. Mothers and, in some cases fathers, among the respondents in this research look for opportunities of better standards of living for their children. Both parents and children prefer that the latter avoid the problem of living in the rural area and working long hours in the fields and around the house. As I will soon illustrate, both parents and children believe that living in the cities will not only help female children escape long hours of farming and walking long distances to fetch water and firewood in addition to other household chores, but be able to learn roles that will make them good mothers and wives. This subsection discusses the role of gender socialization, patterns of inheritance and succession and other cultural practices in the incidence of child domestic servitude in Ghana. 
That young women and girls would be able to learn gender related roles, the Director of Ghana's Social Welfare, Mrs. Mary Amadu pointed out, was the primary reason for families to allow their younger members to live with older relatives in the past. As mentioned earlier, she suggested that previously, families allowed their younger members to migrate with newly married relations in order to assist them with domestic chores. In return, the older relative put the younger girl through formal education, provided them with informal training in general etiquette, housekeeping skills and the chance to learn a trade.

What the Director of Social Welfare told me corroborated my pre-research discussion with women who lived as domestic servants in the 1950s through the 1960s. I learnt that they lived mostly with relatives. The older cohorts of domestic servants, with the exception of Esther, lived with members of their extended families because that was the practice then, just to paraphrase what some of my respondents stated.

Responses by parents, employers and domestic servants reflect the influence of gender constructions on contemporary child domestic servitude. They point to an interaction between gender role expectations, lack of funding and educational resources to create domestic servitude among girls. If this were not the case, both boys and girls will be tracked into same activities when they are not able to enter senior secondary schools or to continue their education at the relevant levels.

Domestic servants asserted in the interviews that parents prefer their daughters to enter domestic servitude instead of their sons because of the nature 
of the responsibilities of domestics. A large number of them believe that they can learn good manners, as are defined by their cultures, while living in the cities. I felt this had nothing to do with the respondents' own wellbeing, but that of their future husbands. At very young ages, they had already been socialized into being successful objects for their future husbands. They agreed that living in the cities would enhance their effectiveness in their objective positions as wives. As Akosua put it,

"When you live with your parents, you are spoilt. When they send you, you can choose not to go. When you live with other families... when you live with your mother and you work hard, you never find yourself wanting whenever you go to live somewhere else. If you work hard when living with other families, you will never find yourself wanting wherever you go. Besides, when you live with your mother, you won't live with her forever. A day will come when you will be married and be living in your husband's home. There, it won't be your mother who will be cooking for you then."

Serwah who was 15 years at the time of my field research put it this way,

"Some parents want their children to have some exposure. Some want their children to stay away from boys. There are those also who want their children to learn how to serve their husbands. They live in the villages and don't know what is going on. When they come here, they know what is going on, like being respectful, not calling people names."

Employers gave the same explanations for preferring girls, and added that to some extent, they were scared of the possibility of boys robbing them of their belongings or sexually abusing their young daughters. Only one employer confirmed knowing a household whose belongings were once stolen by a houseboy. Where households hired boys, this was usually in addition to domestic servants and such boys were responsible for male related gender roles 
like gardening, the care of livestock if any, washing vehicles and doing the laundry for the male household heads. As mentioned in previous chapters, there were two male respondents in this research, and they were primarily responsible for these male roles.

Methods of payment of domestic servitude among older cohorts of domestic servants also point to the role of gender in the continued existence of this phenomenon in Ghana. Employers of domestic servants in the era before the 1980 s usually performed initiation ceremonies in the form of puberty rites for their servants. At puberty, Ghanaian boys did not have to go through any special rituals. The girls, however, were subjected to yet another culture-specific socialization - the puberty rites, which are not organized as much as they used to in the period preceding the 1970s.

Puberty rites are special traditional ceremonies that were organized for girls to initiate them into adulthood and to honor them for not getting pregnant before their marriage. Historically, girls who became pregnant without having gone through this initiation ceremony and being duly married were banished from their communities. These traditions became relaxed in the 1970 s and today, it is hardly observed in most societies. Such initiation ceremonies differed from culture to culture among the research population.

Puberty rites for girls in the Ashanti Region began at dawn with a pouring of libation and preparation by the parents and members of the extended family to formally outdoor the girl in question. Throughout the day, the girl is adorned in expensive traditional clothing and seated on a traditional stool in an open yard to 
receive gifts and to listen to words of wisdom from well-wishers. At dusk, she will be escorted to her room to begin a week of confinement. Throughout that period, the girl would receive training on motherhood, marriage, and about expectations of transitioning from childhood into adulthood. Today, no town or village in the Ashanti Region performs this ritual for its girls, probably as a result of cultural diffusion, social change and the influence of formal education on the status of the average Ghanaian woman. It is highly unlikely for educated women to consider this tradition relevant to their socio-cultural and economic development.

Given the cultural relevance attached to puberty rites for girls among the Ashantis, I believe families of domestic servants found it sufficient for their girls to be provided the chance of going through this ceremony in lieu of cash payment for their services. Like the women I talked to before this research, the domestic servants of the pre-1980 era did not usually enter into agreements with their employers with regards to the method of payment, length of time required of them to serve, and how much they would be paid. They lived in servitude for as long as it took for them to get married. Before that though, the relatives they lived with organized the puberty rites for them. As part of the puberty rites, their employers presented them with kitchen utensils, traditional cloths and other personal effects, which are symbolic of female gender constructions.

Although these findings substantiate observations in the literature about the domination of girls in domestic servitude around the world, the data did not point to gender related assertions in the literature that parents allowed their daughters into domestic servitude because of the belief that they would be 
secure there. Parents were more concerned about their daughters' economic placement and their marriageability in adulthood.

\section{INFLUENCE OF LINEAGE ON CHILD DOMESTIC SERVITUDE: STATISTICAL CONTEXT}

Patterns of lineage further influence domestic servitude and child labor in general in other ways. Using findings from the quantitative data, I discuss the relationship between lineage and child labor in the following paragraphs. Prior to that, this subsection discusses patterns of relationships observed between lineage and domestic servitude in the qualitative data.

There were more domestic servants from matrilineal than patrilineal backgrounds in the qualitative research. Out of the 44 current domestic servants who participated in this research, 33 came from matrilineal ethnic backgrounds, while the other 11 respondents were patrilineal. Only one former domestic servant was patrilineal. I was not able to interview many former domestic servants from patrilineal backgrounds because I did not visit predominantly patrilineal societies.

I observed that unlike children from matrilineal groups, those from patriliny are more independent of their families whilst they live in servitude, and employers prefer them, especially those from the Northern, Upper East and Upper West Regions to all other domestic servants. I learnt from some employers that they were more humble and hardworking. In this research, all 
those children who could not trace their parents' houses were members of patrilineal ethnic groups. Furthermore, they live with total strangers, unlike children from matrilineal backgrounds.

Given their independence of their families while in servitude, I noticed from the qualitative data that domestic servants from patrilineal ethnic groups usually stay longer than those from matrilineal backgrounds. Some of them refuse to return home when they leave any particular households. Rather, they independently look for other households to live with. One employer, for instance told me that she met her previous domestic servant, a northerner, at the market where the latter worked as a porter. It was this porter who asked my respondent to employer her as a domestic servant.

From the poverty map on page 53 , we observe that the incidence of poverty in patrilineal ethnic groups is higher than it occurs among matrilineal groups. Therefore, domestic servants from such communities probably stay longer because of the fear of living in severe poverty should they return to their villages without having become economically independent. It also explains their independence of their families. The current domestic servant of the employer that I just spoke told me that she and a friend of hers decided to leave school one day and to run away to the south to look for jobs as porters or domestic servants. They were about 13 years at the time.

These observations made immense contributions to the statistical analyses of the relationship between lineage and child domestic servitude. Based on the above conclusions, I hypothesized that a relationship existed 
between lineage and child labor in Ghana and conducted various statistical tests to answer the research question what is the role of lineage in the incidence of child labor exploitation in Ghana? The independent variable in this question is lineage, while child domestic labor is the dependent variable.

Table VIl: Distribution of Ethnic Groups

\begin{tabular}{lcc} 
& & \\
Akan & Frequency & Percentage \\
Ga- Adangbe & 7,387 & 44.3 \\
Ewe & 1,240 & 7.4 \\
Guan & 1,953 & 11.7 \\
Gurma & 621 & 3.7 \\
Mole-Dagbani & 1,200 & 7.2 \\
Grussi & 3,111 & 18.7 \\
Mande & 590 & 3.5 \\
Other & 318 & 1.9 \\
Total & 237 & 1.4 \\
\hline
\end{tabular}

Table VIII: Distribution of Lineage

$\begin{array}{lcc} & \text { Frequency } & \text { Percentage } \\ \text { Matrilineal } & 7,387 & 45.0 \\ \text { Patrilineal } & 9,033 & 55.0 \\ \text { Total } & 16,420 & 100.0\end{array}$


Table VII provides the frequency distribution of ethnic groups among the participants in the survey. The variable of lineage was derived from these ethnic groups, bearing in mind that of all the groups covered in the survey and in fact in the whole of Ghana, only Akans are matrilineal. The survey covers more ethnic groups than did the interviews. The qualitative research contained responses from Ewes, Akans, Gas and Kusasi. When ethnicity is transformed into lineage with the two response variables of "patriliny" and "matriliny" while the "other" category is excluded in addition to all missing cases, the outcome is presented in Table VIII. I treated the "other" category as missing because of the fact that in reality there is no additional category of lineage among the research population. Table III shows that $45 \%$ of the sample is matrilineal, while the other $55 \%$ is patrilineal.

Both the dependent (child labor) and the independent (lineage) variables of the research question above were categorical, hence the following numerous chi-square tests were conducted to determine if bivariate associations exist between the independent variable and the dependent variables, the level of strength of the association between them, if any, and the pattern or direction of that association. Child labor is operationalized as "child workers" or "child servants" using the new variables created earlier. However, given the broad nature of "child labor" as a dependent variable, other variables were selected to make the tests focused. These dependent variables were relationship with the head of household (whether good or bad), educational attainment, reasons for 
working, and expectations of what would happen if respondents stopped working, respondents' future goals and their relationship to their household heads.

Hypothesis Test 1: Relationship between Lineage and the incidence of Child Domestic Servitude

$$
\begin{aligned}
& H_{0}=\text { no association exists between lineage and child servants; } \\
& H_{1}=\text { an association exists between lineage and child servants. }
\end{aligned}
$$

The hypothesis above was tested through a two-way contingency table analysis. The main goal was to determine if lineage influences the decision about whom domestic servants lived with - relatives or non-relatives. The variables were lineage with two nominal levels, namely patriliny and matriliny; and child servants, also with two nominal levels, namely other relatives and non relatives of respondents' household heads. Table IX provides the results of these analyses.

Table IX: Relationship between Incidence of Child Domestic Servitude and

\begin{tabular}{|c|c|c|c|c|c|c|}
\hline \multirow[b]{2}{*}{ Status of Enrollment } & \multicolumn{2}{|c|}{ Matrilineal } & \multicolumn{2}{|c|}{ Patrilineal } & \multicolumn{2}{|c|}{ Total } \\
\hline & No. & $\%$ & No. & $\%$ & No. & $\%$ \\
\hline Other Relatives & 580 & 81.7 & 631 & 85.9 & 1,211 & 83.8 \\
\hline Non-relatives & 130 & 18.3 & 104 & 14.1 & 234 & 16.4 \\
\hline Total & 710 & 100.0 & 735 & 100.0 & 1,445 & 100.0 \\
\hline \multicolumn{2}{|c|}{ Pearson Chi-Square $\left(X^{2}\right)=4.6$} & $D F=1$ & \multicolumn{4}{|c|}{ Sig. $P=.032$} \\
\hline
\end{tabular}
Lineage 
Nearly $82 \%$ of respondents coming from matrilineal backgrounds live with other relatives, while a little over $18 \%$ of them live with non-relatives. Among patrilineal groups also, approximately $86 \%$ live with relatives while close to $14 \%$ live with non-relatives. In that table, we observe this relationship to be statistically significant at $\alpha=.05$ [Pearson $X^{2}=(1, N=1,445)=4.61$, sig. $=.032$ ] The null hypothesis of no association between lineage and child servants was thus rejected. The phi $(\varnothing=-.056)$ indicates, however, that this association is only moderate, confirming the earlier observation made in the qualitative analyses. While this test shows that a moderate relationship exists between lineage and child domestic servitude, it is observed that children from both patrilineal and matrilineal households are more likely to live with other relatives than nonrelatives. This similarity notwithstanding, it is observed that children from patrilineal ethnic groups are more likely to live with relatives than non-relatives; and children from matrilineal ethnic groups are more likely to live with nonrelatives.

As pointed out earlier, the qualitative analyses corroborate existing findings that poverty is the primary cause of child labor exploitation. Among participants in the qualitative part of this research, escaping rural poverty either before or after completing or dropping out of elementary school dominates the reasons for children's acceptance of employment into domestic servitude. In Hypothesis Test 2, this research aimed at finding out if a statistical association exists between lineage and child domestic servitude. 


\section{Hypothesis Test 2: Association between Lineage and Reasons for Children's Work}

$H_{0}=$ no association exists between lineage and reasons why children work;

$H_{1}=$ an association exists between lineage and reasons why children work.

Table X presents the findings from a two-way contingency test conducted to determine if any statistical association exists between these two variables. Unlike Hypothesis Test 1, which included only children living with other relatives and non-relatives, Hypothesis Test 2 included all children, namely, those who live with their parents, sons/daughters-in-law, grandchildren and brothers and sisters who were aged below 18 years. Sons- and daughters-in-law were included in this test primarily because of their age; and secondarily because they are not heads of their households or the spouses of the household head. Their age and relationship to the household head, it was presumed, make them dependents of their fathers- and or mothers-in-law who headed their households.

Given a Pearson $X^{2}(7, N=6,204)=136$, sig. $=.000$ and $\alpha=.05$, the data again confirm the relationship between lineage and child labor. Consequently, the $H_{0}$ of no association between lineage and reasons why people work is rejected. A Cramer's V score of .15 , nevertheless, is an indication that this relationship is not a strong one.

From the table, we observe that less than $.5 \%$ of patrilineal and matrilineal children respectively work, in Ghana, to settle their family's outstanding debts. A majority of them (nearly $51 \%$ of matrilineal children and $64.2 \%$ of patrilineal 
children) work in order to supplement their household incomes. Closely related to the quest of supplementing household income is children's need to work to support household enterprises. As much as $41 \%$ of matrilineal and $29 \%$ of patrilineal children work to help household enterprises. Although the inability to afford school fees should be related to the need for children to work to support their family business or to supplement household incomes, only $2 \%$ of matrilineal and $2.3 \%$ of patrilineal children work because they cannot afford school fees. These small proportions of those who work because of inability to pay tuition corroborates the observation in the interviews that a large number of the participants had been able to complete the basic education but needed support for further training or schooling. This could also mean that the Free Compulsory Universal Basic Education (FCUBE), which will be discussed in details in the chapter on education, has been successful at ensuring that children went to school without any financial costs to their parents or guardians.

Given the main focus of this dissertation on children who usually leave their own families to work for other households as resident servants, the above test was reconducted, but relationship to the head of household was recoded and controlled for. As stated earlier, relationship to head of households was recoded first to include the heads' children and grandchildren but excluding siblings, inlaws and spouses. When we control for relationship to the head of household, we observe a slight change in the proportions of children who work to either support their family incomes or to help family enterprises. 
Table X: Bivariate Association between Reasons why Children Work and Lineage

\begin{tabular}{|c|c|c|c|c|c|c|}
\hline \multirow[b]{2}{*}{ Reasons for Working } & \multicolumn{2}{|c|}{ Matrilineal } & \multicolumn{2}{|c|}{ Patrilineal } & \multicolumn{2}{|c|}{ Total } \\
\hline & No. & $\%$ & No. & $\%$ & No. & $\%$ \\
\hline $\begin{array}{l}\text { To supplement } \\
\text { Household Income }\end{array}$ & 1,145 & 50.8 & 2,537 & 64.2 & 3,682 & 59.3 \\
\hline $\begin{array}{l}\text { To pay outstanding } \\
\text { Household Debt }\end{array}$ & 2 & .1 & 4 & .1 & 6 & .1 \\
\hline $\begin{array}{l}\text { To help in } \\
\text { Household enterprise }\end{array}$ & 933 & 41.4 & 1,162 & 29.4 & 2,090 & 33.8 \\
\hline $\begin{array}{l}\text { Education or training } \\
\text { Program not useful }\end{array}$ & 3 & .1 & 9 & .2 & 12 & .2 \\
\hline $\begin{array}{l}\text { Education or training } \\
\text { Institution too far }\end{array}$ & 2 & .1 & 24 & .6 & 26 & .4 \\
\hline $\begin{array}{l}\text { Cannot Afford School } \\
\text { Or training fees }\end{array}$ & 44 & 2.0 & 90 & 2.3 & 134 & 2.2 \\
\hline $\begin{array}{l}\text { Child not interested } \\
\text { In school }\end{array}$ & 53 & 2.4 & 50 & 1.3 & 103 & 1.7 \\
\hline Other & 72 & 3.2 & 74 & 1.9 & 146 & 2.4 \\
\hline Total & 2,254 & 100.0 & 3,950 & 100.0 & 6,204 & 100.0 \\
\hline $\begin{array}{l}\text { Pearson Chi-Square }( \\
\text { Cramer's } V=.148\end{array}$ & $=136$ & $\mathrm{DF}=7$ & Sig & $. P=.000$ & & \\
\hline
\end{tabular}

Nearly $51 \%$ of matrilineal and $64 \%$ of patrilineal children who live with "other relatives" work to support their households' income. Among those who live with non-relatives, $36 \%$ of matrilineal and $48 \%$ of patrilineal children work to supplement household incomes. The data also shows that about $30 \%$ of matrilineal and $29.7 \%$ of children who live with other relatives work to support 
family enterprises. Furthermore, nearly $29 \%$ of matrilineal and $40 \%$ of patrilineal children who live with "other relatives" work to support family enterprises.

When we include the control variable of "child servants" the data does not provide enough evidence against the $H_{0}$ of no association between lineage and children who live with other relatives, given a Pearson $X^{2}(5, N=434)=5.45$ and a Cramer's $V$ score of .363 . We therefore fail to reject the null hypothesis in relation to child servants who live with other family members. For children who live with non-relatives, however, a statistically significant relationship exists between lineage and child servants, given Pearson $X^{2}(4, N=128)=10.54$ and $\alpha$ $=.05$. A Cramer's $V$ of .032 indicates though that this relationship is only moderate.

\section{OTHER TRADITIONAL PRACTICES AND CHILD DOMESTIC SERVITUDE}

Besides gender and lineage, other cultural practices such as traditional beliefs about infant mortality also played a role in the incidence of domestic servitude, although this was particularly characteristic of the older cohorts of former domestic servants. The reasons for the enrollment of the domestic servants who lived around the 1960s were more cultural than economic. This subsection discusses these other cultural reasons that allow children to live with other families.

Yvonne is one of the older cohorts of the former domestic servants. I met her at Nankasido, a village near Saltpond where I interviewed Lydia's - a current 
domestic servant - relative and recruiter. Yvonne was sent to live with her father's aunt when she was "very, very young, I had just started walking when they came for me" she said. She could not explain the purpose of her stay with her father's relation because "in those days, mothers allowed their children to live with their fathers' relations. Therefore we the children cannot explain why our mothers sent us away..." Yvonne started school while living with her father's relative but dropped out when she went back to her parents. Her mother came for her when her aunt beat her for losing an earring. At her mother's place, she went back to school but dropped out because she was a "spoilt kid," she concluded. She could do whatever she liked because her parents did not want to upset her.

Religious beliefs also characterized the older generation's stay with other families, hence the cultural influence on domestic servitude in those days. Oral history has it that where a woman experienced a high rate of childbirth, it was believed that the same child kept reincarnating. Part of the belief was that such a child had another mother in the spirit world, a mother who needed to be pacified in order to guarantee the earthly survival of the child. Yvonne and another respondent from the same village and same era of domestic servitude, Tanya, survived constant child mortality that their mothers experienced. Therefore, although they did not categorically indicate that their parents decided to give them away in order to subvert their risk of early mortality, I suspected this was a possible reason. They both indicated that in those days, children had to live with their father's sisters, that is why they were sent away at early ages. They could 
not, however, explain why children had to live with their paternal aunts although that negated the Akan's tradition of matriliny. Coming from matrilineal families, both Yvonne and Tanya should have been given to their mothers' relatives. Their stay with paternal relatives explains more the theory that they had to be sent outside the family.

Another instance where cultural practices play a role in domestic servitude is the influence of "godparents" in the lives of their "godchildren." It is traditional, and honorary, for Ghanaians to name their children after family and non-family members. Often, parents would name their children after people in appreciation of their favorable influence at some time in their lives. Children are also named after people in the belief that the child would grow up to take after their godparents in terms of economic successes, respectability and good behavior. Therefore, parents usually choose admirable and successful people to name their children after.

Others name their children after relatives or friends out of love. Such is the case of Patricia whose parents named her after her father's half-sister. At age 10, her aunt, the person she was named after, came for her to help her go through formal education. Patricia's mother suggested that they allowed her to stay with her aunt out of the love her husband had for her, rather than the possibility of not being able to take care of their daughter. Unfortunately, this aunt sent Patricia to her daughter who needed a maidservant at Accra. Patricia did go to school, through the J.S.S., however, her aunt's daughter did not fulfill her aunt's initial promise of sending her to a good private school. Rather than 
being made to feel a part of her aunt's family, she remained an outsider, having very limited access to the family's resources while taking care of household and babysitting chores throughout the nine years that she stayed with them. She was also subjected to physical abuse. Her cousin and employer slapped her on the cheeks, at times with any object that she could lay hands on, at the least provocation. At the time of her exit from this servitude, she had an ear infection that had resulted from the beatings. When she completed the J.S.S., she had hopes of going to work as an apprentice in a hairdressing salon but her employer failed to pay the fees. Instead, she had to work in this employer's bakery without pay.

\section{CHAPTER SUMMARY AND CONCLUSION}

We observe from above that culture plays an enormous role in the enrollment of children into domestic servitude. Some of the reasons for the children's willingness to accept offers of domestic servitude point to this conclusion. The dominance of girls in domestic servitude stems from the notion that domestic or household responsibilities are feminine and therefore the work of women and girls. This is a cultural expectation. Some parents, employers and domestic servants told me that the duties of domestic servants are feminine and thus the domain of women or girls. Another aspect of this notion is the domestic servants' hope of learning these feminine skills which, according to them, will make them good wives. 
The girls' expectation of becoming financially able to learn hairdressing or dressmaking is another indicator of the role of culture in child domestic servitude. These are two occupations that are perceived to be feminine in Ghana. There are many male dressmakers, however, Ghanaians usually use the term of "dressmakers" to refer to women who earn their living by sewing, while referring to males in the same occupation as "tailors." In addition to that distinction, the Ghanaian tailor usually specializes in male clothing while the female concentrates on those for women. This observation may not be true for fashion designers who acquired their training from advanced training institutions such as polytechnics.

Finally and most importantly, I observed that this type of child labor emerged from an existing practice that ensured that children could live with older members of their extended families and be provided with skill training as well as formal education. This quest of economic independence for their young members lingers on today. Nevertheless, this relationship is no longer limited to adults and children who come from the same extended families. The pursuit of economic gains especially on the part of the employing households is an exploitation of this historical practice. 


\section{CHILD DOMESTIC SERVITUDE AS A HOUSEHOLD SURVIVAL STRATEGY}

As I pointed out in Chapter Five, child domestic servitude exists in Ghana today because its consumers have exploited a long standing tradition that evolved out of patterns of extended family relationships. Gradually, newly married women, or mothers, requested the services of non-family members with the promise of supporting them financially through education or skill training. In recent times when Ghana's economy became deteriorated following political instability and the onset of unsuccessful neo-liberal economic policies, the need for children as domestic servants took a new turn. While the demand for children to baby-sit or to keep the house in order that a mother could work professionally did not decline, patrons of domestic servants need them for the added responsibilities of keeping shops or hawking foodstuffs. This corroborates the theory of the multiple modes of livelihood discussed in Chapter One.

In the following subsections, I present observations about child domestic servitude as a means of survival strategy and outline benefits of domestic servitude to employers, domestic servants and their families. Although the families of child domestic servants benefit from the work of their young members, this dissertation does not support the theory that the survival of such families depend on the children's work. Rather, I argue that employers are the primary, and in some cases, the sole beneficiaries of child domestic servitude. The long hours of work performed by domestic servants and the lack of remuneration for 
some of them explain this assertion. In this chapter, I will also discuss domestic servants' responsibilities.

\section{ECONOMIC BENEFITS THAT ACCRUE TO EMPLOYERS OF DOMESTIC SERVANTS}

The practice of child domestic servitude in Ghana is economically beneficial to employers and to some extent, to the servants' family. Neo-liberal economic policies worsened poor living conditions in rural Ghana. Nevertheless, as the theory of multiple modes of livelihood suggests (Owusu, 2001), these policies impoverished urban households as well (Owusu, 2001). Consequently, both rural and urban residents have had to diversify their means of survival in order to cope with worsened living conditions. Domestic servants help employing households to generate incomes through petty trading or by taking responsibility of household chores while the female heads engage in full time employment outside the home. As for the domestic servants' families, their benefits derive from the reduction in household dependency ratios once their daughters leave home to work as domestic servants. In this section, I present the employing household's benefits from child domestic servitude.

Domestic servants are usually assigned three broad responsibilities.

These are exclusive household and babysitting chores; exclusive retailing responsibilities; and a combination of both. The type or combination of tasks that domestic servants perform, according to my observations from the data, depend on where they live and work. As I will explain very shortly, there are instances 
where employers in both urban and semi-urban communities live with two or more domestic servants in order that there will be constant supply of free labor for their petty trading. Although children live with other families in rural areas, my limited observations during this research indicate that it is very rare for them to be treated as domestic servants. Usually, they go to school and share household responsibilities with their hosts' children. They hardly suffer the outgroup positions that characterize domestic servants in urban regions. As outgroup members of the households that they work for, some domestic servants eat different foods, are not permitted to play like other children their age within the household, or to enjoy household entertainment facilities such as the television, stereos and games.

I observed from the qualitative data that urban or semi-urban employers who assign their servants both household and commercial responsibilities fit the principles of the multiple models of livelihood model. Commercial responsibilities and household chores that domestic servants engage in make it possible or easy for their employers to diversify their sources of income or to save the monies that would have been paid adult domestics for the same duties. Enyonam, for instance, first lived with and sold pastries for a teacher at Ho in the Volta Region (refer to Map on page 51). The husband of her current employer, a school teacher, was bedridden with stroke at Accra. Thus, while she kept a shop for this family, she also took care of the sick man and assisted with other household chores. 
Another employer relying on multiple modes of survival was a Kumasibased secondary school teacher who lived with Serwah and Afriyie who were mentioned earlier. She indicated in my interview with her that she went for domestic servants so they could sell bagged water for her. Afriyie was the first servant and sold at least $C 50,000$ worth of water a day. She was 16 years at the time of the interview and had been living with the current employer for five years. She dropped out of school before her recruitment. The employer had three young children; the oldest of them was six years at the time of the interview. The youngest was a year old. She decided to go for a second helper who would concentrate on the sale of bagged water to students while Afriyie did strictly household chores. She was, however, disappointed with Serwah's performance and so decided to switch their responsibilities - Serwah to carry out household chores while Afriyie sold the water. At the University of Cape Coast also, Mavis made and sold pastries for her employer while the latter worked as a full time teacher.

In semi-urban communities, domestic servants mostly work at their employers shops or hawked their wares or foods around town. At Tikobo \#1 in the Western Region, I interviewed four servants two of whom kept shops while the others hawked some type of homemade ice-lolly. Hawa, Ahmed's niece and recruit mentioned earlier in previous chapters was one of them. Like Serwah and Afriyie's employer, this employer had two servants. The second servant was 16 years of age when I interviewed her employer. She was eight at the time of recruitment. Hawa's employer had given birth and realized she needed another 
hand if she were to maintain her business. So Hawa was recruited purposely for the business while the older servant continued working around the house and on the employer's farm.

Even when households do not require domestic servants for commercial purposes, they derive net financial benefits from them. As I indicated earlier, the domestic servant's presence in the household makes it possible for the mother in the said household to take full time employment. A large number of the current domestic servants interviewed in urban centers took care of children and performed other household duties such as cleaning, cooking, doing the laundry and going to the market or shops while the female heads went to work.

Ordinarily, households can employ a paid adult to perform these duties and professionally. With the exception of domestic servants recruited through formal agencies, all the others are either underpaid or never paid at all for taking care of children, doing general household chores and for trading for the employing household.

Domestic servants in this research work 10 to 18 hours a day. Some of them work longer than that. They usually wake up before six a.m. Almost all of them sweep and dust as first chores. They take a break to prepare breakfast for the family and to get the children, if any, ready to go to school. The fortunate ones will then take a break till noon when they prepare lunch for the children. Otherwise, they continue with their chores. When everybody is gone, they clean the bathrooms, do the laundry, go to the market and come to prepare lunch and dinner. By the time they go to bed, it will be long past 10 p.m. 
Since age nine when she became a domestic servant, Samira for instance, woke up around 5 a.m. everyday. She first cleaned the house if it was her household's turn to do so and then went hawking. She helped to cook on her return from school, and then went back to her commercial activities. In the mornings, she sold rice, sugar or pastries. In the evenings, she kept a shop after cooking. In addition to mundane grocery stuff like seasoning and canned foods, she sold alcoholic beverages and cigarettes, even at age nine.

Patricia who lived with her godmother's daughter while going to school, helped with her bread-making business in addition to other household chores. When she completed the J.S.S., her cousin's promise of enrolling her in a hairdressing apprenticeship was never fulfilled because of the free services she provided in the bakery. I asked her if the experience there was not enough to make her a baker. She explained that she could not because she just ran errands for them, or helped them to knead the dough. As to what ingredients they add to the flour and detailed processes of making the bread, she was never allowed to learn them. At a very young age, Molly who went to live with her late father's friend and his family at age four had to clean and light the lamps in her benefactor's guesthouse where they also stayed. She said some of the guests liked her and so gave her tips. 


\section{Payment for Domestic Services}

From above, we observe that children sometimes receive skill training through their responsibilities as domestic servants. Although this dissertation does not condone child labor exploitation, it discovers that the trading and other responsibilities are skills that when learnt, can help the servants to become economically independent during adulthood. The potential for children to learn skills from these responsibilities make it easy to refer to them as positive children's work, using ILO's definition. Besides ILO's categorization of children's employment into positive and negative children's work as outlined in Chapter Two, it argues that

Children work because their survival and that of their families depend on it, and in many cases, because unscrupulous adults take advantage of their vulnerability. It is also due to inadequacies and weaknesses in national education systems. It is deeply ingrained in cultural and social attitudes and traditions (ILO C182: 11).

Contrary to this assertion, survival of the giving-families in this research is not dependent on their children's deployment into domestic servitude. By this assertion, I do not imply that the families of domestic servants do not in any way benefit from their children's work. Rather, I acknowledge the fact that the benefits accruing to them relative to those enjoyed by the children's employers tends to be infinitesimal, especially given the fact that some domestic servants do not get paid at all. Families of domestic servants enjoy the indirect benefits of being spared the burden of taking care of their young members when they live in and work for other households. In the past, families had the additional privilege 
of saving the cost of puberty rites when their children's employers took up the responsibility to organize and sponsor this initiation ceremony.

According to the data, child domestic servants do not usually have any income to give to their families. We learn in Chapter Four that where there is a non-formal recruiter involved, the family's chances of seeing their child's income when a contract is curtailed is even minimal. The reason is that their recruiters, as Chapter Four suggests, save the money for them while they re-assign them to new households. Only a few of those who arrange to receive monthly incomes can think of sending monies to their families, but that is rare.

For working 10 to 18 hours a day providing the services that I outline above, the highest paid among the non-formally or informally recruited current domestic servants received $\mathrm{C} 90,000.00$ (approximately $\$ 9.50$ ) a month at the time of this research. Among those recruited through formal agencies, the minimum pay was $\mathrm{C} 150.000$. Other employers in the non-formal and informal categories of recruitment choose to pay their servants off at the end of their service. The usual means of payment when payment is deferred towards end of their contracts, as indicated earlier, is an enrollment in an apprenticeship, either to become a hairdresser or a seamstress.

Employers justify their underpayment of domestic servants with the claim of taking care of their basic needs and medical expenses. In Akosua's statement quoted on page 38 , her employers promised to pay her $\mathrm{C} 80,000$ a month besides her living expenses. Akosua's employers kept her salaries for her but she could always request part of it for her personal effects, usually clothing. 
Others employer that I interviewed also emphasized their daily expenses on their servants.

At the time of recruitment, employers usually arrange with families or the servants themselves the method of payment and how much it should be. On average, employers agree to enroll them in the apprenticeship after two years of service. Depending on the location and the background of the trainer, the entry fees can range between C200.000 and C1 million (i.e. between $\$ 22.00$ and 120.00). In the case of domestic servants who choose dressmakers, employers must also provide sewing machines and the necessary tools to start the training. Domestic servants who opt for hairdressing may receive hairdryers, otherwise they may buy them on their own once they complete their training and become independent.

Employers who agree to pay a monthly wage usually give the correct amount should the domestic servant decide to leave at any time. Derrick's and Sophia's recruits who were discussed earlier received the exact amount due them when they chose to curtail their employment, albeit underpayment.

In this research, only one of the participants, Akosua who lived with a university faculty, ever sent part of her pay to her mother. After living with her employers for seven months, she collected four months' pay and sent an equivalent of one month's pay, i.e. C80,000 (about $\$ 9.50$ ) to her mother who was then taking care of her two year old son. This kind of gesture did not occur often among my respondents. For those who stay long enough to be enrolled in an apprenticeship, they hardly have anything for their families back home. When 
domestic servants curtail their service before apprenticeship, they stand a chance of returning home with some money and clothing or a sewing machine. On rare occasions do families usurp such resources without saving them for the domestic servant.

Current domestic servants who had lived with other families before told me that their parents saved their previous remuneration, which was always meager, so it could be supplemented for their skill training sometime in the future. When I met Enyonam, she was living with her third employer. Both previous employers gave her a sewing machine each when she was leaving. She was lucky - throughout her previous servitudes, she had remained in school until she completed the J.S.S. When I asked what she did with the two machines, she told me her mother was keeping them for her. Later, she said they were looking for somebody to sell one to, but she was not sure how much it would sell for.

Indisputably, families enjoy the benefit of not feeding or bearing the living expenses of another household member once they are recruited into domestic servitude. The hope of the child coming home with money and equipment to start learning a trade is also comforting. This hope is almost universal in the respondents. Some of them had lost both parents and had no caretaker. Angela went into domestic servitude for the reason that both parents were deceased. As stated above, her uncle who succeeded her father had his own children to cater for. As a minimum wage earner, he could not adopt and fend for his brother's ten orphaned children. Consequently he looked for an employer for her. When she 
had to be recruited the second time but did not want to accept the offer following her bitter experience with her former employer, her uncle successfully persuaded her, under the circumstances of financial constraint, to rescind her decision.

What I heard most in those interviews were: my parents could not further my education; I had no one to take care of me; my mother could no longer finance my education and poverty, among other similar statements. Once recruited into domestic servitude, parents, guardians or the extended family members responsible for the upkeep of the children, given these reasons, are relieved.

At times, generous employers send remittances to their domestic servants' parents. As stated in Chapter Four, Kate's employer gave a certain amount of money to Derrick for her mother. Gloria's employer indicated that she gave old clothing to her father when he visited them once. Gloria recalled that her employer gave some money to her father but, she was not sure how much it was. Other generous employers saw their servants' off in a manner that would invariably benefit their families. Mrs. Biney told me at one time, she performed the puberty rites of her domestic servant, saving the family the cost and drudgery of sponsoring it themselves. As she described it, "we bought so many things and gave them away, cloths, towels, shoes and cosmetics, and... a lot of things. Powder, they specified the quantity to buy." At the time of the interview, Hawa's employer was preparing to send her 16 year-old-servant away. "At the moment, I have one who might be going away at the end of the month. She is old. I have therefore been making the preparations so that when she gets home, her mother 
would realize that her child lived with a good person," she said. She did not specify what she was giving to this servant, but did confirm they would include a sewing machine, clothing and money.

Given devout adherence to cultural practices such as initiation ceremonies in the years before the 1980s, remuneration for the older generation of domestic servants in this research took the form of puberty rites sponsorship. These older women specified that girls who lived with relatives before the 1970 s and 1980 s did not expect any form of remuneration for their services, not even when they were not enrolled in formal education. The only exception was Esther who shared a lot in common with post 1980 domestic servants and had to live with three employers and usually agreed with them on the method of payment before her recruitment.

Many are those who run away without informing their employers, and by so doing forfeit all their entitlements. There are instances also where employers refuse to give any gifts or payment package to their outgoing servants even when they have overstayed the usual two years, if the employers think they are leaving on a bitter note. Samira and Patricia, two former domestic servants who experienced this situation, lived with two relatives. As discussed earlier, Patricia lived with her first cousin. Her father's sister after whom she was named came for her with the intention of living with her. It turned out that she wanted someone for her daughter, Patricia's cousin, to live with. Patricia was 10 years then and at the time she was returning to her parents, had already turned 20 years. Her cousin refused to fulfill her promise of sending her through an 
apprentice training to become a hairdresser because the servant's mother had paid them a visit, the first in nine years. On her part, Samira lived with her mother's stepmother for four years. When her mother decided to come for her, her step grandmother's daughter was highly upset and so advised her mother, the 'employer,' to take everything from the girl. She went back home with nothing.

More often than not, employers never fulfilled their part of the agreement to send off domestic servants after two to three years. It took at least four years for employers to enroll their servants in any type of apprenticeship, contrary to the usually agreed period of two years. Hawa's employer lived with her other servant, the 16 year old, for a period of 8 years before thinking of buying her the machine and other tools to send her off. Afriyie lived with her employer for close to five years before being enrolled in an apprenticeship. Soon after her enrollment, her employer advised that she quit because of reports that the trainer did not show up regularly. Afriyie's employer promised to re-enroll her at a different place, but that can take a while. Another respondent at Nungua, a suburb of Accra, started a hairdressing apprenticeship after six years of service. Her employers did not have to pay the usual fees because the trainer is related to them. That notwithstanding, the servant had to stop the training at the request of her employers, their reason being that the hairdressing salon was too far from home. They promised to look for another trainer closer to their house for her, but after six months, this respondent had still not heard about it. 
While these employers could have good intentions stopping their servants from going to work, there could be other motives. For instance, hairdressing and dressmaking apprentices are as much exploited by their trainers as the employers that they live with. Apprentices perform many chores some of which are unrelated to their training for their bosses (Marguerat, 2000) and therefore they have to be at work very early in the mornings, and sometimes leave late at night. Most of them go to work six days a week. Hairdressing and dressmaking apprentices in Ghana help their trainers in the provision of services to their clients. This they have to do as part of their training, without any remuneration. In the rural areas, some apprentices perform household chores and go to the farms for their trainers. The implication of this is the unavailability of the servant to provide free domestic services for her employer. Hence, the real motive behind their withdrawal could be the retention of lost hours of free services, rather than distance or trainer's absenteeism.

As already indicated, domestic servants, other than those recruited through the formal agencies, were either underpaid or never paid at all. The end of service package comprising sewing machines and cash for those who opted for that and were able to stay till the end of their agreed period, the monthly pay of $\mathrm{C} 50$ to $\mathrm{C} 90,000.00$ that those who opt for monthly pay receive; or the partial pay package employers give them should they prematurely abrogate their service contracts, is not commensurate with the amount of labor and the number of hours that they put in. 
Worst is the experience of those who curtail their contracts and lose everything due them. In conclusion, that families give their children into domestic servitude in order that such families would survive is a myth, at least for the participants in this study. Most of them are not paid, and when they do, they, their employers or recruiters save the savings for them. Interviews with the servants, their parents, recruiters and employers confirm that families receive very little, if anything at all, from their children's servitude. Employers, on the other hand, use domestic servants to cut costs or to generate incomes to supplement their household's resources. Therefore if there are any economic benefits from domestic servitude, the sole beneficiaries are the employers. Until children serve longer than the agreed period or live with numerous employers, they might not be able to start learning any skills unless their parents foot that bill.

\section{How are Child Workers Paid: Statistical Evidence}

The qualitative analyses concluded that domestic servants are paid in cash at the end of the month if they were recruited through formal or non-formal agencies or mostly at the end of their service, usually in kind. Although the survey asked questions about how child workers are remunerated and who the beneficiaries are, the findings do not indicate that many of the respondents were paid for their services. According to the data, only $1.5 \%$ of the 17,034 participants get paid for their services. As much as $98.5 \%$ do not get paid at all. Analyses of bivariate association between child domestic servitude (defined by 
relationship to the head of household and having response variables "not related" and "other relatives") and how they are remunerated evidence a somewhat strong relationship between these two variables, given a Cramer's V score of .553. A Pearson $X^{2}(4, N=60)$ of $18.35(.001)$ also reveals a statistically significant relationship between child domestic servitude and how they are paid.

Table XI: Bivariate Association between Method of Remuneration and Relationship to Head of Household

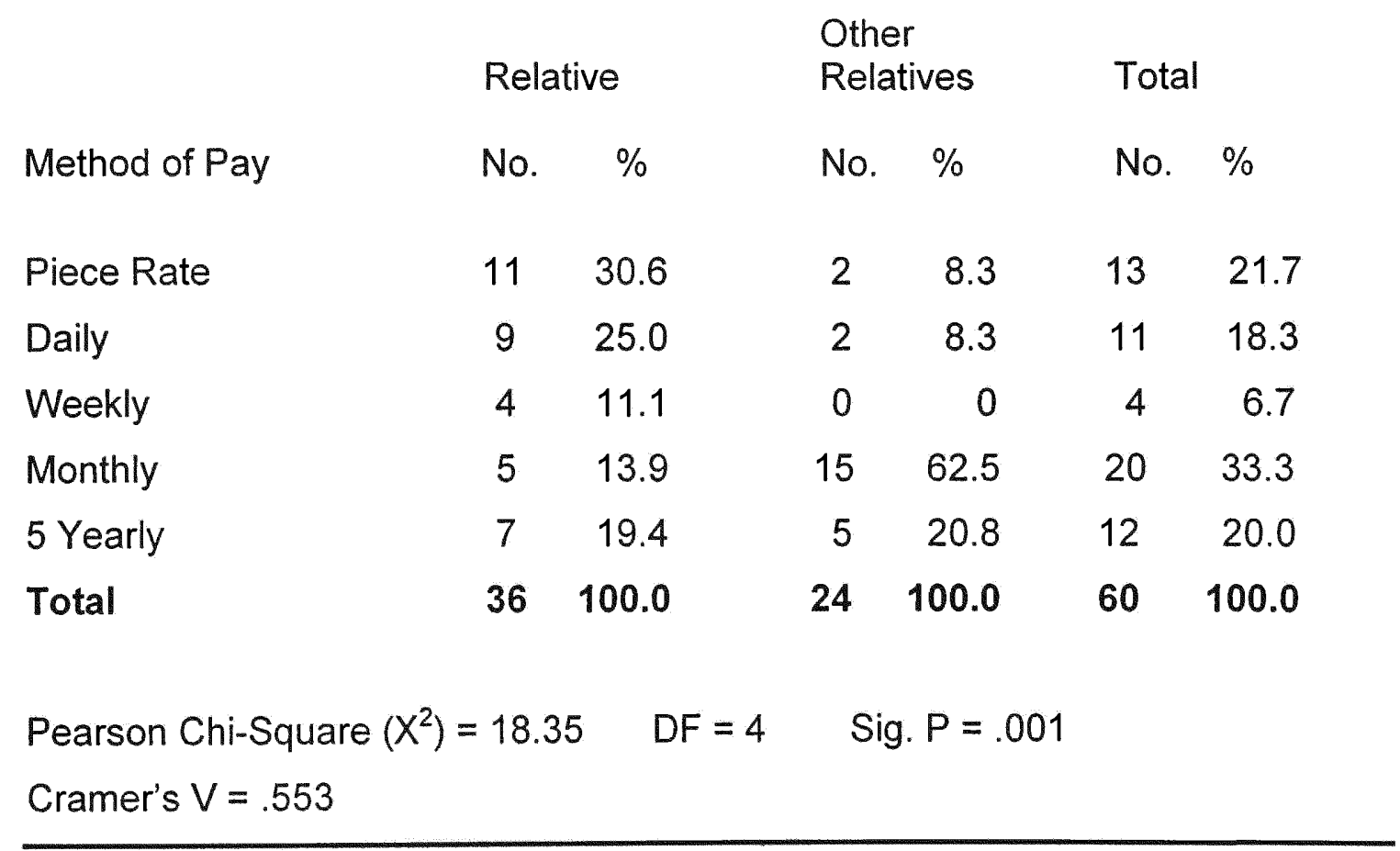

Findings, which are presented in Table XI, corroborate observations in the qualitative analyses that domestic servants are not regularly compensated for their services. Only $60(4 \%)$ of the 1,445 who were defined as domestic servants are paid. Of those 60 domestic servants, $60 \%$ live with other relatives while the 
other $40 \%$ live with non-relatives. The implication of this is that domestic servants who live with their relatives are more likely to be compensated for the services that they provide.

We observe further in that table that nearly $30 \%$ of those who live with other relatives and a little over $8 \%$ of those who live with non-relatives are remunerated on a piece rate basis. Additionally, a third (33.3\%) of domestic servants is paid regularly on a monthly basis, while $20 \%$ is paid after five years. Of all those who live with non-relatives, $62 \%$ (i.e. $75 \%$ of those who are paid on a monthly basis) are paid regularly on a monthly basis. The statistical data does not provide any information on how respondents are recruited, therefore, very little inference could be made and related to conclusions made from the qualitative analyses. Conclusions that respondents who are recruited through formal and non-formal agencies are more likely to be paid regularly at the end of the month cannot be replicated with all certainty at this stage of the analyses because of the lack of information on how participants in the survey were recruited.

\section{WHY DOMESTIC SERVANTS PREMATURELY LEAVE SERVITUDE}

Earlier, I suggested that domestic servants who did not stay until employers decided to enroll them into the training of choice usually stood the risk of not receiving payment for their services. This observation notwithstanding, some domestic servants preferred to leave, at times without informing their 
employers and thus losing their benefits. Out of the 44 current domestic servants in this research, 19 had lived with more than one family. Seven of the former domestic servants of the post-1980 era lived with at least two households before settling down. Given that some respondents knew they stood the risk of losing their accrued incomes or the chance of being enrolled into an apprentice training should they leave on their own, I asked questions about what drove them to take such risks. Using the microeconomic theory of utility maximization, I concluded that until domestic servants and their families realize their goals for being a part of domestic servitude, young women and children will continue to reenroll as servants. This subsection describes conditions that prompt domestic servants to desert their work.

While disparate experiences and reasons contribute to their exit from any household, the domestic servants' or their parents' hope of the former accumulating adequate incomes or sufficiently pleasing their employers so as to find the means to learn a type of trade was very common. It was so rare for any other respondent, current or past, apart from Lily (see Chapter Eight on slavery), or even their parents, to categorically state that they needed to be in servitude otherwise their families could not feed them. I observed that they derive their spirit of persistence in servitude from this hope of future economic independence, rather than from current gratitude from basic necessities such as food, clothing and shelter. Families are more concerned about their offspring's future independence, rather than incomes to be acquired through exploitation of the latter's labor. Given this background, one might wonder why girls would leave 
domestic servitude when the goals are yet to be realized. The rest of this subsection examines the causes of premature departure among domestic servants.

Generally, three things drive either the employer or the domestic servant to end the "contract" prematurely. When employers ask their servants to leave prematurely, it is usually because of the latter's contact with or intentions to visit their families and or the employers' suspicions of their servants having boyfriends. These are besides the usual dissatisfaction with the servants work. The servants also leave either because their employers' house is quiet, for sexual abuses or if they are wrongfully accused. I did not meet any respondent who had to leave for long hours of hard work or for non-payment of services. Only one servant disclosed her intentions to leave at the end of the second year if by then she had not been registered to learn a trade. Earlier on page 113,1 quoted an employer's description of how she sent off a servant who ran away because her new home was so quiet. Emelia's employer also told me her fourth servant decided to leave because their university bungalow was too quiet for her.

Amina is another servant who ended her agreement with two employers first, because one place was too quiet for her and second, because her employer advised her to leave after she decided to pay a visit to her parents. I met her in a small village in Ashanti Region. She had already lived with three families since dropping out of school. Two months after living with the first person in Kumasi, the Ashanti Regional capital, she ran away without informing them. Her reason for leaving is that the place was too quiet for her. She said she was also afraid to 
be there all by herself. She was not paid for her services. Although the second employer paid her $990,000.00$ a month, her parents thought the priority was her formal education, and so sent for her after a couple of months. Amina did not stay long in school and after dropping out the second time, went to live with the third family. Her employer agreed to pay her off at the end of two years. Just around the end of her second year, she requested to visit her parents to celebrate the Easter festivities with them. The man's wife suggested that she packed her things so she would not return. She received half a million cedis (approximately $\$ 80.00$ ) for staying with them for two years. Patricia's experience earlier mentioned is similar to this. Her cousin asked her to go away after Patricia's mother paid her a visit, and as I emphasized earlier, the first time in nine years.

An isolated case of an employer asking a servant to leave without any provocation on either side took place soon after Mrs. Grace Coleman, the erstwhile MP, was indicted. This particular employer was a member of parliament also. According to Helene, the former domestic servant, this employer lived with about six domestic servants at the same time. One day, without anything having changed in the house or any of them offending her, she told them she could no longer live with any of them and so arranged for them to go away. She made Helene return to her grandmother in the company of "a certain woman," Helene explained. Helene, a J.S.S. graduate, went to live with this MP at the age of 16 . It was arranged that after two years, this employer would provide her with the sewing machine and some money to enable her learn 
a trade. The MP did not give her these things when she made arrangements for someone to send her back to her village. In my interview with her grandmother, I learnt that they were making plans to contact the MP for the sewing machine and if possible, some money for the enrollment fees. She stated further that if this plan failed, they would find another alternative to get Helene to start the training; however, living with another household as a domestic servant was out of the question.

Earlier, I made reference to a third person that Derrick had recruited but whom I could not interview. This servant lived in the same household as Michael, another recruit of Derrick's, and James, the cousin of their employer. According to the employer's wife, this servant was being sexually abused like her predecessors, and in a telephone call to Ghana sometime in 2004 , I learnt that she had run away as a result of the sexual assault. This girl was 15 at the time of the interview. I could not interview her because she was almost always busy whenever I went to visit her. I held brief discussions with this employer's wife whenever I visited to get one of the servants to interview. She was not in favor of her husband recruiting girls to help around the house because they always complained of his sexual harassment and left. As indicated previously, Michael came from the same village as this girl and their recruiter, Derrick. Their employer accused James of having connived with the girl to escape. The former thought his employer was never pleased with anything that he did subsequent to that accusation and so ran away some weeks later. Both of these domestic servants were not remunerated for their services. 
This employer is one of two males who were directly involved in the recruitment and responsibilities of their servants. There were two families in which the men arranged for the recruitment of their domestic servants. Usually, the women did that and kept contact with the children. They seemed more responsible for the domestic servants and houseboys than the men were. The other man was the contact for Amina's recruitment. Therefore, she made reference to him as the employer and to the woman as "the man's wife." Usually, I heard "the woman's" husband.

Two other respondents, Doreen and Akesi, also encountered sexual harassment and left their employers as a result. On page 113, Doreen's first experience with an attempted sexual assault was discussed. This man was never successful in his attempts to abuse her sexually, but after discussing it with a neighbor, she realized it was necessary for her to run away before his wife found out and ended her marriage. She escaped in the night, sleeping behind wooden structures until she was able to hail a taxi at dawn for her hometown. Prior to that, she had been raped at age 15 , when she lived with her father's female cousin while her mother sojourned in the Ivory Coast. The culprit was her aunt's son who beat her in addition to the sexual assault. She reported this to her aunt who later found out that she had become pregnant as a result. They took her to the hospital for an abortion and from the hospital her aunt beat her again, mercilessly. The boy also beat her again, telling her that she should not have mentioned his name. Doreen reported this abuse to her father. When her aunt found out, she threw her out of the house around 12.30 in the night. 
While Doreen might have been right anticipating that reporting the man's constant harassment to his wife could have jeopardized his marriage, she could have been kicked out in a similar manner as her aunt did should she have report the attempted abuses. For Akesi did exactly that and was dismissed by her female employer. Akesi lost her businessman father when she was young. Her paternal uncle inherited the business but refused to finance her and her siblings' education. Thus she and her sister ended up in servitude. Her first employer's husband lived in another town and visited from time to time. On one such visit, he attempted to rape her. She did not keep this to herself but reported it to her female employer. She confronted her husband who advised that the girl be sent away because he did not want her serving the household anymore. From there, she looked for another employer without consulting any of her family members. Her mother searched for her for sometime and just as she was about to make a report to the Police, she got word of her daughter's job in a local restaurant in a village miles away from the Western Region where they come from.

Besides sexual harassment, verbal and physical abuse seemed to run through most of the interviews. Unless the employer respected the servant and understood the circumstances leading to their choice of such jobs, they "... are treated as though..." they "... are not a part of the human race, that you weren't born," to quote Angela, one of the current domestic servants.

Domestic servants left servitude for many reasons. However, as the above discussions under this subsection point out, servants are more willing to stay than leave because of the hope of being paid for the services rendered. I 
argue that if girls accept to go into servitude for any particular reason, such as to be able to learn a trade eventually, they are more willing to stay to fulfill that objective before leaving. In the event that they leave for any reason, they are almost always willing to go into servitude again. Leaving one family at any time before starting an apprentice training or the servant's accumulation of adequate funds to start such training therefore tends to be temporary. In the next subsection, I employ the statistical data to analyze the combination of factors that may determine employee satisfaction with their jobs and employers.

Respondents were asked to indicate whether they considered their relationships with their employers to be good or bad. This dependent variable of "relationship with employer" was recoded from an original variable whose responses were "good", 'bad", "other" and "don't know", into "good" and "bad". The rest of the variables were defined as missing and thus excluded from the analyses. The findings show that 154 as against 7 respondents were satisfied with their employers. Given the constant nature of the relationship between servants and their employers, no further tests were conducted on the level of respondents' satisfaction with their employers. To some extent, this observation probably corroborates the qualitative data finding that respondents are willing to stay with their employers until they received pay for their service. On the contrary though, this constancy does not support the qualitative data finding that almost every respondent thought they live under slavery conditions. 


\section{CHAPTER SUMMARY AND CONCLUSION}

Domestic servitude exists in Ghana because of cultural and economic reasons. Although the practice of children living with other families has existed in Ghana for a long time, one observes that cultural factors explained domestic servitude in the past. Today, economic factors drive families to either send their children to live with other families or to look for children to live with as domestic servants. The giving families' benefit from child domestic servitude was more indirect that direct. Contrary to assertions in the literature, we observe that families benefited from their children's servitude only to the extent that they do not have to feed them or provide the funds for their children to learn some trades. The employing family, on the other hand, derives both direct and indirect benefits from the use of children's labor in their households. The direct benefits result from the use of these children in petty trading, while the indirect benefits accrue from the nonpayment or underpayment of child domestic servants. Although children have to stay longer than agreed before being allowed to start learning a trade, those who are patient enough are able to realize this long term goal. Those who are not able to stay long enough to be put through the training return to their parents, are reassigned households, or their parents foot the bill of apprenticeship. To conclude, the only real beneficiaries of domestic servitude are not the children's families or the victims themselves, but the employing households. 


\section{CHAPTER SEVEN}

\section{RELATIONSHIP BETWEEN FORMAL EDUCATION AND THE INCIDENCE OF CHILD DOMESTIC SERVITUDE}

Education is probably the major path through which a population's children can be protected from labor exploitation and slavery. Education can keep children busy and thus exclude them from any type of employment. While many children are engaged in what Chapter Two identifies as positive children's work, one observes that un-enrolled children of school going age are more vulnerable to exploitation than those in school. I observed from the qualitative data that rural children are more likely to stay out of school than children in urban Ghana, and thus are more vulnerable to labor exploitation. Resource availability, parents' occupational and educational backgrounds and their expected values of education influence children's participation in formal education. If for any of these reasons, or others, children do not access formal education, they become readily available for work and thus for exploitation, and in some cases, for exploitation under slavery conditions. This chapter discusses the relationship between formal education and the incidence of child domestic servitude, as well as the influence of parental values on their children's educational participation. 


\section{GHANA'S FORMAL EDUCATIONAL SYSTEM}

The 1998 Children's Act defines the Ghanaian child as all persons below the age of 18. The minimum working age is, however, set at 15 years. Before this age, the child is required by law to remain in school. Children usually start school at age six. Until 1987 when Ghana launched its Education Reform Program, there was a 17 year pre-university schooling. This reform program reduced the pre-university school to 12 years. Currently, there is a 6-3-3-4 schooling structure in Ghana. Children are required to spend six years in primary school, three years in junior secondary school (J.S.S.), another three years in senior secondary school (S.S.S.) and four years in the university. The first nine years of schooling, that is the primary and junior secondary schooling, makes up the mandatory basic education for all children. Article 25 of Ghana's 1992 Constitution stipulates that the basic education shall be free, compulsory and available to every child.

While this constitutional provision follows from principles of the Convention on the Rights of the Child discussed in Chapter Two, there are also concerns about Ghana's development goals and the relationship between that and the quality of it's children. Ghana's development goal is to attain a middle income status by the year 2020 . Specific goals and strategies have been outlined in the development plan 'Ghana Vision 2020'. Indisputably, the quality of its children and adults will be instrumental for the attainment of those specific goals.

Prominent among them is a set of educational goals which, although an end in 
themselves, will contribute to the attainment of the other goals of the plan. The educational goal is to "ensure that all citizens, regardless of gender or social status, are functionally literate and numerate, at the minimum" (Ghana's Vision 2020). Two programs have been launched towards these objectives. These are the Girl's Education Unit and the Free Compulsory Universal Basic Education (FCUBE). The FCUBE program covers three broad objectives. These are improvements in the quality of teaching and learning; improvements in management efficiency; and improvements in accessibility of basic educational facilities.

In line with the third objective of the FCUBE, the Ghana Education Service established the Girls' Education Unit in 1997. This Unit is responsible for the development of women's social capital. Among other things, this Unit aims at increasing enrollment of girls in basic education to equal that of boys; reduce drop-out rates among girls in primary schools from $30 \%$ to $10 \%$ and $21 \%$ to $15 \%$ among girls in junior secondary schools; and to enhance an increase in the transition rate of girls from junior to senior secondary schools by $10 \%$ by the end of the FCUBE program. In addition to improving their levels of educational attainment, improvement in women and girls' social capital will advance their bargaining power, their self-confidence and their decision-making power.

In 1998 when these educational objectives were established, $31 \%$ of the population who were aged 15 and above could neither read nor write. In the years that followed, Ghana saw slight improvements in its literacy rates. In 2001, for instance, only $27.3 \%$ of the population aged 15 or older could neither read nor 
write. In 2002, there was a further reduction to $26.2 \%$. The declining trend of the nationwide literacy levels reflected in the statistics for females. In $1998,40 \%$ of the female population who were aged at least 15 years was literate. In 2001, only $35.5 \%$ of females aged 15 or older could neither read nor write. This rate fell to $34.1 \%$ of the female population aged 15 and over in 2002 . A 1998 estimate shows a $56.8 \%$ net primary enrollment of the relevant age group. While gross primary enrollment between 1996 and 2002 stood at a higher rate of $80 \%$ of all school going ages (The World Bank Group, 2004); primary school enrollment for males stood at approximately $84 \%$ with a significantly lower level for females at $76 \%$. In 1998 , the estimated net secondary (high) school enrollment was $26.1 \%$ of the relevant age group.

\section{PARENTAL INFLUENCE IN THE EDUCATION OF THEIR CHILDREN}

Although it is the constitutional right of every Ghanaian child to receive at least the basic education, socio-economic conditions facing their parents and certain traditional beliefs, as suggested in Chapters Two, Four and Five, deny the child that right to education. Parental occupation and economic backgrounds are among other factors that determine children's vulnerability to child domestic servitude in Ghana. For the purpose of this dissertation, I categorize the economic standards of households into three. The first category consists of the middle class through the richest members of the research population.

Expatriates, state officials and employees occupying middle through upper level 
managerial positions in state and private enterprises fall under this topmost category. The second category consists of people occupying lower level managerial positions as well as self-employed men and women who make basically the same levels of incomes. According to the World Bank, an estimated $60 \%$ of Ghana's population lives above the poverty line. These constitute the two levels of economic standards conceptualized here. The other $40 \%$ are the poor, an estimated $60 \%$ of which live in rural regions. They are the source of free labor supply for domestic servitude in urban regions.

With the exception of the only male parent who participated in this study, none of the parents of the domestic servants in this research ever had high income jobs. This father who was on pension at the time of this interview had worked as an electrician in the Electricity Corporation of Ghana. He finished the elementary school and learnt to be an electrician through an on-the job training program. His wife whose father had to send her into domestic servitude in order for her to avoid the misery of living in rural poverty and becoming a fishmonger had no job when I did this interview. Five of the parents and relatives who lived in the coastal areas of Central Region were fishmongers and or petty traders who sold cooked food. All the parents I interviewed in Ashanti Region were peasant farmers. They never went to school.

For the other domestic servants whose parents I could not interview, I observed from their responses that they were mostly petty traders and or farmers. With the exception of three fathers who were a chainsaw operator, a Pentecostal church pastor and a local gin brewer, all their fathers were farmers. 
The women were mostly farmers, but a few of them doubled as petty traders in addition to farming. Neither the parents nor their children could estimate their annual, monthly or weekly incomes. Farming is seasonal in those communities and until the cocoa or food crop seasons, these families subsisted on few farm produce without regular financial incomes. The petty traders dealt in foodstuffs and household consumables such as soaps, canned foods and seasoning. The women from the coastal areas were usually fishmongers.

Rural parents in Ghana usually were either never enrolled in formal education at all, or dropped out sometime before graduation. In this research, there was only one elementary school graduate among those that I interviewed. The others were never enrolled at all or dropped out in the primary school. This partially explains why most of them live primarily on farming, petty trading and fishing or fish-mongering. Ghanaian petty traders usually sell foodstuffs, convenient items, stationery and clothes. Their own educational backgrounds notwithstanding, some of them do appreciate formal education's potential of social mobility, and insist on their children's full participation. Kwame Nkrumah, the first President of Ghana, in his biography, emphasized that his mother's incessant struggle to get him to be interested in school compelled him to stay eventually. In contemporary Ghana also, both rural and urban parents strive to get their children to be interested in formal education. Some children are virtually dragged and caned to stay in school. In this research, seven of my respondents said that their parents at times removed them from servitude so they could go 
back to school, although they preferred to not be in school for poor performance or for punishment by teachers.

This observation does not hold for all cultural areas in the research population though. Among the rural residents of coastal Central Region, for instance, a person's chances of going to school depended more on their parents' occupation. As some teachers told me, school children preferred to go fishing or to trade in fish at the beach rather than be in school. If their fathers were primarily fishermen and owned fishing equipment, first and second male children were more likely to drop out of school to learn this trade in their early childhoods. In this context, it is probable that the parents might not have experienced the positive impacts of formal education in their own lives and so have very little value for it.

\section{EDUCATIONAL RESOURCE AVAILABILITY AND ACCESSIBILITY}

Like the main factors explaining child labor in general, cultural and economic reasons are also responsible for low levels of formal education in girls, and thus for higher levels of the incidence of labor exploitation among them. This interaction between culture and economic factors both at the local and international levels (Bhavnani, Foran and Kurian, 2003; Young, 1984; Goheen, 1991; Mikell, 1997) makes child labor exploitation gender biased. In addition to parental involvement, children's educational chances also depend on resource availability as well as the cultural and the economic environments of the group in 
question. To help understand the economic terrain of the research population, I define three types of communities, namely rural, semi-urban and urban communities. .Rural populations are very small, usually below 5,000 . For instance, Hwidiem, one of the rural communities where I interviewed some former domestic servants and some parents, has a population of about 400 . Semi-urban communities have populations of at least 5,000. Urban centers, usually humongous, tend to be overcrowded especially in poor shanty towns. Their populations are at least 50,000

Rural communities are the poorest, having very limited if any social amenities or infrastructure. They do not have potable or pipe borne water, health facilities and in some cases, primary education. One of the rural communities that I visited during this research had a school with only six grades, from primaries one through six. Beyond the sixth grade, students have to walk two miles to attend school in the nearest village. Some of these villages do have locations near tarred or asphalted trunk roads, this making it easier for their residents to access nearby towns and cities for schools, hospitals and markets by car, truck or bus. At times, rural residents have to travel to and from nearby towns on foot. The poorest among them are located in the hinterlands and are joined to other communities by small, untarred laterite roads. Residents of these communities usually do not have their own vehicles but use private commercial vehicles most of which operate once a week. In Table XII below, as much as $44 \%$ of children who were never enrolled in school indicated that their parents could not afford it. Although the data does not provide respondents' reasons for 
their lack of interest in schooling, the distance, the fact that it might worsen the financial burdens of their families and the lack of general educational infrastructure could be the reasons.

\section{Table XII: Why Some Respondents Never Attended School}

Regions

Parents cannot afford

School too far

Not interested in school

Family does not allow schooling

Illness/diabled

Both parents not alive

Father not alive

Mother not alive

Other

Total

\section{Frequency Percentage}

1,264

44.2

526

18.4

488

17.1

142

5.0

60

2.1

8

3.0

37

1.3

30

305

2,680
1.0

10.7

100.0

To make matters worse, rural schools lack basic resources and this make learning in them more difficult and unpleasant. Rural schools in Ghana have very few teachers if any at all, and some of them are hardly qualified to teach. Recent studies show that 652 schools in Ghana are short of teachers (Berlan, 2004). Furthermore, some of these rural teachers have been observed to cash in on the labor of their pupils (Cabanes, 2000). Robert Cabane (2000) notes that many rural teachers in former African colonies use their pupils' labor by asking them to fetch water or wood for the former's personal use. The interplay 
between the lack of resources, the use of pupils' labor by rural teachers and the need for children to walk miles to nearby villages and towns to attend J.S.S. could prevent children from participating fully in formal education.

Consequently, they drop out because of poor academic performance. Ten of the domestic servants who participated in the qualitative study said they dropped out of school because they did not do well academically. Rather than walk miles to nearby villages for school, such children preferred living in urban areas with other families than to go through formal education without any expected outcomes. Even among those who finish school in such rural regions, levels of educational achievement are usually low. Research shows that an estimated $60 \%$ of children graduating from junior secondary schools in rural Ghana do not acquire basic literacy (Berlan, 2004).

It is not disputable that poverty exists in urban regions of Ghana as well as it is in rural areas. Isaac Owusu and the World Bank and other reports confirm that standards of living for urban residents in the research population worsened following poor implementation of economic policies. Nevertheless, access to formal education in urban areas tends to be more favorable than it is in the latter. The use of children in farming or fishing, although prevalent in urban areas, is not as intense as it is in rural regions. Both parents and children place more emphasis on education than the latter's involvement in farming or fishing activities.

Additionally, availability of good infrastructure and learning aid in the cities make it easier for children to keep abreast with their school work if they really 
want to. The implication of this is that urban children, irrespective of their family's socio-economic backgrounds, are less likely to experience labor exploitation or to live in servitude without receiving at least the basic education. Accra, the capital of Ghana and all regional capitals such as Cape Coast, Kumasi and Takoradi, on the other hand, are urban communities. These towns have advanced educational institutions such as polytechnics and universities. Unless district capitals had such advanced centers of learning, they were considered semiurban. The semi-urban communities have characteristics of both the rural and the urban. Most of them have secondary schools and a few formal organizations such as banks, police stations and post offices. The most developed amongst them have hospitals and schools affiliated with universities. The poorest among them have no secondary schools but can boast of health posts, which are markedly different from conventional hospitals. Health posts usually do not have medical doctors but medical assistants or nurses. Some of them are just overgrown communities, encountering higher rates of urbanization without any matching improvements in social amenities. While both the urban and semiurban communities have most of the amenities and infrastructure (such as telephones, paved roads, post offices and potable water), necessary to make living conditions bearable, overcrowding and overpopulation diminish these advantages for most residents.

Table XIII is the mean distribution of school educational participation in the various regions. From that table, we observe that Upper West, Upper East and Northern Regions (the poorest regions in the country) experience the lowest 
rates of school participation in Ghana. We notice further that although educational attainment tends to be generally low, children from poor regions are less likely to be enrolled.

A cross-tabulation of regions by educational participation also shows a statistical relationship between these two variables. A Pearson Chi square (54, $N=16,967)$ of $3,037(.000)$ is highly significant at $\alpha=.05$. Nevertheless, a Cramer's $\mathrm{V}$ score of .23 shows the strength of this relationship is less than moderate. From Table XIV, we observe a marked distinction in formal educational participation between Northern, Upper East and Upper West Regions on one hand, and all other regions on the other. As Map II illustrates, these three Northern Regions, namely Upper East, Upper West and Northern Regions are the poorest in the country. School participation in Greater Accra Region where the Capital of Ghana is located is highest with over $86 \%$ current enrollment. Volta Region has the lowest enrollment rate, $80 \%$, among these other seven regions. Ashanti, Central, Eastern, Brong Ahafo and Western Regions show a near independent relationship because their enrollment rates ranged closely between 83 and $84 \%$. Northern (51\%), Upper East (59\%) and Upper West (54\%) Regions have the lowest range of participation rates.

The regional statistics shows that Greater Accra, a traditionally patrilineal society, has the highest rate of school participation. Greater Accra, as noted in Chapter Four, has many educational facilities and opportunities that are more accessible than other regions. Besides, it is the ultimate destination for many 
migrants. Hence, unless specified, we cannot determine if respondents are Accra indigenes, i.e. the Ga ethnic group, or immigrants from other parts of the country or elsewhere. The three regions having lowest rates of school participation are all patrilineal. As the poorest in the country, they are the least attractive to migrants. Nevertheless, it is more reliable to blame the low rates of educational participation on poverty both at the household and regional levels, than on lineage.

Table XIII: Mean Distribution of Regional Educational Participation

Regions

Western

Central

Greater Accra

Volta

Eastern

Ashanti

Brong Ahafo

Northern

Upper East

Upper West

Total
Mean

.9128

.9240

.9373

.8657

.8990

.9180

.8951

.5351

.6222

.5764

.8243
Frequency

1,721

1,395

2,008

1,370

1,951

2,623

1,762

2,394

127

772

17,025 


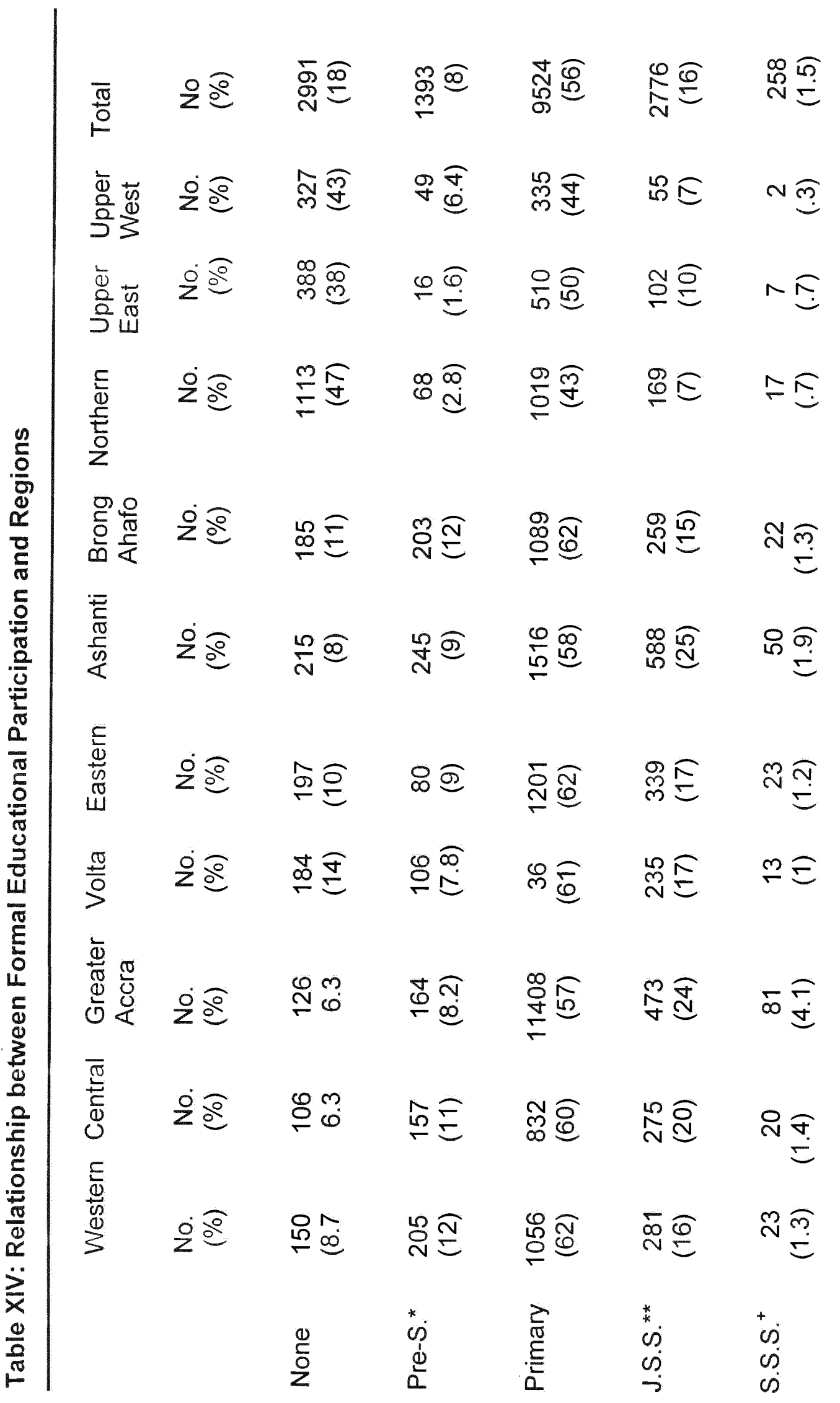




$$
\begin{aligned}
& \text { 더 - }
\end{aligned}
$$

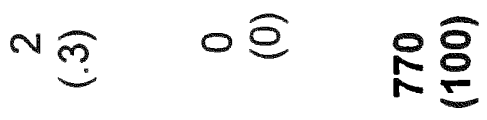

$$
\begin{aligned}
& \text { N ํํ } \\
& \text { oอ oอ } \stackrel{\substack{m \\
\text { iे }}}{0} \\
& \text { - ํํㅇ 용응 }
\end{aligned}
$$

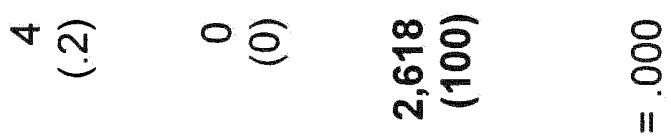

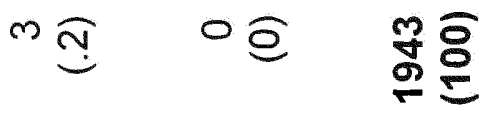

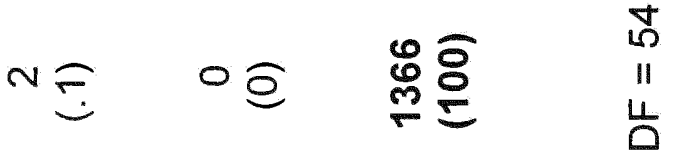

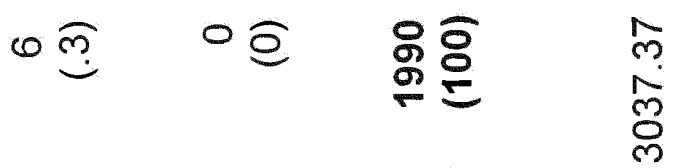

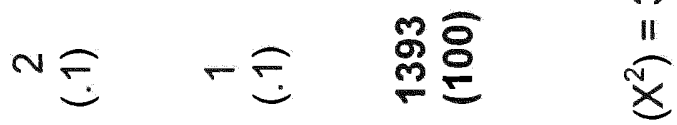

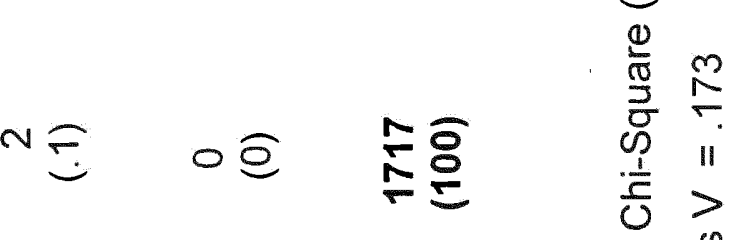

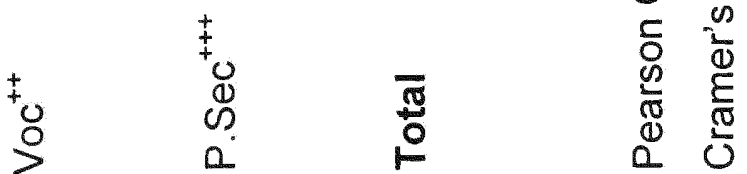

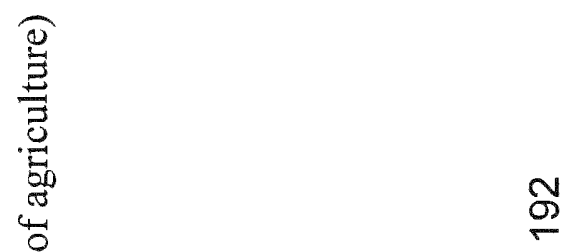


Table XV: Bivariate Association between Highest Level of Education and Type of Community (Rural or Urban)

Urban

Rural

Total

No. $\%$

No. $\%$

No.

$\%$

No Education

397

6.2

2,594

24.5

2,991

17.6

Pre-School

588

9.2

804

7.6

1,392

8.2

Primary

3,689

57.7

5,837

55.2

9,526

56.1

Junior Secondary

$1,488 \quad 23.3$

1,287

12.2

2,775

16.4

S.S.S. or higher

236

3.7

47

.4

283

1.7

Total

$6,389 \quad 100.0$

$6,398 \quad 100.0 \quad 10,569$

100.0

Pearson Chi-Square $\left(X^{2}\right)=1327.3 \quad$ DF $=4 \quad$ Sig. $P=.000$

Cramer's $\mathrm{V}=.280$

Formal education in urban communities in Ghana is vastly different from what exists in rural regions. Ghana's urban public schools are usually not in as deplorable states as those in rural regions, making the basic education more attractive to children of school going age. Hence, it is easier for urban children in the research population to receive at least the basic education. Beyond the basic education also, such children are less likely to end up in domestic servitude. Those urban children who do not make it to traditional senior secondary schools are able to access other alternatives - commercial, vocational or technical schools, which are hardly available in rural Ghana. These are parallel to senior secondary schools but are terminal in the sense that their graduates learn skills in office administration, secretaryship, book keeping, carpentry, draftsmanship 
and catering services, and look for jobs when they finish. Even when available, rural parents might not be able to afford these other alternatives.

From the discussions above, we observe that both rural and urban children are at the risk of child labor exploitation. However, given infrastructural availability and accessibility in urban, and to some extent semi-urban regions, rural children are more vulnerable to labor exploitation, comparatively. While low rates of enrollment and higher dropout rates exist among rural children, urban residents who are able to complete the basic education are also able to access other educational alternatives that make it possible for them to learn trades. Besides formal education, parental occupational and educational backgrounds as well as processes of socialization enshrined in some cultural practices determine the vulnerability of children to labor exploitation and slavery.

Children in some cultures learn trades associated with their cultures or geographic locations. Rural children devote part of their times to working on farms or in fishing, besides regular household chores that they have to perform. Boys and girls who are still enrolled in schools undergo these processes of socialization on weekends and after school on week days. Given that most villages do not have electricity, children of school going age have very limited time to do school work when they return home from farming or fishing. In an undergraduate research that I did among a fishing community in the Central Region of Ghana, I found out that fishing was more important than school to the children and their families. Therefore, they refuse to sacrifice daylight for children's school work. This problem is further compounded by the lack of 
educational facilities and teachers in rural Ghana. Conclusively, they perform badly in school even if they had adequate facilities and teachers to assist them in their studies. This partly explains why $60 \%$ of Ghana's rural school children, as pointed out in Chapter Two, have received no basic literacy (see Berlan, 2004).

\section{RELATIONSHIP BETWEEN FORMAL EDUCATIONAL PARTICIPATION AND CHILD DOMESTIC SERVITUDE}

From above, we observe that formal education is not equally accessible to Ghanaian children. The inability of parents to afford educational expenses even in the face of the FCUBE and the need for some children to travel to nearby communities to go to school, at times, make formal education less attractive to both parents and children. These also make child domestic servitude a lucrative venture among rural families. In the following paragraphs, I discuss these relationships in detail.

I observed from the qualitative data that there are a number of domestic servants who graduate from the junior secondary school (J.S.S.) and go into domestic servitude as a means of accumulating the necessary resources to go into some type of apprentice training, usually dressmaking or hairdressing. A very limited number of them go to school while living in servitude. There were others also who either drop out of school or are never enrolled at all. They also see domestic servitude as a means of escaping rural life and learning a trade. 
There were 16 current domestic servants who had dropped out of school, while 18 had completed the J.S.S. Three of them were still in school. Seven current domestic servants never went to school. The oldest person in this sample, the 28-year-old woman I met at one of the two employment agencies that I discussed in Chapter Four was also the only domestic servant respondent who had completed the senior secondary school (S.S.S.). The second oldest person was 25 years old and was recruited at the age of 15 . She dropped out of school.

The younger generation of former domestic servants was more educated relative to their older counterparts. Only one of the eight post-1980 former domestic servants dropped out of school. The rest had all completed the J.S.S. Some of them attained or were about to attain their long term goal of becoming hairdressers or dressmakers. Only one of them had completed her training as a dressmaker at the time of this research. Samira had gone back to school and was in her final year at a fashion institute. Her mother was funding her. Only one of them had become pregnant. The rest were in training to become hairdressers or dressmakers.

It is based on the observation that child domestic servants were almost always out of school during servitude that this dissertation concludes that education seems to be a major means to ending or alleviating child labor exploitation. We observe also that children who successfully complete the J.S.S. might use domestic servitude as a stepping stone to learning trades that will enhance their independence as adults. This dissertation therefore asks the 
research question: what is the relationship between formal educational participation and child domestic servitude? This question sought to determine the role that education plays in the incidence of child labor in general and tested the hypothesis below.

\section{Hypothesis Test 4: Bivariate Association between Formal School} Participation and Child Labor

$$
\begin{gathered}
H_{0}=\begin{array}{l}
\text { no association exists between formal school } \\
\text { participation of children and child labor; }
\end{array} \\
H_{1}=\begin{array}{l}
\text { an association exists between formal school } \\
\text { participation of children and child labor. }
\end{array}
\end{gathered}
$$

The dependent variable of child workers consisting of all children who were younger than 18 years (regardless of their relationship to the head of household) was crosstabulated with formal education. According to Table XVI, as much as $90 \%$ of children who have never been to school, $90 \%$ of those who are still attending school and nearly $84 \%$ who left school live with their own parents or grandparents. Only $8 \%$ of those who never attended school, $7 \%$ of those still attending school and $12 \%$ of those who left school already live with other parents. Given a Pearson $X^{2}(4 ; N=16,742)$ of $112(.000)$, this relationship is statistically significant at $\alpha=.05$. A Cramer's V score of .08 indicates, however, that the association between formal education and child labor, considering all child workers including those who live with their parents and grandparents, is a very weak one.

The dominance of children living with their parents or grandparents, either as current students, past students or children who were never enrolled is 
probably a reflection of the pattern of respondents' relationship to the household heads in the data. A majority of the respondents in this research live with their own parents and it is more likely for them to go to school than for those who live with non-parents. In order to control for this dominance of children who live with their parents in the determination of the association between child work and participation of children in formal education, the dependent variable of child servants which excludes children who live with their parents and grandparents was cross-tabulated with children's schooling.

Table XVI: Bivariate Association between Formal Educational Participation and Child Workers (Including Those Who Live with Own Parents)

\begin{tabular}{|c|c|c|c|c|c|c|c|c|}
\hline & \multicolumn{2}{|c|}{$\begin{array}{l}\text { Never } \\
\text { Attended }\end{array}$} & \multicolumn{2}{|c|}{$\begin{array}{l}\text { Attended } \\
\text { Still attending }\end{array}$} & \multicolumn{2}{|c|}{$\begin{array}{l}\text { Past } \\
\text { (Left School) }\end{array}$} & \multicolumn{2}{|c|}{ Total } \\
\hline & No. & $\%$ & No. & $\%$ & No. & $\%$ & No. & $\%$ \\
\hline Child/Grandchild & 2,629 & 90.0 & 11,791 & 91.8 & 815 & 83.5 & 15,235 & 91.0 \\
\hline Other Relative & 238 & 8.2 & 904 & 7.0 & 116 & 11.9 & 1,258 & 7.5 \\
\hline Non-Relative & 53 & 1.8 & 151 & 1.2 & 45 & 4.6 & 249 & 1.5 \\
\hline Total & 2,920 & 100.0 & 12,846 & 100.0 & 976 & 100.0 & 16,742 & 100.0 \\
\hline \multicolumn{3}{|c|}{ Pearson Chi-Square $\left(X^{2}\right)=112$} & \multicolumn{2}{|c|}{$D F=4$} & \multicolumn{2}{|c|}{ Sig. $P=.000$} & & \\
\hline
\end{tabular}

The findings are presented in Table XVII. Nearly $82 \%$ of all servants who never attended school live with other relatives, while $18 \%$ of them live with nonrelatives. Also, $86 \%$ of those who are attending school live with relatives, while $14 \%$ live with non-relatives. Additionally, $72 \%$ of those who left school live with 
relatives, while $28 \%$ of them live with non-relatives. In this test also, the incidence of children living with relatives tends to be high, and that is true whether the child was never enrolled in school, is currently enrolled or has left.

These findings do not provide enough evidence to support the hypothesis given a Pearson $X^{2}$ of $(2, N=1507)$ of $19.6(.000)$. Hence the $H_{0}$ of no association between formal education and child labor/servitude is rejected at $\alpha=.05$.

Moreover, there is a weak relationship between child servitude and formal education given a Cramer's V score of .114 .

Table XVII: Bivariate Association between Formal Educational Participation and Child Servants (Excluding Those Who Live with Own Parents)

\begin{tabular}{lrccccccc}
$\begin{array}{l}\text { Relationship to } \\
\text { Household Head }\end{array}$ & \multicolumn{2}{c}{$\begin{array}{l}\text { Never } \\
\text { Attended }\end{array}$} & \multicolumn{2}{c}{$\begin{array}{c}\text { Attended/ } \\
\text { Still attending }\end{array}$} & $\begin{array}{c}\text { Past } \\
\text { (Left School) }\end{array}$ & \multicolumn{2}{c}{ Total } \\
& No. & $\%$ & No. & $\%$ & No. & $\%$ & No. & $\%$ \\
Other Relative & 238 & 81.8 & 904 & 85.7 & 116 & 72.0 & 1,258 & 83.5 \\
Non-Relative & 53 & 18.0 & 151 & 14.3 & 45 & 28.0 & 249 & 16.5 \\
Total & 291 & 100.0 & 1,255 & 100.0 & 161 & 100.0 & 1,507 & 100.0
\end{tabular}

Pearson Chi-Square $\left(X^{2}\right)=19.58 \quad$ DF $=2 \quad$ Sig. $P=.000$

Cramer's $\mathrm{V}=.114$

\section{RELATIONSHIP BETWEEN LINEAGE, FORMAL EDUCATION AND CHILD LABOR EXPLOITATION}

The following tests are similar to the above. The difference is that these tests focused on the relationship between lineage, formal education and the incidence of child labor. The first test, which follows the above, will examine the 
relationship between matrilineage and patrilineage on one hand and formal education on the other. Earlier in Chapter Five, I controlled for regions given that ethnic groups are usually conglomerations of many regions, and also for the argument that some regions were more endowed with social amenities and infrastructure than others.

\section{Hypothesis Test 5: Bivariate Association between Lineage and Formal} School Participation of Children

$$
\begin{aligned}
& H_{0}= \text { no association exists between lineage and formal school } \\
& \text { participation of children; } \\
& H_{1}= \text { an association exists between lineage and formal school } \\
& \text { participation of children. }
\end{aligned}
$$

As Table XVIII illustrates, there exists an association between formal education and lineage in Ghana. The data shows that children from matrilineal ethnic groups in general are more likely to go to school than those from patrilineal backgrounds. A total of $17.7 \%$ of children from both matrilineal and patrilineal backgrounds do not go to school. However, only $5.7 \%$ of matrilineal and $27.4 \%$ of patrilineal children never attended school. A little over $76.4 \%$ of all children are enrolled in school. Among children from matrilineal backgrounds, a little over $87.2 \%$ are enrolled in schools, while $67.5 \%$ of patrilineal ethnic groups are enrolled in school. A Pearson chi square $((2, N=16412)$ of $1313.46(.000)$ establishes that there is a relationship between lineage and school enrollment among children in Ghana. This finding is statistically significant at $\alpha=.05$. The hypothesis of no association is thus rejected. A Cramer's $V$ of .283 indicates 
however that the strength of this relation, although significant, is less than moderate.

Table XVIII: Bivariate Association between Lineage and School Participation

Matrilineal Patrilineal Total

Status of Enrollment

No. $\%$

No $\%$

No. $\%$

Never attended

424

5.7

$2,476 \quad 27.4$

2,900

17.7

Still attending

6,791

87.2

$6,098 \quad 67.5$

$12,532 \quad 76.4$

Past/left

$524 \quad 7.1$

456

5.0

980

6.0

Total

$7,382100.0$

$9,030 \quad 100.0$

$16,412100.0$

Pearson Chi-Square $\left(X^{2}\right)=1313.46$ DF $=2 \quad$ Sig. $P=.000$ Cramer's $V=.283$

The same hypothesis, (i.e. $H_{0}=$ no association exists between lineage and formal school participation of children; $H_{1}=$ an association exists between lineage and formal school participation of children) was tested using the highest level of education attained by respondents as the dependent variable. Given a Pearson chi square $(6, N=16,354)$ of $1441.46(.000)$, the data evidence a statistically significant bivariate association between lineage and educational attainment. As Table XIX suggests, the largest number of children are either in the primary school or they drop out at that level. The test of bivariate relationship between educational attainment and lineage reveals that $60 \%$ of matrilineal and $52 \%$ of 
patrilineal children who are aged between five and 17 years are either in the primary school, or drop out at that level. Together, they constitute nearly $60 \%$ of all the children aged below 18 but who are at least five years old. .

Table XIX: Bivariate Association between Lineage and School Attainment

\begin{tabular}{|c|c|c|c|c|c|c|}
\hline \multirow[b]{2}{*}{ Satisfaction } & \multicolumn{2}{|c|}{ Matrilineal } & \multicolumn{2}{|c|}{ Patrilineal } & \multicolumn{2}{|c|}{ Total } \\
\hline & No. & $\%$ & No. & $\%$ & No. & $\%$ \\
\hline No Education & 424 & 5.8 & 2,745 & 27.5 & 2,900 & 17.7 \\
\hline Pre-School & 795 & 10.8 & 549 & 6.1 & 1,344 & 8.2 \\
\hline Primary & 4,415 & 60.0 & 4,732 & 52.6 & 9,147 & 55.9 \\
\hline Middle/JSS & 1,566 & 21.3 & 1,123 & 12.5 & 2,689 & 16.4 \\
\hline Secondary/SSS & 149 & 2.0 & 103 & 1.1 & 252 & 1.5 \\
\hline Voc/Tech/Commercial & 9 & .1 & 12 & .1 & 21 & .1 \\
\hline Post secondary* & 1 & 0 & 0 & 0 & 1 & 0 \\
\hline Total & 7,359 & 100.0 & 8,995 & 100.0 & 16,354 & 100.0 \\
\hline \multicolumn{4}{|c|}{ Pearson Chi-Square $\left(X^{2}\right)=1441.33 \quad D F=6$} & \multicolumn{3}{|c|}{ Sig. $P=.000$} \\
\hline
\end{tabular}

*(Agricultural/Nursing/Teacher training)

\section{CHAPTER SUMMARY AND CONCLUSION}

This chapter analyzes the relationship between formal education and the incidence of child domestic servitude in Ghana. It gives an overview of the structures of education in Ghana and shows that children who are most vulnerable to domestic labor exploitation are those who complete the basic 
school without advancing to high school, or drop out without graduating. Existing research indicates that girls are more likely to drop out of school than boys. As Michael Kevane (2004) notes, girls are more likely to leave school to work because their parents consider them to be more generous with their incomes (Kevane, 2004; Mikay, 1997). Additionally, girls are less likely to remain in school in many cultures of the research population when resources are scarce because of the belief that they would one day end up as housewives. Parental educational backgrounds and their occupations are also important factors that determine school participation of children. I argued in this chapter that highly educated parents had good jobs and so could afford their children's education. Finally, I noted that the urban children had more access to formal education and so are less likely to be exploited in domestic servitude. 


\section{CHAPTER EIGHT}

\section{CHILD DOMESTIC SERVITUDE: THE QUESTION ON CONTEMPORARY SLAVERY}

Chapter One of this dissertation points out conclusions that this research draws about the processes of recruitment, methods of remuneration of domestic services and how such payment is put to use. These observations were located in theory to determine if the domestic servants who participated in this research are slaves. This chapter is a presentation of the findings about the statuses of the domestic servants as far as slavery is concerned.

I categorized the theories from the literature into two, namely those that explain old slavery and those explaining contemporary slavery. Theories explaining old forms or traditional slavery emphasize permanent ownership of the slaves, their transferability, high levels of profitability and the fact that old slavery was legally permitted. From the limited literature on contemporary slavery, I considered processes of recruitment, the level of maturity and ability of the domestic servants to give consent to their recruitment and responsibilities. To sum it all up, the use of force and violent control of the victims' labor (Bales, $2000 ; 1999)$ and their lack of consent and maturity (Barry, 1984) are the basic characteristics of contemporary slavery that this dissertation looked for in the domestic servants. Additionally, I employed prior distinction between positive and negative children's work, which I outlined in my MA thesis, to critically assess the position of my respondents. In both Convention 182 (Eliminating the 
Worst Forms of Child Labor) and the Practical Guide to that Convention (the Handbook for Parliamentarians No. 3: Eliminating the Worst Forms of Child Labor) the ILO describes positive children's work as functional to their socialization, personal and economic developments and to their families.

Although the processes of their recruitment did not make the domestic servants in this research slaves, a majority of the current and former domestic servants, some of their employers, the parents and the Director of Ghana's Social Welfare did confirm that some of them live under slavery conditions. They are physically and verbally abused, they are not paid, some of them cannot go back to their parents for fear of being sent back and most importantly, they do not have their free will while living as domestic servants in other households. Although I could not define them as contemporary slaves, I categorized them as quasi-slaves because they are not free labor; some of them are not even mature or knowledgeable enough to give informed consent.

\section{DOMESTIC SERVANTS WHO ARE NOT CONTEMPORARY SLAVES}

Going by conventional processes of obtaining slaves, this dissertation could have defined eight of both current and former domestic servants of my respondents as slaves. These are respondents who were too young to be knowledgeable about domestic servitude and to be able to consent to their employment. The use of force characteristic of slavery acquisition in general, however, is non-existent among the rest of the domestic servants. They were 
usually aware of the potential exploitation and abuses that domestic servants sometimes encountered. In fact some of them had accepted domestic servitude positions three to four times prior to their current or most immediate recruitments. Their awareness or previous experiences in servitude and its inherent abuses could not stop them from remaining in or reentering servitude; most of these servants are driven by severe economic conditions and cultural expectations to live servitude. They are the quasi-slaves. I conceptualize the quasi-slaves of Ghana's domestic servitude as persons who, although obtained through what might be described as acceptable means of recruitment, suffer verbal and physical abuses, stand a high probability of not being able to leave servitude for fear of losing their accrued incomes or for the lack of the freedom to do so, and who generally suffer forms of slavery-like exploitations and abuses

The youngest of my respondents was Hawa, the eight year old shop keeper whose paternal uncle sent her into domestic servitude. Using Barry's definition alone, I could have qualified Hawa as a contemporary slave in its absolute terms. Hawa became a domestic servant at the age of six. Indisputably, this servant was too young to be working as a shop attendant. Nevertheless, this dissertation cannot define her as an absolute slave because of the circumstances surrounding her recruitment and the answers that she provided about her reasons for being there. My interview with her uncle and recruiter also gave indispensable pointers to my understanding of Hawa's position. 
According to her employer and her uncle, sending Hawa into domestic servitude was her father's approach to ensuring her economic security. Hawa never went to school because her father could not afford it. Her stay with her parents might not have made life any worse for them; however, she would have remained out of school and with no hope of learning a trade sometime in the future. Therefore, when her father sent her into domestic servitude, he was looking for an avenue to ensure that his daughter will eventually learn a trade to become economically independent during adulthood.

Furthermore, Hawa did not experience any of the enslaving treatments that other servants had to endure. Hawa understood why she was working for the shop owner. She told me that she was there to help her for sometime and at the end, be provided the means to learn a trade. Her employer also stated that she was committed to sending her into an apprentice training when the time came. As this case and those to be discussed presently exemplify, families intend for their children to attain certain skills towards their personal and economic growth. However, the fact remains that this poor child is not a beneficiary of some of the many rights of children; most importantly she lost her childhood to poverty and thus did not experience the joy of living with her own parents. It is a catch-22 experience for these domestic servants.

Lily is another young respondent who shared similar economic backgrounds as Hawa. She was also six at the time of her recruitment. Lily's mother made the request for the daughter to become a domestic servant in the employer's household in Accra. She had already spent six years in that 
household when I met her. According to this employer, she accepted to live with Lily primarily because she needed someone to keep her mother company. Soon after her recruitment, the employer sent her to school.

Unlike Hawa who appeared so content with her new household, Lily wept intermittently during the interview for missing her mother so much. When asked if she wished she were back home with her parents and siblings, she responded in the negative, explaining that her mother "could not feed" her. Conclusively, her mother could not finance her formal education either. Like Hawa, even at such a young age, Lily understood the circumstances surrounding her stay with a different family in Accra. In addition, she understood the discriminatory treatment that her employer gave her vis-à-vis her grandchildren. As she pointed out, she wished she could play like the other children, but could not anytime her employer was home. Like Hawa, Lily also lost her childhood to poverty, although in her case, she was fortunate to receive formal education.

In a follow-up call to Ghana, I learnt that Lily's employer had sent her back to her parents for petty thievery. They described the scene of her return as pathetic because she cried bitterly, refusing to stay behind. After a few weeks when the employer visited that town again, she found Lily in a miserable condition; she had dropped out of school and was washing dishes with her mother in exchange for food. Out of pity, this employer took her back to Accra so she could reenroll in formal education.

Given that economic independence and growth for Lily and Hawa was contingent on their stay with other families, and given also that they were not 
abused and forced to work under violent threats, I could not classify them as contemporary slaves in absolute terms. This observation notwithstanding, we cannot disagree with the fact that these two young girls have been denied their childhood, do not live in families that necessarily give them the love and care that they need, and they have been denied the right to live with their own parents. These observations about the domestic servants I categorize as quasi-slaves also characterize those respondents who were recruited before age 13 .

In addition to these servants, there were some young adults who were mature and knowledgeable enough to consent to their recruitment and assignment into domestic servitude and thus could be classified neither as contemporary nor quasi-slaves. Nonetheless, they are also victims of the laborrepressive system under discussion. They are exploited labor. Derrick's recruits, most of whom had completed the basic education, satisfied this level of knowledgeability and could negotiate their incomes with their employers and recruiter. Moreover, they had received the basic education and so had that right provided, usually by their own parents. Indisputably, they are victims of exploitation in the sense of working long hours without a commensurate level of remuneration, if paid at all. Many of these victims of exploitation seemed content with their statuses as domestic servants. One of them is Serwah.

I spoke to Serwah in one of the teacher's bungalows in a Kumasi-based Secondary School. She was very pleasant and told me she was very happy she had agreed to come to the city. I visited her village but could not get her mother to interview. This was a small village, of about 320 residents. There was no 
pipe-borne water. Residents had to walk about two miles to nearby streams to get water. There were no shops or markets, except a small wooden kiosk where a woman sold a few canned foods and fried yams. Residents carried their farm produce to the roadside to sell to motorists who cared to stop. There were no hospitals or health posts. The highest class in the only school was the sixth grade, and children had to walk if their parents could not afford the transport fare to the nearest town to go to school. Parents who were better off, and there were just about four households at that, did not allow their children to start the primary school in this village at all. As a parent told me, teachers in this school hardly reported to teach.

Considering this type of community where she originally lived, I understood why Serwah was so pleasant towards me and happy that she had migrated to the city. Serwah's recruiter consulted the former's mother to ask permission for her daughter to go and live in Kumasi. Her mother gave her approval. When asked what she would have done if the mother had refused to allow her to travel, Serwah indicated that she would have run away. She was very pleased with her employer, although she had never been paid for her services. There were many other current domestic servants who were very pleased to be living in other households in the cities, the lack of pay notwithstanding. Given their level of content, maturity and the fact that they had received the basic education in most cases, I concluded that they were neither contemporary nor quasi-slaves but exploited labor. 


\section{CONTEMPORARY SLAVERY: PERCEPTIONS OF SOME DOMESTIC}

SERVANTS

The domestic servants discussed above are not contemporary slaves in absolute terms. Unfortunately, I could not say the same thing for every respondent in this research. Some of them wept mercilessly while narrating their abusive experiences in domestic servitude. They wished they could return home, but some of their parents would not permit it. In this subsection, I discuss some of the domestic servants that this dissertation identifies as contemporary slaves. As pointed out earlier, I will relate the domestic servants' experiences, the methods and beneficiaries of pay and whether or not they are able to willingly exit contemporary to definitions of slavery in general, and those of contemporary slavery in particular.

As Esi's father put it when I paid him a visit in his hometown, she was his daughter, and if she returned home today, he was going to send her back the next day. Esi was 18 years at the time of this research and as a young adult, could have voluntarily left this family, but her father's decision was final. As suggested in Chapter Four, this parental decision making role in such instances was almost universal among these respondents. Serena is another domestic servant whose living and working conditions confirmed her as a contemporary slave. The first time she lived with somebody, she was only five. This was an extended family member who lived alone with the respondent. Serena started school while living with this woman. She kept her extended relative's small 
convenient stall when she got back home from school. She had to return to her mother because this woman's boyfriend left her and thieves broke into the stall, making away with the wares. Serena's current employer came to see her mother in the company of another woman, probably a recruiter, but she could not tell. This employer promised to send her back to school, but she should live with her for sometime. Serena said the time promised had already passed, but there had not been any mention of her going back to school.

She kept a convenience store in front of the woman's home, a compound house that she shared with several other families. She wept almost throughout this interview. She wished she could go back home, but could not tell her employer. She was waiting for her mother to visit one day so she makes her aware of the treatment she is going through. Unfortunately, she had no contact of her mother's, and at 17, could not find her way to her mother's home. What upset her most were her employer's husband's incessant verbal abuses whenever she refused to give him part of the sales. Usually, he referred to her as a slave who had been given to them as a gift. There were four children in this household. The oldest was 23 and the youngest 12 . They were either in school or learning a trade.

Selasie is another servant that this dissertation identified as a contemporary slave. At 13 years, she did not know her parents and could not tell where she had come from. The only thing she knows about herself is the fact that she is an Ewe, given that she speaks the Ewe language. That, however, is her employer's native language too and so it is possible she learnt it from her; 
she came to live with her when she was about three years old. Selasie has nowhere to go should she decide to leave servitude. In the first place, she does not have her actual family's background and in the second place, she is a minor and so cannot become independent without finding herself in the streets. Selasie looked so timid and withdrawn during my interactions with her. She looked and behaved far younger than the 13 years. In the interview, she told me about the physical abuses that she suffers from her employer. Unlike other servants though, she could tell me all her experiences without shedding a tear. I assumed that having lived and experienced such abuses from so young an age without knowing how it feels like to live in a loving family, she had no past to use as a reference. She could not share the nostalgic feelings that other domestic servants had about their families and villages.

Two of these three domestic servants, Selasie and Serena, qualified as contemporary slaves because of the processes of their recruitment. Most of the other servants as well as Esi and these two were enslaved through their working conditions, the treatment that they receive from their employers and the fact that they cannot exit servitude. Like Esi, almost all respondents in this research including employers and the two government officials that I interviewed identified the way employers and their families treated domestic servants as enslaving. The domestic servants further expressed the fear that their employers may not put them through any skill training before or after they leave servitude.

When asked if they considered themselves or domestic servants (in the case of non-domestic servant respondents) as slaves (or to explain who a slave 
is), a majority of domestic servants, employers and recruiters responded in the affirmative but with an emphasis on the treatment meted out to some of them.

The following are some of the responses by some current domestic servants:

Esi:

I sometimes feel I have no one, but when I visit my sister, she talks to me... I don't have my peace and freedom in this house, but when I visit my sister, she understands my pain and worries, so she is usually able to comfort me.

Mansah: it is so pathetic the way children who live with other families are treated.... Yes, some of them are.... They hit the slave with anything they could lay hands on - shoes, spatula - and when their children speak, the slave should not be around. The woman's children could ask you to hand-wash their underwear for them, the woman herself could give you her underwear to wash. These things make you a slave.

Kate: $\quad$ They are [slaves] since they also serve, but we've referred to them as house-girls so... someone who has been brought to work (pauses) around the house.

Joy: Like they're living with people whom they have bought them.

Anna: Oh, those who live with other families ... given that the children live with them, they make slaves out of them. The 'hosts' can do anything with the child living with them.

Emelia: To me they are not... the Bible says if your sister is in difficulty, help her...some people will tell you they will help you, but when you live with them, they maltreat you...

Gladys: Not that they are slaves, but if you consider the way that they are treated, you might think they are slaves... they treat their children differently from their helpers, and what their children would do that won't attract any punishment, the helper would be punished for the same offense.

Paulyn: Someone who is assigned work that she can't do.

Paula: Those who live with some people... she lives with somebody and works for the person. 
Stephanie: Some families are poor and ... they help those with money so they will support them. So when you do anything bad and they insult you, they tell you that you are a servant or a slave...

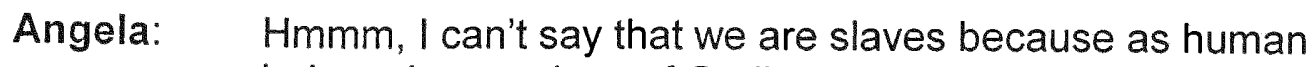
beings, I am a slave of God's... we are slaves for sure... because we are treated as though you are not a part of the human race, that you weren't born. But our parents suffered the same way as the others to bring us forth, but because of something.

Rita: Someone who lives with other families.

Edna: $\quad$ Some of them... there are those parents who do not let their children do anything in the house. It is the child who lives with them who does everything. This makes the child a slave.

Ingrid: $\quad$ Some of them... it means that the person they live with doesn't treat them like her own children.

Former domestic servants also put it this way:

Patricia: She treated me in a way that made me feel I was not human... because I served them ... a slave, I think is someone who has been brought to serve another person or groups of persons.

Helene: $\quad$ Yes some people are... like a maid... someone who helps with household chores, etc... yes, the woman made me a maid.

Margaret: It all depends on how you are treated. Some people could take you to be their own children. So it is all dependent on the attitude of the person who lives with you.

Samira: Someone who lives with somebody and serves that person. Such a servant is made to do things or go places where their own children will not be allowed to go.

While the processes of recruitment are generally significant in the conceptualization of any slavery relationships, these responses reflect Kopytoff's 
ideas on the processes of dehumanization and rehumanization. Although these responses do not support the notion of dehumanization, which starts from the moment the domestic servant is recruited, respondents agree that after recruitment, they are dehumanized. As discussed in the introductory chapter, domestic servants lose their identities as daughters, sisters, students or family members and therefore have to reorient themselves about their statuses. They have to learn new attributes that come with their new identities as domestic servants. For instance, they must realize that they cannot go to bed because they are sleepy - they can do that only when they complete their chores for the day. Additionally, they cannot sleep in like the rest of the family - in this case also, they have to get up earlier than anybody else because they have chores to do. There are instances also where domestic servants cannot eat when they are hungry because instructions to eat have to come from their employers.

One wonders, though, why they remain in servitude or accept reassignment if they consider their employers' treatment of them as enslavement. । found my answer in a simple response by Angela who had lost both parents, "we are after something," she said! The pursuit of that "something" (exposure to city life and common etiquette, skill training and reduction in the level of household dependency on their families) could go on unabated until they derive optimum satisfaction and utility (see Kevane, 2004) from their stay as domestic servants with other families.

Child domestic servitude and other forms of child labor existed prior to the on-set of neo-liberal economic policies in Ghana. While it is true that harsh 
economic realities facing Ghanaian families and women in particular as a result of unfavorable neo-liberal economic policies cause some children to end up in child domestic servitude and consequently contemporary slavery, I observed that for the participants in this research, unless the domestic servant is too young to decide for herself, what sustains this practice are their expectations of gains and rewards. These expectations also direct the processes of recruitment. They will continue to accept offers of recruitment in so far as they believe in the potentials of living with other families in the cities.

\section{CHAPTER SUMMARY AND CONCLUSION}

This dissertation adopted definitions in the literature about slavery in general and contemporary slavery in particular. Important among the attributes of contemporary slavery is the nature of exploitation, whether or not they are old enough to be able to consent to their employment, if they get paid at all, and if they can voluntarily leave servitude. The juxtaposition of the theories and experiences of domestic servants as discussed above lead to two major conclusions. In the first place, I conclude that many child domestic servants in Ghana are not contemporary slaves in absolute terms, but quasi-slaves. In the second place, I notice the cultural practicality of child domestic servitude, this being observable in the training that respondents claim they receive in housekeeping, etiquette and apprenticeship. 
Most of the participants in this research were old enough to accept job offers. They had attained the basic education and were at least 15 years old, which is the minimum age of employment in Ghana. Some girls voluntarily dropped out of school, without the influence of their parents or any adult, before becoming domestic servants. Such school dropouts in fact waited for the opportunity to become domestic servants in the cities. It is in regards to the fact that school dropouts in Ghana use domestic servitude as a means of acquiring their economic independence during adulthood that I conclude that this type of child labor is culturally practical, but only to the extent that the children would be provided the chance to acquire some type of trade.

My observation that this would help socialize the children and to keep them busy while they stay out of school, notwithstanding, I do agree with my respondents that although they are not acquired through slavery means, the way they are treated while living with their employers tends to be enslaving. That most of them are not paid substantiates this observation.

In answering the question on the beneficiary of their incomes, the data exonerate their parents or families from the assumption that they sell or give their children away into contemporary slavery in order that the families would survive. Contrary to Moore's exclusion of the exploitation of family labor from slavery, I would have defined these respondents as slaves if their families were usurping their incomes. As it turns out, the definition of these domestic servants as slaves is restricted to their in-service experiences. 


\section{CONCLUSIONS: HISTORICAL AND ECONOMIC EXPLANATIONS OFCONTEMPORARY CHILD DOMESTIC SERVITUDE}

Child domestic servitude exists in Ghana today primarily because there is a huge demand for it. This demand, according to the two theories of survival strategies that partially guided this research, exists because of worsening poor conditions in both rural and urban regions. Usually, child domestics originate from rural Ghana and live with households in urban or semi-urban communities. Contrary to newspaper reports and prior research about child labor in other parts of the world, children who work as domestic servants are neither sold nor obtained through trafficking. Instead, a majority of them voluntarily drop out of school and either look for potential employers or accept offers from recruiters who will help them migrate to the cities to work as domestic servants. This dissertation also discovered that contrary to my pre-research expectations, a large number of domestic servants in Ghana are older than the minimum working age, and that they often complete the basic education before entering domestic servitude. I concluded from the qualitative data that cotemporary child domestic servitude evolved from a historical practice of children living with newly married female members of their extended families in order to provide free domestic services and in exchange, receive training in some type of trade, housekeeping skills and in some cases, formal education. 


\section{REASONS FOR THE CONTINUED EXISTENCE OF CHILD DOMESTIC SERVITUDE IN GHANA}

As I argued in this dissertation, the $C R C$ requires that children remain in school until the minimum working age, and also that they be provided with some skills that will enable them become useful and independent members of society in adulthood. Like the CRC, the Convention for the Elimination of Worst Forms of Child Labor calls on party states to protect their children from harmful employment and those that would inhibit their successful socialization and physiological growth. Given the role of the Minimum Age Convention, the stipulations of all other conventions protecting children from labor exploitation should be successful. However, this has not been the case. This dissertation outlined some of the factors that have thwarted the effectiveness of these conventions.

I noted earlier in Chapter Two that flexibilities in the Minimum Age Convention invariably sanction the exploitation of children under certain circumstances while protecting them from others. I suggested that in view of the fact that the lack of educational resources and infrastructure can cause children to take longer than normal to complete the basic education, permitting low income countries to lower the minimum working age means the licensing of the children's exploitation. In addition, although international law requires party states to ensure that children develop into independent adults, their preparation 
for adult roles are costly, and poor countries are not always able to finance their education.

Child domestic servitude exists because of economic and cultural reasons. Indisputably, it is a form of survival strategy for both the sending family and that into which the domestic servant is hired. To the hiring family, the domestic servant is a means of cheap or free labor for petty trading and for household chores. The domestic servant's family, on the other hand, perceives domestic servitude not as a means of its own survival as the literature purports, but as a means of helping their younger female members to become independent and useful adults. Households in urban and semi-urban areas are those who usually hire domestic servants. Depending on the occupations of the heads of such households, the domestic servant would be engaged exclusively in petty trading or in household chores. More often than not, domestic servants, this research discovered, combine the two types of responsibilities.

I observed that whichever direction we analyze domestic servitude, these responsibilities corroborate the MML theory of survival strategy that urban households have had to rely on multiple sources of income following worsening poor conditions that resulted from unsuccessful neo-liberal economic policies. They either earn incomes through domestic servants' duties of selling for their employers, or through the savings that the households make by not hiring adult domestics while female heads undertake professional careers outside the home.

In semi-urban communities that have some social amenities and infrastructure such as high schools, hospitals, domestic servants usually sell 
cooked food, keep convenience stores of their employers and at times take care of household chores if the household does not have a second servant. In urban communities also, domestic servants combine household chores with petty trading for their employers. As I observed, the difference between semi-urban and urban employers lies in their respective levels of education and type of primary occupations. Self-employed petty traders, the data showed, are more likely to employ domestic servants for commercial activities. Employers with multiple sources of income also assign domestic workers to petty trading. In order for such households to enjoy the services of domestic servants in both their businesses and around the house, some employers choose to have more than one domestic servant. Afriyie's and Hawa's employers discussed in the preceding chapters are two examples.

For working 10 to 16 hours a day, the working conditions of Ghana's domestic servants may not be considered appalling if they receive remunerations commensurate with the amount of work done. Many domestic servants, as earlier discussions in this dissertation pointed out, do not get paid for the services that they provide. In order for them to get paid, domestic servants who participated in this study have to overstay the agreed period of two to three years. According to the data, those who receive payments without staying the entire duration usually are recruits of non-formal agents of recruitment. The cash payment or the training that those who get paid receive is usually not commensurate with the child domestics' work. The highest paid non-formally or informally recruited current domestic servant received C80,000 (approximately 
$\$ 7.00$ ) a month for working 10 to 16 hours a day. Others choose to pay their servants off at the end of their service. The usual means of payment is an enrollment in an apprenticeship, either to become a hairdresser or seamstress. At the time of recruitment, employers usually arrange with families, or the servants themselves, the method of payment and how much it should be. On average, employers agree to enroll them in the apprenticeship after two years of service. The entry fees ranged between $\mathrm{C} 200.000$ and 1 million. Employers must also get their recruits sewing machines and the necessary tools to start the training. Even when they provide these after the two year period of service in addition to the domestic servant's living expenses, they probably would not be justified for underpaying or not paying the servants.

The sending families also gain from their younger members' engagement in domestic servitude. However, this research concludes that such benefits are mostly non-fiscal. In the first place, the sending families do not have to take care of another dependent. In the second place, if successful, the domestic servant will return home financially ready to start learning a trade, an indication that the family will not have to struggle about the younger member's future economic security. On rare occasions, servants who receive cash for their services remit part of it to their families back home. In this research, only one respondent, Akosua, sent an equivalent of a month's wage to her mother, who was taking care of the former's son.

Domestic servants usually request either their employers or recruiters to save their incomes until the end of their service period when they collect 
everything for their training. The family's hope of seeing their younger member return home ready to learn a trade may be squashed if for any reason, the daughter decides to leave servitude prematurely. This research observed that servants at times left servitude before the contract period ends when they considered their employers' homes to be too quiet. There were other participants who left employers' homes because they had stayed too long and were not expecting their employers to pay them off soon enough. When servants leave under such circumstances, they mostly lose their accumulated incomes. Employers told me that even when they do not pay or enroll domestic servants into training, we cannot conclude that the servants are not paid at all. Their reason is that they take care of the servants' basic needs and medical expenses.

\section{BECOMING DOMESTIC SERVANTS}

I identified three different approaches of recruitment and classified them as formal; non-formal and informal recruiters respectively. Formal recruiters were registered employment agencies which specialize in the recruitment of domestic workers, house-boys, garden-boys and cooks. These employment agencies receive applications from both domestic servants and households looking for helpers. Informal recruiters are neither registered nor regular. They are the occasional intermediaries between prospective domestic servants and their employers. There were three different types of informal recruiting. The first type involves family members who assist relatives to either recruit or to become 
domestic servants. The second type involves non-family members, while the third is a combination of both family and non-family members.

Although different from the two other types of recruiters, non-formal agents exhibit traits of the formal and informal recruiters. They are regular recruiters who, although not formally established as agents of recruitment, bring children from rural areas to live with and work for other families. Like the informal processes of recruitment, they employ children of all ages, making these domestic servants vulnerable to various forms of abuses and exploitation. The non-formal recruiters receive no payment for their services, except for the reimbursement of their travel expenses when employers send them to the villages.

I observed a number of similarities and differences among Sophia and Derrick's recruitment patterns on one hand, and those of Ali and Ahmed on the other. Unlike Derrick and Sophia, Ali's and Ahmed's recruits lived in less developed towns with petty traders who did not need them to work only around the house, but to hawk and or keep small shops. Another difference is the educational and economic backgrounds of their employers. Whereas employers at Tikobo \#1 and Bonyere where Ali and Ahmed served, respectively, were primarily semi-educated low income earners who lived off petty trading, those at Accra and Cape Coast where Derrick and Sophia served were highly educated university professors and businessmen who had better economic standing and social class. 
The period of stay for Ali's and Ahmed's recruits ranged between two and three years. Three factors probably responsible for the low recruit turnover for Ali and Ahmed are the cultural backgrounds of their recruits and their similarities with their destinations. There is a general notion among Ghanaians that the northerner is most subservient of all the tribal groups in Ghana. They could tolerate those abuses and contempt characteristic of domestic servitude in general, which the girls from the south could not endure for long. The second factor is the similarities between the hometowns and Tikobo \# 1 and the surrounding villages. The northern part of Ghana is the least developed in the country and thus exhibited much of the rural attributes that characterized Tikobo \#1. Among these characteristics is the lack of individualism that domestic servants at Accra and Cape Coast encountered. Recruits to Accra usually complain of the quiet neighborhoods and curtailed their contracts as a result. The third factor is the lack of competitiveness in the rural areas.

I observed three different scenarios as far as relationships among recruiters, employers and domestic servants and their families were concerned. These are the non-familial relationship, the kin-group relationship and the shared-community relationship. The pattern of non-familial relationship exist where domestic servants worked for total strangers who come from and live in different parts of the country; and have someone look for a helper from the rural area for them. I categorized the relationship between a domestic servant and her employer as the kin group relationship if they are related by blood or through marriage. Extended family members fall under this category. Out of forty-four 
current domestic servants, seven lived with blood relations. One of them was a male. My pre-research expectation that domestic servants who lived with relatives would be least abused proved to be wrong for the respondents in this research.

The shared community relationship existed when domestic servants and their employers originate from the same village or hometown. There were about six respondents who came from the same hometowns as the female heads (i.e. the wives of the male heads) of the households that they lived in. I observed that this attitude of shared community creates some sense of commitment in female household heads who are directly responsible for the domestic servants. Even when highly dissatisfied with the domestic servant's performance, an employer who came from the same hometown as their servants were more willing to provide some type of remuneration than those from different hometowns.

\section{THEORETICAL IMPLICATIONS OF THIS DISSERTATION}

This dissertation sought to fill vacuums that existed in the literature on child domestic servants in Ghana prior to research. Before going to the field, there had not been any scholarly publication on child domestic servants in Ghana. As a result, this research was primarily exploratory. It aimed at discovering the recruitment processes, working conditions, procedures of exiting from servitude and methods of payment and disbursement of the servants' incomes. Sampling techniques that I employed in this dissertation sought to 
overcome the problems that according to the literature, characterized research on children who work within the household. The survey technique was not effective in identifying domestic servants because of the issue of mistaking them as the children of household heads.

As mentioned earlier, this dissertation confirmed observation in the literature that child labor in general exists because of poverty. However, it refutes the theory that some families' survival depends on incomes from their children's work. This dissertation discovered that families encourage their children to work because of the anticipation that it could be the only means through which children would become independent and useful adults in societies. I observed from the participants in this research that families usually have no access to incomes that their children generate from their domestic servitude.

Existing research on child domestic servitude illustrates relationships between gender and child domestic servitude. In some societies, girls are restricted to working within the household for security reasons. In other societies, girls are more likely to work as domestic servants because of the belief that it helps socialize them into gender related adult roles, specifically as housekeepers. According to my research, parents and families are not permissive of child domestic servitude because of security reasons. Additionally, I understood that it is rather expectations of gender related socialization on the part of both parents and the domestic servants themselves that drive parents to allow domestic servitude. As I indicated in Chapter Six, parents and children believe that the domestic servant stands a chance of being exposed to city life, general 
etiquette and training in decorum that they may not receive should they live in the villages their entire lives.

In fact domestic servitude emerged in Ghana because of the quest for children to receive adequate gender socialization. The Director of Ghana's Social Welfare, Mrs. Mary Amadu traced the history of domestic servitude in Ghana to the extended family's reliance on married female members to socialize younger members by training them in domestic chores, general comportment and in some cases provide them with formal education. An employer also told me mothers from her hometown usually sent their teenage girls to live with her so she would be able to provide them with housekeeping training and to help them become independent adults and good wives.

Closely related to gender socialization is the impact of lineage on child domestic servitude. This dissertation distinguished between two major types of lineage. These are matrilineal and patrilineal systems of inheritance and success respectively. Using the literature, this research traced domestic servitude to the role of women in both matrilineal and patrilineal ethnic groups in Ghana. It argued that contrary to assertions in the literature that patriarchy did not exist in many African countries until colonization, matrilineal and patrilineal structures thrust much more economic and political power in men than women.

Consequently, contemporary socialization in Ghana focuses on placing women in gender related roles. Therefore, when families are not able to finance their young females through junior secondary schools, looking for households that 
they can serve and be able to eventually learn trades and household chores seem to be plausible options.

As regards contemporary child slavery, this dissertation could not find any compelling evidence that helps to categorize all of Ghana's domestic servants either as absolute slaves or free labor. The literature does not define the contemporary slave as persons who are owned as commodities. Rather, it is the nature of exploitation of the victims' labor, the age at which they are employed, if they are able to consent to their employment or to voluntarily exit from it, and if they are paid at all. Processes of recruitment of the domestic servants who participated in this research were not enslaving. Kathleen Barry's (1984) convincing argument about the role of maturity and knowledgeability in children's ability to give consent to their employment led this dissertation to the conclusion that most of the domestic servants are not absolute slaves in the contemporary sense. In the first place, a majority of my respondents were old enough to give consent to their employment. Additionally, they had received the basic education and so I could not conclude that their rights of basic education had been violated. I could not define those who had dropped out of school as slaves either, because at the time of their employment, they were knowledgeable enough to even look for employers for themselves. They were not coerced into dropping out of school and into domestic servitude. Where the domestic servant could not voluntarily leave their employers' households, I observed that this was due to their parents' insistence on them remaining in domestic servitude until they received enough money to start learning trades. 
I could define two of the current domestic servants as child domestic slaves using the criteria above. They were too young to consent to their employment. I noted from the interviews that they would like to go back to their parents, but they did not have that freedom to do so. One of them, Selasie, did not know her parents or where she came from. The other young servant, Serena, knew her parents, but could not trace whey they live. These two girls were not given the chance to go to school. Besides long hours of unpaid services, they suffer all forms of abuses. Indisputably, Selasie and Serena are examples of contemporary slaves.

Although I could not categorize a majority of the respondents as contemporary slaves, the domestic servants, their parents, officials that I spoke to, the recruiters and some employers admitted that the treatment that most of them receive from their employers is enslaving. They work under exploitative conditions that are slavery-like. If the majority of my respondents could neither be categorized as contemporary slaves nor free labor, what can we identify them as?

On one hand, we observe that most of these young women or girls have obtained the compulsory basic education or are old enough to qualify for employment within the household. They freely offer themselves for employment and given their age and background, are at least knowledgeable, if not mature enough, to give informed consent about their recruitment. Some of them are able to learn trades and to become economically independent through domestic servitude. For these reasons, I have already pointed out that I could not 
categorize all of them as contemporary slaves. On the other hand, however, they work long hours, at times without pay, and as most of them asserted, are treated as slaves. Given the domestic servants' willingness to stay as long as it takes to get their dream of being enrolled in an apprenticeship, employers do not make good their part of the bargain by paying them off at the end of the agreed period. Based on these assertions, I could not discard their statuses as slaves, however trivializing critics of the discourse on contemporary slavery might consider it.

This dissertation defines Ghana's child domestic servitude as a form of labor-repressive system in which girls and young adults are exploited under slavery conditions. I differentiate them from the severely exploited and controlled contemporary slave by defining them as quasi-slaves. The level of exploitation that they suffer, and their own admittance as well as that of some of their parents, employers, the two government officials that I spoke to and their recruiters, could not be ignored. They are victims of labor-repressive systems as identified by Moore. To conclude, therefore, I have defined the quasi-slaves of Ghana's domestic servitude as persons who, although obtained through what might be described as acceptable means of recruitment, suffer verbal and physical abuses, stand a high probability of not being able to leave servitude for fear of losing their accrued incomes or for the lack of the freedom to do so, and who generally suffer forms of slavery-like exploitations and abuses. 


\section{TOWARDS THE ELIMINATION OF THE LABOR-REPRESSIVE SYSTEM OFCHILD DOMESTIC SERVITUDE IN GHANA: RECOMMENDATIONS}

Ghana has ratified the three most important conventions that have been enforced to protect children and to eliminate worst forms of child labor exploitation. These are the ILO Convention concerning the Minimum Age for Admission to Employment (C138), the UN Convention on the Rights of the Child and Convention on the Elimination of Worst Forms of Child Labor (C182). As the preceding chapters especially Chapter Two illustrate, Ghana has embarked on many activities to protect its women and children. Unfortunately, these have not been successful. In this last section of this dissertation, I make some suggestions and recommendations that could expedite action on the programs to eliminate child labor exploitation, or at least to help reduce its existence.

This dissertation earlier illustrated the correlation between formal school participation and the incidence of child domestic servitude. It concluded that children who drop out of school or are never enrolled are most vulnerable to labor exploitation. Therefore, the first major step to reducing or eliminating child labor exploitation is to encourage school participation and retention. I outline a number of ways to motivate the children to stay. The provision of meals to school children during breaks is the first important step. This will reduce dependency on parents and compel them to ensure that their children attend school regularly. I assume that the children will also find a reason to be there.

This would be costly to the government. An attempt on the part of the 
government to pass this cost onto parents would negate the very purpose of this plan - parents would prefer their children stayed at home.

This brings me to the second strategy to increasing participation in formal education in Ghana - the reduction in costs to the parents. So far, the FCUBE has not worked. Under the FCUBE project, basic education in Ghana is supposed to be free. Nevertheless, new charges such as furniture fees, building fund and Parent Teacher Association (PTA) dues in addition to costs of stationery and books make elementary education very expensive for rural and poor parents in general. Therefore, to ensure the success of the FCUBE, the Ghana Government must make good its promise of making basic education free and compulsory by adequately providing the needed resources. This gesture of official generosity is certainly indispensable towards the attainment of the main objective of the FCUBE. The need for individual school administrators to levy various charges to parents must inevitably be eliminated. It might become crucial to criminalize such means of obtaining money from the poor.

In addition, instead of leaving the burden of the training of domestic servants to employers and parents, a short term program of sponsoring such training could be instituted. This is the third strategy to solve the problem of child labor exploitation. This way, rural children will not consider domestic servitude as an indispensable approach through which they would become economically independent in their adult lives. The implementation of this short term program could also be adopted by domestic and international non-governmental 
organizations that have made the rights, welfare and education of children important parts of their goals.

The fourth strategy is in regards to the training programs. In the long term, the training of girls to become hairdressers or dressmakers could be integrated into the regular curricular of basic educational structures. I am aware that at the elementary school, children learn some basic sewing. Beyond the elementary, parents who can afford it send their children to vocational schools for these training. If the level of this training in basic schools is improved, it may not be so costly for graduates from junior secondary schools to further it at a higher level.

The above suggestions notwithstanding, I do not recommend an emphasis of the training of girls in hairdressing and dressmaking. This is in view of the anticipation that the market for hairdressers and dressmakers will be saturated soon given the rate at which graduates of Ghana's junior secondary schools enter this trade. Additionally, girls do not always have to be socialized into these low paying gender biased occupations. As a result, I suggest that rural girls be made aware of other occupational choices and be provided the opportunity to train in them. When they are knowledgeable of the many occupational training opportunities that exist in schooling, both parents and children would strive to utilize them. Where $60 \%$ of children coming out of the junior secondary schools in some rural communities do not acquire basic literacy and numeracy, both parents and children may lose sight of the significance of education if they are not persistently kept informed about schooling. 
The fifth suggestion focuses on the government's attitude towards international conventions. Ghana was the first to accede the CRC while more than half of those countries that first ratified it were Africans. However, it took ten years for 15 African countries to ratify the African Charter on the Rights and Welfare of the Child (ACRWC), which was adopted by the Organization of African Unity (OAU) in 1990 but came into force in 2000 (de Waal, 2002). Like Alex de Waal (2002), I wonder if signing international conventions are just a symbolic act and an approach to acquiring status within the international community, rather than a practical sign of commitment to solving the problems they attempt to address.

Given the above, the government of Ghana must see to the criminalization of the use of non-school going children in domestic servitude. Most importantly, stipulations in the many conventions that it has ratified must be implemented. This could be a hurdle for the government because many officials are guilty of using unpaid or underpaid domestic servants in their households. I therefore predict that it will take a well informed public or grassroots to fight this canker. Rural children have to know their rights. They must be educated on the CRC, the Children's Act of 1998 and the ACRWC. Abridged versions of these conventions and acts must be made in local languages so that parents will understand them and make them a part of their traditional socialization processes. While I do not suggest the riddance of the Ghanaian child's understanding and acceptance of the obedience and respect for every adult, I believe that their understanding of their rights would help them distinguish 
between fear and respect, and thus be able to renounce abusive adults and employers. Additionally, they would be able to hold officials accountable when they are well informed. This would bridge the gap between realities of the Ghanaian child's vulnerability and the stipulations these laws. As I argued earlier, children cannot go to court when they are abused. However, they can take advantage of WAJU and the Social Welfare should they understand the instruments protecting them.

Finally, the above suggestions will not materialize if corruption is not reduced. The Government of Ghana has to implement realistic strategies that would reduce corruption while increasing accountability especially among school administrators and government officials in general. If funding that could be put to use for the benefit of all is squandered by a few officials, the burden of educational funding on parents might remain high. Consequently, educational participation among the rural poor will continue to dwindle and child labor exploitation will remain on the ascendance. 


\section{List of References}

Adepoju, A. \& Oppong C. (1994). Gender, Work \& Population in sub-Saharan Africa. London: James Currey for International Labour Office.

Allman, J.; Geiger, S. and Musisi, N. (Eds.) (2002). Women in African Colonial Histories. Indiana: Indiana University Press.

Anderson, B. (2004). Migrant domestic workers and slavery. In The Political Economy of the New Slavery. Hampshire: Palgrave Macmillan Ltd.

Anker, C. (2003). The Political Economy of the New Slavery. Hampshire: Palgrave Macmillan Ltd.

Archer, L. J. (ed.). (1988). Slavery and Other Forms of Unfree Labor. New York: Routledge.

Argenti, N. (2002). Youth in Africa, a major resource for change. In Alex de Waal and Nicolas Argenti (Eds.) (2002). Young Africa: Realizing The Rights of Children and Youth. Trenton: Africa World Press, Inc.

Aryee, A. F., (1997). The African family and changing nuptiality patterns. In Aderanti Adepuji (ed) Family, Population and Development in Africa. London: Zed Press.

Bales, K. (2000). New Slavery. California: ABC-CLIO, Inc.

Bales, K. (1999). Disposable People: New Slavery in the Global Economy. California: University of California Press.

Banpasirichote, C. (2000). Rapid economic growth: the social exclusion of children in Thailand. In The Exploited Child, Schlemmer, B. (Ed.). New York: Zed Books.

Berlan, A. (2004). Child labour, education and child rights among cocoa producers in Ghana. In The Political Economy of the New Slavery. Hampshire: Palgrave Macmillan Ltd.

Bonnet, M. (2000). Introduction: child labour in the light of bonded labour. In The Exploited Child, Schlemmer, B. (Ed.). New York: Zed Books.

Barry, K. (1984). Female Sexual Slavery. New York: New York University Press. 
Bee, E. (1998). The Other Side of the Kitchen Door: Domestic Service in Lima, Peru. M.A. thesis, Department of Sociology and Anthropology, Florida International University, Miami.

Blagbrough, J \& Glynn, E. (1999). Child domestic workers: characteristics of the modern slave and approaches to ending such exploitation. Childhood, $\underline{6}(1)$.

Burra, N. (1995). Born to Work: Child Labour in India. Delhi: Oxford University Press.

Cabanes, R. (2000). Family versus the logic of the market. In The Exploited Child, Schlemmer, B. (ed). New York: Zed Books.

Cadet, Jean-Robert (1998). Restavec: from Haitian Slaver Child to Middle-Class American. Texas: University of Texas Press.

Child Labor Coalition (2005). Child labor in the US: an overview of child labor laws. <http://www.stopchildlabor.org/USchildlabor/fact1.htm> Downloaded January 10, 2005)

Child labor on the increase. (1996) African Business, 6.

Coquery-Vidrovitch, C. (1997). African Women: A Modern History. Colorado: Westview Press.

Cox, K. E. (1999). The inevitability of nimble fingers? Law, development, and child labor. Vanderbilt Journal of Transnational Law, 32 (1), 115(1).

Derby, C. N. (2003). Conceptual Framework for Understanding Contemporary Child Slavery. M.A. Thesis, Department of Sociology and Anthropology, Florida International University, Miami.

Donkor, N. T. (2001). Impact of Structural Adjustment Policies on Forests and Natural Resource Management. In Konadu-Agyemang, K. (2001). IMF and World Bank Sponsored Structural Adjustment Programs in Africa: Ghana's Experiences, 1983-1999. USA: Ashgate Publishing Limited.

Donkor, K. (1997). Structural Adjustment and Mass Poverty in Ghana. Aldershot: Ashgate Publishing Ltd.

Ellis, F. (1998). Household strategies and rural livelihood diversification. Journal of Development Studies, 35 (1), 1-38.

France, D. (2000). Slavery's new face. Newsweek, 118 (6255), 84-89. 
Fukui, L. (2000) Why is child labour tolerated? The case of Brazil. In The Exploited Child, Schlemmer, B. (Ed.). New York: Zed Books.

Gendreau, F. (2000) Public policy, society and child labour. In The Exploited Child, Schlemmer, B. (Ed.). New York: Zed Books.

The Ghanaian Chronicle. (2004). MPS Plead: Grace Coleman Deserves a Second Chance. <http://www.ghanaianchronicle.com/thestory.asp?ID=64>. (Downloaded August 20, 2004).

Ghanaweb.com (2002) Indictment of Grace Coleman.

http://www.ghanaweb.com/GhanaHomePage/NewsArchive/artikel.php?ID =41836. (Downloaded May 25, 2004).

Gladwin, C. (ed). (1991). Structural Adjustment and African Women. Florida: University of Florida Press.

Goheen, M. (1991). The ideology and political economy of gender: women and land in Nso, Cameroon. In Gladwin C. (Ed.). (1991). Structural Adjustment and African Women. Florida: University of Florida Press.

Guyer, J. I. (1984). Women in the economy: contemporary variations. In Hay, M J. and Stichter S. (eds). (1984). African Women South of the Sahara. New York:_Longman Inc.

Hawkins, S. (2002). "The Woman in Question": Marriage and Identity in the Colonial Courts of Northern Ghana, 1907-1954. In Allman, J.; Geiger, S. and Musisi, N. (Eds.) (2002). Women in African Colonial Histories. Indiana: Indiana University Press: 116-143.

Henn, J. K. (1984). Women in the rural economy: past, present, and past. In Hay, M J. and Stichter S. (eds). (1984). African Women South of the Sahara. New York: Longman Inc.

Hormeku, T. (1997). Ghana: the Numbers of the Last Five Years. <http://www.socwatch.org.uy/1997/ghana.htm> Downloaded August 21 2003)

Hondagneu-Sotelo, P. (2001). Domestica: Immigrant Workers Cleaning and Caring in the Shadows of Affluence. California: University of California Press.

Human Rights Watch Children's Right Project (1996). The Small Hands of Slavery: Bonded Child Labor in India. New York: Human rights Watch. 
Innocenti Research Center (Undated). Data Base on Child Labour in India: An Assessment with Respect to Nature of Data, Period and Uses. India: Thorat, $\mathrm{S}$.

Innocenti Research Center (2002). Child Work in Cote d'Ivoire. India: Francavilla, G., Lyon, S.

Innocenti Research Centre (1999). Child domestic work. Innocenti Digest, 5

ILO - International Programme on the Elimination of Child Labour (2002). Thailand - Child Domestic Workers: A Rapid Assessment. Geneva: Phlainoi, N.

International Labor Organization. (2001a). Stopping Forced Labor: Global Report under the Follow-up to the ILO Fundamental Principles and Rights at Work. Geneva: International Labor Office.

International Labor Organization. (2001b). Nepal Situation of Domestic Child Laborers in Kathmandu: A Rapid Assessment. Geneva: Sharma, S; Thakurathi, M; Sapkota, K.; Devkota, B.; and Rimal, B.

International Labor Organization (2002a). IPEC Action against Child Labor: Progress and Future Priorities. Geneva: International Labor Organization.

International Labor Organization. (2002b). Tanzania - Child Labour in the Informal Sector: A Rapid Assessment. Geneva: Kadonya C., Madihi M., Mtwana, S.

International Labor Organization and Inter-Parliamentary Union. (2002). Eliminating the Worst Forms of Child Labor: A Practical Guide to ILO Convention 182. Geneva: ILO.

Kasper, A. (1994). "A feminist, qualitative methodology: a study of women with breast cancer". Qualitative Sociology, 17(3), 263-281.

Kevane, M. (2004). Women and Development in Africa. Colorado: Lynne Rienner Publishers, Inc.

Kimaryo, M. and Pouwels, R. (1999). An African perspective: Child domestic workers in Tanzania. Child Workers in Asia 15(2), 26-28.

Konadu-Agyemang K. and Takyi, B. K. (2001) Structural Adjustment Programs and the Political Economy of Development and Underdevelopment in Ghana. In Konadu-Agyemang K. (2001). IMF and World Bank Sponsored 
Structural Adjustment Programs in Africa: Ghana's Experiences, 19831999. USA: Ashgate Publishing Limited.

Kopytoff, I. (1986). The cultural biography of things: commoditization as process. In Appadurai A (ed) (1986). The Social Life of Things: Commodities in Cultural Perspective. United Kingdom: Cambridge University Press.

Landsdown, G. (1994). Children's Rights. In Children's Childhoods Observed and Experienced, Mayall, B. (Ed.) (1994). London: The Falmer Press

Lange, M. (2000). The demand for labour within the household: child labour in Togo. In The Exploited Child, Schlemmer, B. (Ed.). New York: Zed Books.

Lukas E. (1996). Saving the Children. National Review, 48(24) 30-31.

Marguerat, Y. (2000). The exploitation of apprentices in Togo. In The Exploited Child, Schlemmer, B. (ed). New York: Zed Books.

Mbaye S. M. and Fall, S. A. (2000). The disintegrating social fabric: child labour and socialization in Senegal. In The Exploited Child, Schlemmer, B. (Ed.). New York: Zed Books.

Mbembe, A. (2001). On the Postcolony. California: University of California Press

Meert, H; Mistiaen, P.\& Kesteloot, C. (1997). The geography of survival: household strategies in urban setting. Tijdschrift Voor Economische en Sociale Geografie, 88, 169-181.

Meillassoux, C. (2000). The economy and child labour: an overview. In The Exploited Child, Schlemmer, B. (Ed.). New York: Zed Books.

Meltzer, M. (1980). All times, All Peoples: A World History of Slavery. New York: Harper \& Row, Publishers.

Mikell, G. (Ed.). (1997). African Feminism: the Politics of Survival in SubSaharan Africa. Pennsylvania: University of Pennsylvania Press.

Mishra, L. (2000). Child Labour in India. New York: Oxford University Press.

Mikay, E. (1997). An economic essential? The Middle East, 272, 38-40.

Moore, B. Jr. (1966). Social Origins of Dictatorship and Democracy: Lord and Peasant in the Making of the Modern World. Massachusetts: Beacon Press. 
Morice, A. (2000). Paternal domination: the typical relationship conditioning the exploitation of children. In The Exploited Child, Schlemmer, B. (Ed.). New York: Zed Books.

Martin, G. (2002). Africa in World Politics. New Jersey: Africa World Press.

Nukunya, G. K. (1992). Tradition and Change in Ghana: an Introduction to Sociology. Accra: Ghana Universities Press.

Obbo, C. (1980). African Women: Their Struggle for Economic Independence. London: Zed Press.

Oppong, C. (1974) Marriage among a Matrilineal Elite: a Family Study of Ghanaian Senior Civil Servants. London: Cambridge University Press.

Owusu, F. (2001). Urban Impoverishment and Multiple Modes of Livelihood in Ghana. Ph.D.Dissertation, Department of Community and Regional Planning, lowa State University, Ames.

Oyewumi, O. (1997). The Invention of Women: Making an African Sense of Western Gender Discourse. Minneapolis: University of Minnesota Press.

Palmie, S. (Ed.). (1995). Slave Cultures and the Cultures of Slavery. Knoxville: The University of Tennessee Press.

Patterson, O. (1982). Slavery and Social Death: a comparative study. Massachusettes: Harvard University Press.

Ramanathan, U. (2000). The public policy problem: child labour and the law in India. In The Exploited Child, Schlemmer, B. (Ed.). New York: Zed Books.

Ravololomanga, B. and Sclermer, B. (2000). "Unexploited" labour: social transition in Madagascar. In The Exploited Child, Schlemmer, B. (Ed.). New York: Zed Books.

Reh, M. and Ludwar-Ene, G. (Eds.). (1995). Gender Identity in Africa. Munster: Lit.

Robertson, C. C. (184). Women in the urban economy. In Hay, M J. and Stichter S. (eds). (1984). African Women South of the Sahara. New York: Longman Inc.

Robson, E. (1996). Working girls and boys: children's contributions to household survival in West Africa. Geography, 81 (4), 403(5). 
Romm, N. and Rwomire, A. (2001). Child abuse: the sociological perspective. In Rwomire, A. (ed). African women and Children. (2001). Connecticut: Praeger Publishers.

Rone, J. (1995). Children in Sudan: Slaves, street Children and Child Soldiers. New York: Human Rights Watch.

Sawyer, R. (1988). Childhood Enslaved. London: Routledge.

Schlemmer, B. (Ed.). (2000). The Exploited Child. New York: Zed Books.

Seabrook, J. (2000). Child workers, the shifting debate. Race and Class, 42(2), 80.

Shoishab. (1997). Child domestics in Dhaka, Bangladesh. Child Workers in Asia, $13(1), 4-6$

Slater, W. (1997). Are any domestic helpers employed in your household? Child Workers in Asia, 13(1), 26-27.

SLIMG Sri Lanka. (1997). Live-in servants in Sri Lanka. Child Workers in Asia, 13(1), 14-16.

Stark, O. (1991), The Migration of Labor. Cambridge: Basil Blackwell.

Stahl, A. and Cruz, M. D. (1998). Men and women in a market economy: gender and craft production in West Central Ghana, ca. 1775-1995. In Kent, S. (Ed.). (1998). Gender in African Prehistory. London: Altamira Press.

Stoeltje, B.J. (1995). Asante queenmothers: a study. In Reh, M. and LudwarEne, G. (Eds.). (1995). Gender Identity in Africa. Munster: Lit

Sunoo, B. P. (2000). Caution: children at work. Workforce, 79(9), 44.

Tashjian, V. B. and Allman, J. (2002). Marrying and Marrying on a Shifting Terrain: Reconfigurations of Power and Authority in Early Colonial Asante. In Allman, J.; Geiger, S. and Musisi, N. (Eds.) (2002). Women in African Colonial Histories. Indiana: Indiana University Press: 237-259

Tucker L. and Ganesan, A. (1997). The small hands of slavery: India's bonded child laborers and the World Bank. Multinational Monitor, 18(1-2), 17-19.

UNICEF. (1999). Child domestic work. The Innocenti Digest. Florence: International Child Development Center. 
UNICEF. (1998). Girls at work. New York: UNICEF.

United Nations Commission on Human Rights, (2002). The relationship between child domestic servitude and the sexual exploitation of children. $<$ http://www. antislavery.org/archive/submission/submission2002childlabour.htm>.

US Justice Department. (2004). Maryland Couple Sentenced for Forced Labor. http://www.usdoj.gov/usao/md/press releases/press04/BlackwellSent.pdf (Downloaded June, 2004)

Van Gennep, A. (1960). The Rites of Passage. Translated by Monika B. Vizedom and Gabrielle L. Caffee. Chicago: The University of Chicago Press.

Verlett, M. (2000). Growing up in Ghana: deregulation and the employment of children. In The Exploited Child, Schlemmer, B. (ed). New York: Zed Books.

Waal, A. de (2002). Realizing child rights in Africa children, young people and leadership. In Alex de Waal and Nicolas Argenti (Eds.) (2002). Young Africa: Realizing The Rights of Children and Youth. Trenton: Africa World Press, Inc.

White, L. (1984). Women in the changing African family. In Hay, M J. and Stichter S. (eds). (1984). African Women South of the Sahara. New York: Longman Inc.

The World Bank Group (2001) Upgrading of Low Income Settlements Country Assessment Report: Ghana. (Downloaded August 31, 10, 2003).

The World Bank Group. (2004). Ghana at a Glance. $<$ http://www.worldbank.org/data/countrydata/aag/gha aag.pdf $>$ Downloaded January 10, 2005). 


\section{APPENDIX}

\section{SAMPLE INTERVIEWS}

\section{Current Domestic Servants}

Int. 3

[After introduction and respondent's approval that I interview her]

I: who is the head of this household?

R3: I don't know

I: who is responsible for the upkeep of this family? How do you get food, for instance? Or who gives the money for your family to buy food?

R3: My mother [what she said literally translates that mother. She used this expression to refer to her 'employer'. ]

I: that your mother. What does she do to earn incomes?

R3: she gets money from the things that we sell.

I: How many people share your meals together? Like you are your own family, you cook, eat and share other resources together. [I still could not make myself understood so had to explain further]. This is a big compound with many different families. Each family has its own father, mother, children and may be other members, and together, they eat the same meals and share resources. Think about the one you belong to and tell me how many you are.

R3: seven.

I: seven good. How many of these work and bring home money?

R3: only [that] my mother.

I: ok, about how old is the oldest of the other members of the household? Is her husband a part of this household?

R3: he used to be a welder, but he lost that job.

I: good... can you tell me how much profit [that] your mother makes everyday?

R3: I don't usually note how much we sell, so I can't tell.

I: apart from [that] your mother and her husband who lost his job already, is there any other household member who works?

R3: no. 
I: where do you come from?

R3: I'm from Keta.

I: where is your real mother?

R3: she is in Tema

I: Tema, I would like to go there to talk to her. Is it okay with you for me to get the directions to go there?

R3: yes.

I: what does she [the biological mother] do for living?

R3: I think she sells foodstuffs like I am doing right now. She sells gari and stuff, but the market is not good where she is.

I: how many children does your real mother have?

R3: four

I: are you the oldest?

R3: inaudible

I: how many of you are females?

R3: two of us and two boys.

I: $\quad$ are all the boys in school?

R3: yes

I: do you go to school?

R3: I am supposed to be in school, but my mother said she could not pay the fees, so this woman promised to help me, but that I should live with her for sometime first. However, the time that she promised has already passed and I am still not in school.

I: the time has already passed... does your mother pay the fees of the other three children who live with her herself?

R3: yes.

I: so why didn't your mother bring one of your brothers but you?

R3: my brother is not old enough.

I: how old is he?

R3: 12 years

I: how old are you?

R3: 17 
1: is he the one who comes after you?

R3: yes

I: where is your father?

R3: he is in Keta.

I: $\quad$ and mother is in Tema ... are they no longer married?

R3: they are still married, but that's where he works.

I: what does he do?

R3: he sells things.

I: who did you live with when you were growing up?

R3: like what?

I: did anybody, apart from your mother, take care of you, say when she traveled out of town or went to the market?

R3: yes, when my mother first moved to Tema, I lived with one of my aunts.

I: what is the relationship between your mother and this aunt?

R3: [there is a loud cock crow that blurs the sound of the recorder] ... [she is silent for a few seconds]. I don't know, but I think she is my father's sister.

1: who else did you ever live with?

R3: inaudible.

I: $\quad$ cast your mind back to your early childhood again - who else lived in the same house or compound with you?

R3: inaudible - I lived with my cousin who is at Lapaz right now. I was still young.

I: about how old were you?

R3: I was like five years.

I: just a second. [another loud cockcrow]. Let us talk about your stay at lapaz, then we will return to this place. Were you enrolled in school when you lived there?

R3: Her boyfriend left, and thieves broke into the house, stealing all her things. She wasn't making a lot of money either, so my mother asked her to bring me to her.

I: did she send you to school though?

R3: yes. She got me started in school.

I: did you do any work for her? 
R3: yes, the place was a like a store, so I used to keep it and sell things for her.

I: so how old were you when you kept the store for her?

R3: I was five years

I: $\quad$ and you kept a shop. That was very good, congrats. So your mother removed you from Lapaz. Did you go back to school when you went to Tema?

R3: yes, I went to school for sometime, but because of financial problems, I had to stop and this woman said she would help me.

I: for how long have you been living with this woman?

R3: I will soon be two months.

I: is it two months or two years.

R3: two years.

I: and you haven't been enrolled in school yet...

R3: no, but I know she won't do that.

I: you know that...

R3: yes, because she doesn't do any other work except this, and she has to take care of all her children.

I: how many children does she have?

R3: four

I: what are their ages?

R3: the oldest is 23 .

I: and how is the youngest?

R3: the one after that is almost 19, then the one following is 17 . The last born is 12 .

1: what is the relationship between the woman you lived with at lapaz and your mother?

R3: they are family members.

I: family members...

R3: she wants me to come back to her, but since I came here, I am 'locked' [the exact word she used while speaking twi]. I would like to leave her and go there though. 
I: what makes you think you are locked here? Will she not allow you to leave should you decide to?

R3: she will let me go...but I can't tell her I want to go. I wish my mother will come for me when the time comes.

1: did anybody arrange for you to go live with the woman in Lapaz or your mother made that arrangement herself?

R3: someone arranged it.

I: but the woman you lived with is supposed to be your relative?

R3: yes

l: so who was this person that made the arrangement?

R3: I don't really know her.

I: who brought you to this woman?

R3: my mother.

I: your mother brought you herself...

R3: yes, but someone accompanied this woman when they came to us before we came.

l: then she promised to send you to school but hasn't done that. Does she pay you for the work you do?

R3: no she doesn't

I: $\quad$ she doesn't pay you... does she buy clothing for you?

R3: since she is a family member

I: is that so?

R3: yes, she is related to my mother.

I: how is she related to your mother?

R3: they are relatives, but I don't know how.

I: did she also promise that when you finish school, she was going to send you to an apprentice training?

R3: yes, she told my mother that she might buy a sewing machine for me after school if she has money. That's to enable me learn a trade, but I wish I could go back to school, to finish at least the JSS so that if I am not able to continue, then I could think about a trade.

[she starts sobbing] 
I: so why haven't you told her you want to go to school... did you tell her that?

R3: I always tell her that.

I: $\quad$ and what does she say in response?

R3: [still sobbing]... she tells me she will send me.

I: when do you usually wake up?

R3: five thirty.

Still sobbing so I had to stop to console her, to tell her it isn't too late yet, and that soon a door will open for her to return to school.

I: what time do you usually go to bed?

R3: around 9.

I: $\quad$ what do you usually do when you wake up?

R3: I sweep the compound, do the dishes, then I arrange the charcoal...

I: do you sell charcoal too?

R3: yes. One of her daughters is an apprentice at a hairdressing salon. If she gets up early, she might help me. Otherwise, I will do everything by myself

I: which one of her children is the hairdresser? The 21 year old?

R3: no, the 17 year old.

I: she is your age then?

R3: yes. I arrange the charcoal, put the rice [a big container of rice, not bagged, that is usually sold in cups] on the table, I mop here (the store). When I am done, I may take a shower, that's if the woman is here. She usually goes to the market to get more foodstuff for sale so if she is not back by the time I finish, I will have to be here in the store. Otherwise, in the night, I will take a bath before going to bed.

I: does that mean when you wake up in the morning, you clean, come to keep the shop and when you are done, you retire for bed?

R3: yes.

I: do they beat you?

R3: no, but they yell and insult me [crying now, I had to stop to talk to her again]

l: what are the insults? 
R3: the woman's husband is always insulting me... he just came to insult and left.

I: what do you do to him?

R3: you know he is not working, but he drinks a lot, so he comes here to take the money to go buy the drink. She asked him not to take her money again. When he comes around to meet her, he will insult her and if she doesn't mind him, he insults me too... [still crying], and my mother at times. You know when they came for me, there was no contract signed, so he says I am a gift [or slave?] to them that's why I behave the way I do.

I: you are a gift to them, he said so?

R3: yes

I: did he ever ask you to sleep with him?

R3: no

I: what else do they do that hurt you?

R3: if I do anything wrong, instead of just telling me to stop or not to do it again, they will just insult and yell at me.

I: which of them do that to you?

R3: the man and the woman (the husband and wife).

I: what about the children, do they insult and yell at you?

R3: [misunderstood the question] no, they like me.

I: are you able to do whatever you like in this house?

R3: like what?

I: are you able to decide for yourself what to eat, wear, when to go to bed or wake up... do they have to tell you the time to wake up or go to bed?

R3: I can decide when to go to bed or wake up, but I have to be up early enough to finish my work. So I always wake up at 5.30. When she (the woman) has to go to the market, she gets up at 3.30 and before leaving, she will help me by leaving the fish on the shelves and putting the prices on them for me [does she do that because she needs containers or what?]

I: $\quad$ can you decide what to eat or someone has to tell you?

R3: in the mornings, I usually prepare porridge for myself. I don't allow her [the woman] to do anything for me because when she does, she will talk about it all the time. When I first came here, I used to prepare the porridge for myself and so I continue to do that. If she is home, she may prepare tea and ask me to have some, or give me money to buy food, but 
I don't like that so at times, I could stay long without food, then I pray also so I use that to fast. I fast till 12 noon.

I: what about clothing, do they tell you what to wear?

R3: my clothing...

I: I just want to know if you can do whatever you want.

R3: no.

I: you are not able to do what you want. Who tells you what to do?

R3: at times the woman tells me what to do, how to go about things. Then there are times I take the initiative to clean, for instance.

[my informant tells me it is close to 10.30 , and that we have to leave before the woman meets us there. I was told she would return by 12 noon. She would not be pleased to find us talking to her maid, so we had to rush].

I: where do you sleep?

R3: we all sleep in one room

I: how many are you?

R3: we the women. I, the woman and her two daughters so there are four of us in general. The boys sleep with their father, so they are three.

I: do you sleep on a bed or on the floor?

R3: I sleep on a bed.

I: $\quad$ are you able to watch TV in this house?

R3: she comes to turn it off when I am watching.

I: $\quad$ are you able to use the living room like anybody else?

R3: when she is not around, yes.

I: $\quad$ are you able to watch TV when they are watching it?

R3: the TV is in our bedroom, so I sit on her daughter's bed. [why not on her bed?] that lady there is a friend of mine. They have TV so I sometimes watch it with them. I could also go to this other woman [points to a woman sitting in a wooden kiosk] to watch it too.

I: so you can watch it with them, but you can't turn it on yourself?

R3: yes. She will insult me.

I: do you use the plates, cups and utensils like anybody else?

R3: we've all been assigned our utensils. 
I: you said someone brought you to her. Did she pay your mum?

R3: no.

I: and they say your mum gave you to them as a gift.

R3: but that's what they say, my mother hasn't said that. They didn't sign any agreement that's why they say that.

I: are you able to communicate with your mother?

R3: yes.

I: how do you communicate with her?

R3: I call her...I tell her when anybody does something to hurt me. I usually don't report anything to the woman, unless she sees me so quiet, then she asks. In that case I will tell her.

I: what do you think will be their reaction should they find out that you call your mother?

R3: they won't do anything.

$\mathrm{I}$ have you visited your mother since you came here?

R3: no

I: has she visited you since you came to live here?

R3: she's been here once. She spent five days here. She has said that if her child lives with anybody, she will not go there to visit them.

I: is that so? You said the mother you live with is your real mother's relative?

R3: yes.

I: now, considering your experiences and conditions in this house, would you say that you are a slave?

She doesn't understand it, we try to explain it in Ga but she couldn't. when I explained using concepts like lack of freedom, abuse and exploitation, she said yes, she is a slave

We also asked for her mother's address and realized she doesn't know where the mother lives.

\section{Interview 4 -}

[After introduction and respondent's consent for me to interview her].

I: how many people live in this house?

R4: seven residents. 
1: how many of these work?

R4: aunt. Her husband and her sister used to work but they stopped.

I: what about the children?

R4: both of them are outside.

I: where are they?

R4: the girl is a student in the US. I don't know where the boy is.

I: what is she studying?

R4: I have no idea.

1: did she finish the university in Ghana?

R4: no, I was told she only finished the senior secondary school.

I: where did you live before this place?

R4: Saltpond.

I: really! I have been there before. Did you live there throughout your entire life?

R4: yes.

I: $\quad$ who did you say you lived with at Saltpond?

R4: I lived with my parents.

I: did you live in a compound house?

R4: yes

I: $\quad$ who lived there?

R4: my family and three people that were renting?

I: did your family own the home then?

R4: yes.

I: I would like to interview your mum later.

R4: I need to talk to her first but she doesn't have a phone.

I: if I get her name and address in Saltpond, I will be able to locate her.

R4: ok.

I: what's her name?

R4: Aunt....

I: $\quad$ what's her full name?

R4: it's my dad who is well known. 
I: and what's his name?

R4: Mr....

I: $\quad$ where does he work?

R4: electricity but he is on pension at the moment.

I: $\quad$ so will I be able to locate him by just mentioning Mr. Thompson?

R4: take a Cape Coast bound bus. After Mankessim, get down at Saltpond Junction. Get down at Afrengua junction, that's where you will find the mechanics. My brother works there and he is called ... or my sister's son, .... The two of them should be able to help you locate her.

I: $\quad$ what if I do not meet either of them?

R4: my brother was an apprentice at the shop. He finished the training and if you ask of him, they will be able to direct you to our home.

I: who usually took care of you in that compound home?

R4: my dad used to work outside Saltpond. He worked on electrification projects in so many villages.

l: $\quad$ were you raised by any other person apart from your parents?

R4: no please.

I: what about your grandparents?

R4: I spent some holidays with her when I was old.

I: how old?

R4: I can't remember, but I was in primary 5-6.

I: $\quad$ which grandparent was that?

R4: my mum's mother.

I: what about the other grandparents?

R4: my father's mum used to visit us when we were younger, but she was not as free with us as my maternal grandmother.

I: what about your mum's father?

R4: he died when I was young.

I: do you have any chore to do at the moment?

R4: no.

At 10.37, the phone rang. She answered and went in to call the other lady who returns to the living room to answer the call. 
I: what, in your opinion, causes children to live with other families although in your case you live with a relative?

R4: poverty or bad living standards. In some cases, it could be the 'employer' who might want to help the child if she has been to school before but the parents could not afford it.

I: $\quad$ so in your case, why did you move in with your aunt?

R4: when I finished school, my parents could not afford to further my education. So my mum told me my aunt wanted to help me, to put me into an apprenticeship.

I: okay, by the way what do you mean by aunt?

R4: she is my mum's sister.

I: how are they sisters?

R4: they are not real sisters. It's like this. My mum lived with my aunt's mother when she was young. So they are not related by blood.

I: I see, so how were you recruited? Did your aunt come looking for you to help or your mother made that request?

R4: my mother went to my aunt's mother to complain about her inability to further my education. So she, the other woman, suggested to my mother that I came here so they will put me into an apprenticeship to learn a trade.

I: $\quad$ which sort of trade?

R4: they asked me what I wanted...

I which is?

R4: seamstress.

I: have you started yet?

R4: no

I: $\quad$ when did you come to live here?

R4: $8^{\text {th }}$ September, 2001.

I: how many brothers and sisters do you have?

R4: we are five girls and one boy.

I: so that's the brother I am supposed to ask of, [name deleted]

R4: yes, [name deleted]

I: but [brother's name deleted] lived with your parents to learn his trade?

R4: yes. 
I: why was that, is it because you are a girl?

R4: (she smiles) no. My dad used to work at the time.

I: what's your birth position?

R4: I am the last born.

I: what do the others, apart from Papa Yaw, do?

R4: the first born is in London.

1: who sponsored her to go?

R4: my dad.

I: where is the second born?

R4: she is in Ghana.

I: $\quad$ what does she do?

R4: she started learning how to sew but didn't finish.

I: did she live with somebody?

R4: no she lived with my mother.

I: $\quad$ why didn't she finish her apprenticeship?

R4: $\quad$ she got pregnant and so stopped.

I: who financed her?

R4: my dad.

I: did all your sisters and brother finish the junior secondary school?

R4: no, at the time of the first born, it was the middle school. The second born finished JSS.

I: tell me about the third born.

R4: she is a seamstress and my dad took care of her financially.

$\mathrm{I}: \quad$ and the $4^{\text {th }}$ born?

R4: that's [name deleted].

I: the fifth born?

R4: she is a hairdresser. My dad supported her financially.

I: laughing - he must have ran out of money when he got to your turn then?

R4: smiles

I: $\quad$ you told me earlier you've been living here for two years.

R4: yes. 
I: $\quad$ earlier you said you lived with...

R4: I lived with my aunt's mother.

I: for how long?

R4: 1 year.

I: did she tell you and your mum that you would live with her instead of her daughter?

R4: no, she said I would be living with her daughter.

I: $\quad$ why did you live with her then?

R4: they said there was another girl here who was forcing to leave. I was promised that I would move to this place the very day she left.

I: what do you mean by "she was forcing"?

R4: she said she couldn't live here any longer.

I: $\quad$ why do you think she felt she couldn't live here any longer?

R4: I have no idea, but I think it was too much insults

I: only insults?

R4: the woman used to beat her, but she hasn't beaten me before.

I: how old was that girl?

R4: I don't know, but she could be old, looking at her. She couldn't be 20 years though.

I: looking at her...how? Did you see her picture?

R4: I met her the day I got here. I saw her picture too.

I: do you know for how long she lived here?

R4: l've been told she was here for two years.

l: $\quad$ did she learn a trade before leaving?

R4: no.

l: so you can't tell if she was also promised an apprenticeship?

R4: no, but the sister you see here has told me a lot about her.

I: has she said the other girl was promised an apprenticeship?

R4: no, she never told me.

I: who is that lady?

R4: she also came in to live with the woman (stops referring to her employer as aunt). 
I: did she go to school?

R4: no, she was not enrolled.

I: I would like to talk to her then. Could you please call her for me later?

Interlude with the older helper

I: $\quad$ was the other girl promised an apprenticeship?

$\mathrm{Rb}$ : the current arrangement is that when you live with someone's daughter, you have to let her learn a trade, or save the money to give to her after two years. But I am not sure the sort of arrangements made with the other girl.

I: $\quad$ who made that arrangement?

$\mathrm{Rb}$ : I heard it on a radio program, that that's what they do that.

I: $\quad$ so you are not sure if that's a real arrangement that is being practiced in the country today?

$\mathrm{Rb}$ : no, I am not sure.

I: which radio station did you listen to?

$\mathrm{Rb}$. I don't recall.

I: $\quad$ are you paid?

Rb: no, (she makes an exclamation remark and laughs loud).

I: I will talk to you in more detail later. How old are you?

$\mathrm{Rb}: \quad 32$ years (laughs again and agrees to talk to me.)

l: by the way, do you know how much they gave the other girl when she was leaving?

$\mathrm{Rb}$ : hmmmmm, about 500,000 (that's less than $\$ 100$ ).

I: $\quad$ is that a guess?

$\mathrm{Rb}$ : no, I am positive about it. It was not time yet for her to leave so it's like she didn't finish with her job - she wasn't really paid as a result.

I: I will talk to you later, probably not today.

$\mathrm{Rb}$ : ok.

Resumes actual interview (didn't take the time but talking to the older girl took about 6 mins).

I: You said they don't beat you...

R4: no, but they insult me. 
I: who insults you?

R4: the woman

I: is she the only one?

R4: yes, but when her husband sees anything, he doesn't talk about it and waits to complain to the woman when she gets back from work.

I: then what happens?

R4: she insults us.

I: what do you usually do to be insulted?

R4: for example, petty things that you don't consider so big an issue to warrant any insults.

I: like what?

R4: for instance, you've been asked to do something. While still on it, you are asked to do another thing. By the time you finish with the second, you may have forgotten about the first one. Then she will insult you.

I: what are some of the insults?

R4: she smiles, and appears reluctant to say anything. [Shakes her head to imply she doesn't recall any of the insults.]

I: it's okay if you can't say it.

R4: no, that's not so. I just don't remember. She is always yelling at us.

I: when do you wake up?

R4: $\quad 5.30$ a.m.

I: $\quad$ when do you go to bed?

R4: $9 p . m$., latest 9.30 .

I:' $\quad$ what do you do when you wake up?

R4: I open the windows, plug water to make tea for them...

I: who are those?

R4: the woman and her husband and her sister who lives behind in the outer house. I wash the car at times.

I: how often do you wash the car?

R4: Mondays, Wednesdays and Fridays. I wash it on Monday, I only dust it on Tuesdays, then dust again on Thursdays.

I: what else do you do? 
R4: when I finish attending to the woman till she leaves, I prepare her husband's meal.

$\mathrm{I}$ is it breakfast or lunch?

R4: breakfast.

I: where does she work?

R4: Tema Oil Refinery

I: what about the man?

R4: I hear he used to be a major. When he went on leave he started importing rice. That business collapsed and now I have $\mathrm{n}$ idea what e does.

I: $\quad$ where is he now?

R4: he went to town.

I: will he be here anytime soon?

R4: no, he usually gets home around $3-4$ p.m.

I: $\quad$ what do you do after that?

R4: I clean the living room, the toilets and bathrooms.

I: how often do you do these?

R4: everyday.

I: $\quad$ what time will it be by the time you finish with these?

R4: the man does not leave early, say around 9.30 a.m. If he steps out to make a call, I can clean the living room so I usually finish by $9.30-10$.

I: what if he doesn't leave early?

R4: then I finish around 10.

1: $\quad$ what do you do after that?

R4: I wash what the woman more the previous day.

I: then what else?

R4: I prepare dinner.

I: do you usually take breaks?

R4: yes, when I finish with everything.

I: $\quad$ and that's around 10 a.m.

R4: yes.

I: when do you start cooking? 
R4: the other woman prepares the stews or the sauces or soups on Saturdays. By a quarter to five p.m., I cook whatever will accompany the sauce.

I: $\quad$ are you paid?

R4: no

I: do you communicate with your family back in Saltpond?

R4: my mum sometimes meets her (referring to the woman) at Cape Coast so she usually extends her greetings to me.

I: does your mum visit?

R4: she has been here once since I came to live here.

I: $\quad$ when was that?

R4: somewhere last year.

$\mathrm{l}$ : is that all the contact you've made so far?

R4: my mum used to call here when I first came. But she stopped after the woman (she said 'she' - no longer refers to her even as the woman) started insulting me. I used to tell her about the insults and that made her sad. One of my sisters is married to a mason who is working on someone's home around here. The owner doesn't live here so my sister and her husband occupy the property as caretakers. I go there from time to time and I tell my problems to them. My mum communicates through them to me.

I: can you call your mum yourself?

R4: I don't have the number to call her.

I: you said earlier that when they started the insults and all..., what did you mean by the 'all'?

R4: when she doesn't go to work, you don't rest.

I: how often does she stay at home?

R4: she goes everyday except when she feels tired or sick.

I: $\quad$ tired... why tired? Isn't she supposed to work every work day?

R4: that's how it's supposed to be, but she goes at the time that she likes.

I: $\quad$ what about weekends and holidays?

R4: she works Saturdays and goes to church Sundays.

I: what's her position at work?

R4: she is a secretary. 
I: do you feel free to do whatever you like in this house?

R4: no

I: what does that mean... what can't you do?

R4: we can't go out. I have to be sent before I can step outside. But my dad didn't bring me up that way.

I: but I met you outside? Were you sent?

R4: yes,

I: who sent you?

R4: my sister (the other helper).

I: $\quad$ what else can't you do?

R4: I used to go to church, attend Bible studies and prayer meetings. I can't do any of those here.

I: can't you go with the woman to church.

R4: I can but she goes to a different church.

I: who decides what you eat, ear etc?

R4: I eat what they eat.

I: $\quad$ will you be permitted to go and visit your mum?

R4: I wanted to go and witness the Fetu Afahye of Cape Coast last year September. My mum called around the time and I told her about it. She suggested I spoke to the woman so I could travel to Cape for the festival. She also asked me to send her greetings to her (the woman). When I did and followed it with my intensions to go for the festival, she agreed but insisted that it was my mum that was forcing me to go and visit her.

$\mathrm{I}: \quad$ is she on good terms with your mum?

R4: smiles, yes.

I: $\quad$ so why hasn't she, your mum, talked to her about the insults?

R4: my mum is very soft. She would always say 'that's no problem' anytime you talked to her about such things.

I: do you think you are a slave?

R4: I sometimes feel I have no one, but when I visit my sister, she talks to me.

I: do you watch television?

R4: yes, with the other helper.

I: where do you sleep?

R4: in her daughter's room upstairs. 
I: $\quad$ you didn't answer my question on slave. Are you a slave?

R4: no

I: why?

R4: I don't have my peace and freedom in this house, but when I visit my sister, she understands my pain and worries, so she is usually able to comfort me.

I: what do you understand by 'slave'?

R4: someone who has nobody, lives with another person and so they can treat her anyway that they want.

l: $\quad$ but this definition fits the description you've given about yourself... what is the difference?

R4: because my parents are alive (starts weeping) so I keep wondering why they should treat me this way.

I: do you think children should live with other families?

R4: no

I: where does your madam come from?

R4: Cape Coast.

I: what about her husband?

R4: he is an Ashanti.

I: what about your dad?

R4: he is a Fante.

I: $\quad$ and your mum?

R4: also a Fante.

I: are you matrilineal or patrilineal?

R4: matrilineal

I: $\quad$ when do you think you will start the apprenticeship?

R4: they said January this year. But they had a funeral and so postponed it till after the funeral.

I: so what's the new date?

R4: they said last month. But when she got her salary, she said she needed to pay something else.

I: did she buy your sewing machine yet?

R4: yes. 
I: when was that?

R4: March this year.

I: $\quad$ would you like to leave this house now?

R4: there was a time I wanted to leave. I spoke to my sister about it and she said she would discuss it with my mum. My mum promised to call to talk tome but I never heard from her.

I: $\quad$ when did you want to leave?

R4: around April, last month.

I: which means you are willing to forfeit the training?

R4: yes.

I: how old are you?

R4: 18

I: $\quad$ when did you finish JSS

R4: 2000

\section{Int. 12}

[introduced the purpose of research and asked for her approval]

I: $\quad$ what is your ethnicity?

R12: I am a Kwahu

I; you are the first Kwahu that I am interviewing. How old are you?

R12: 18

I: Did you go to school?

R12: yes

I: what level did you get to?

R12: J.S.S. 3

I: did you finish?

R12: yes

I: how old were you when you finished?

R12: I was 15 when I finished

I: how old were you when you first lived with somebody?

R12: I was 17 years 
I: where did you live before going to live with this person?

R12: I lived in Kwahu when [name deleted] came for me.

I: from the Eastern Region?

R12: yes

I: what did he tell you when he came for you?

R12: he asked me if I would like to go and live in Accra. I said yes but asked him what I will be doing there. His response was that he would know what to do with me when we got there. His wife is my sister. He told my mother before bringing me.

$\mathrm{I}$ what did your mother say in response?

R12: he said to my mother that he was going to give me to somebody to live. And she gave him the go ahead.

I: could you have said no when your mother agreed?

R12: no

I: why not?

R12: she gave birth to me so I have to obey her when she asks me to do anything.

I: what would have done if it were your father that agreed that you go away?

R12: my father also agreed

I: what if your father had disagreed?

$\mathrm{R} 12$ : then my mother would have disagreed too

1: $\quad$ what if your mother had disagreed?

R12: the two of them would have discussed it or my mother would agree to what my father said

I: $\quad$ is it your father who has the final say?

R12: yes

I: who took care of you through schooling?

R12: both of my parents

I: what are their occupations?

R12: they are farmers

I: how many siblings do you have?

R12: they are five 
I: did they all go to school?

R12: yes

I: does any of them live with anybody?

R12: no

I: $\quad$ are you the only one among them who lived with another person?

R12: yes

I: how long did you live with the woman you just left?

R12: one year

I: $\quad$ did you stay for as you as you had to?

R12: I was there for only a year

I: how long did you intend staying there?

R12: he said I was going to live there for three years. After a year, however, there was a woman there who was maltreating me so I decided not to stay any longer.

I: he said three years, what was going to happen after the three years?

R12: the person I lived with was going to pay me off.

I: $\quad$ she would pay you off after three years, how?

R12: she would see me off by buying a sewing machine, a trunk or suitcase and fill with things

I: things like what?

R12: cloth, materials, dresses, and may be saucepans and aluminum pots

I: how did they estimate how many things to give you?

R12: they base it on your attitudes and your work

I: $\quad$ so after one year, what did they give you?

R12: she gave me money

I: how much?

R12: I don't know how much I was paid monthly, but she gave about three hundred thousand cedis to [name deleted]

I: he gave [name deleted] three hundred thousand to be given to you

R12: yes

I: $\quad$ how much did she say she would be paying you when you were going to live with her? 
R12: she didn't discuss that with me, she made that arrangement with [name deleted]

I: when you were leaving your hometown, did [name deleted] pay anything

R12: no

to your mother?

I: the woman never paid you when you were there?

R12: no

I: did she pay [name deleted]?

R12: yes, she paid his transportation costs

I: how much did she pay him?

R12: I think 80

I: $\quad 80,000$ reimbursement for his transportation, was that all?

R12: yes

I: $\quad$ why do children live with other families?

R12: if a child lives with one family and leaves them for any reason, and if there is another family looking for someone to live with, he will send the child there

I: ok, but why do children live with other families?

R12: ok, some people don't have anybody to take care of them. There are those who need a little income to go and a learn a trade; they want to learn a trade so when they get it, they leave.

I: $\quad$ you said there was a woman who maltreated you where you were living. What did she do to you?

R12: the woman herself didn't do anything to me but her auntie who lives in the house. When the woman [the person she lived with] got back from work, she went to report whatever you did to her.

I: that is her auntie?

R12: yes

I: $\quad$ what did she usually report?

R12: if you did anything wrong and she punished you, when she [the actual woman she lived with] came back, she told her

I: $\quad$ what were you doing wrong?

R12: like if she asked you to do something and you didn't, when the woman came she reported you 
I: $\quad$ why weren't you doing what she asked you to?

R12: not for any reason; you get tired for working a lot

I: what were you doing?

R12: we did the laundry, cleaned the rooms and scrubbed the bathrooms.

I: did you do these everyday?

R12: yes

I: from Mondays through Friday and on Saturdays?

R12: yes

I: ok, let's start from your mornings, what did you do when you first came up?

R12: when I wake up at 4, we sweep

I: who does that with you?

R12: nobody

I: ok

R12: when I finished sweeping, I iron their clothes

I: $\quad$ who are you referring to?

R12: when I am done with those, the sun will be rising so I will take my bath. The children will be up by now. I get them water to take their bath. After that we start packing the things to do wash. When we finish with the laundry

I: $\quad$ who do you do the laundry with?

R12: her aunt. I wash and she hangs them. When I finish, I do the dishes and then clean the rooms and mop. We cook after that and it will be around 3 p.m. by the time we finish. I will then iron the clothes and pack them.

I: $\quad$ are you done after packing?

R12: yes

I: so you rest after that?

R12: yes

I: $\quad$ when do you start doing all these?

R12: from Mondays [on week days] I don't rest till I am done

I: so you rest on Sundays after three?

R12: yes

I: what else do you do on Sundays in the evenings? 
R12: I don't do anything

I: don't you play at least?

R12: we watch TV

I: who do you watch the TV with?

R12: with her children

I: $\quad$ when do you wake up on Mondays?

R12: we wake up at four

I: $\quad$ with whom?

R12: alone, then I sweep, iron the woman's dress for work and put water in the bathroom for her to take her bath. I then prepare the children's breakfast and if they will go to school, I pack their books and put their bags in the car. When they leave, I start cleaning the kitchen, do the laundry and after that, clean the cups. I eat after that and then we clean the rooms and clean the windows or wash the nets.

I: who do you do these with?

R12: with the auntie, she helps me at times. When we are done with the nets, I mop the floor and it would be time for me to iron the things. It will be about five when I finish and the woman will be back. We will also have finished with the evening meals so we will serve her. She goes to her room when she is done and we will also have our meals

I: $\quad$ with whom?

R12: with the children. We do the dishes; there was a boy there who did the dishes with me after that. We would all have finished with out duties for the day, we watch TV after that and go to bed later.

I: what time would it be when you are finished?

R12: at times 8 or 7.30

I: $\quad$ so you wake up at 4 and work till 7.30 p.m.

R12: yes, I take breaks or take a nap

I: $\quad$ were you taking naps everyday?

R12: no

I: were you taking rests everyday?

R12: not everyday

I: how many times were you resting Monday through Friday?

R12: I was resting everyday, but in such a way that I will be able to do a lot of the things. 
I: who else lived in that house?

R12: they were whites

I: there were whites where you lived

R12: the woman's aunt is white

I: I don't understand... whose aunt was white, who were you living with?

R12: the woman who I lived with, her mother is Ga but her father is white. Her Aunt is also white. She also had a visitor who is white.

I: so how many people lived in that house?

R12: all of us?

I: yes

R12: [starts counting, murmuring to herself]

I: how many children does the woman have?

R12: three

I: how many aunts did she have there?

R12: only one, but she also had her daughter, the woman, her husband and husband's younger brother.

I: where does the woman work?

R12: at the airport

I: $\quad$ where did you live?

R12: I have forgotten the name of the place

I: $\quad$ was her husband a university lecturer [I asked this question because name deleted] had told me he recruits children for only the university professors]?

R12: no, her husband is a businessman

I: how old are their children?

R12: the first one is 11 , the second is 8 and the last is three years

I: were you able to do whatever you liked in that house?

R12: no

I: why?

R12: they didn't allow me to do what I liked

I: what didn't they allow you to do?

R12: like getting the chance to go out or to make friends outside. You can watch TV all you want, but not to go out to chat. 
I: so who was the head of the household?

R12: the woman because the man built the house for her

I: but that doesn't make her the head of the household. Who is more powerful?

R12: the woman

I: why?

R12: the man gave the house to her and she controls everything in that house

I: you said you are Kwahu, are you matrilineal or patrilineal?

R12: matrilineal

l: did you learn any trade before?

R12: no

I: you said the woman didn't maltreat you but her Aunt. What are you doing at [name deleted] house?

R12: I am helping his wife

I: $\quad$ are you waiting to be reassigned another household [I asked this question because that's what I heard even before I met her]?

R12: yes

I: has he told you he already has a place for you?

R12: no

I: when did you leave the other household?

R12: just this May [we were still in May]

I: when in May?

R12: last Saturday

I: how did you leave? Did you run away or you told them?

R12: I told them

I: did they ask you why you were leaving?

R12: yes, and I told them I had no particular reason

I: what did [name deleted] say?

R12: they called him and he came. He didn't say anything while they talked.

I: $\quad$ were you able to communicate with your mother while you lived with your parents?

R12: no 


\section{1: why not?}

R12: [tape didn't record this part]

I: why is it [name deleted] who has to take you?

R12: because he brought me

I: does that mean he has control over you and is responsible for you now?

R12: yes

I: when are you going to be in control of yourself?

R12: when I become old

I: you are 18, and we consider that as being old. When are you going to be old?

R12: when I finish learning a trade

I: what arrangements have you made with [name deleted] about your training?

R12: he will be going to my mother to discuss it with her

l: $\quad$ so your mother, [name deleted] and your father take the decisions about you. What did he say he will do with the money?

R12: he hasn't said it

I: $\quad$ will he give part of it to your mother?

R12: she giggles

I: is this too small to share?

R12: I want to save this, I will give her another time

I: did you ever remit her any money when you serving in that family?

R12: yes

I: where did you get the money from?

R12: [name deleted] remitted her

I: where did he get it from?

R12: I don't know

I: does the woman pay [name deleted][name?

R12: no

I: where did he get the money from?

R12: from the woman 
I: how do you know that?

R12: the woman gave it to him

I: did you see it when she gave it to him?

R12: yes, I was sitting there with them

l: $\quad$ why did she give it to him?

R12: [name deleted] said my mother extended her regards to me. She asked if he went to my mother and he said yes. Then she said that when he was leaving she would give him something to be given to my mother.

I: so [name deleted] didn't ask?

R12: no

I: where do you say that the woman come from?

R12: she is a Ga

I: $\quad$ what do you mean when you say her relatives are white [broni], are they light skin

R12: her father is white

I: where is her father from?

R12: London

l: $\quad$ and not Lebanon?

R12: I can't tell

I: $\quad$ would you have wanted to live with somebody if you were not a woman?

R12: yes

I: you said that her husband had a nephew in the household. What does he do in the house?

R12: he goes to school

I: he goes to school. Does he perform some of the chores that you do?

R12: yes

I: $\quad$ is it appropriate for children to live with other families?

R12: it's appropriate

I: why is it appropriate?

R12: some children need help. Some people need to live with people who will give them food. There are those who need money to supplement what they have so they can learn a trade.

I: $\quad$ are the children who live with other families slaves? 
R12: no

I: who is a slave?

R12: a laborer, like a servant

1: but those who live with others are not slaves.

R12: [laughs] they are since they also serve, but we've referred to them as housegirls so... [she doesn't understand housegirl]

I: $\quad$ what is the meaning of a housegirl?

R12: someone who has been brought to work (pauses) around the house.

I: $\quad$ what did they do to you that you didn't like?

R12: the woman [the auntie] used to yell at me

I: did they beat you?

R12: no

I: did the man ever attempt to sleep with you?

R12: no

I: nobody touched you in an immoral way?

R12: no

I: did you ever report the maltreatment to [name deleted?

R12: no

I: $\quad$ you just decided to leave.

R12: yes

$\mathrm{I}$ were you allowed to use the same cups as the other household members?

R12: yes

I: you were not assigned your own utensils?

R12: no, only the madam had her own cup

$\mathrm{I} \quad$ where were you sleeping?

R12: in the quarters

I: $\quad$ whom did you share the quarters with?

R12: nobody

I: did you sleep on a bed?

R12: yes

I: who bought clothes for you?

R12: the woman bought them for me 
I: were you sitting in the same chairs as the other family members when you watched the TV with them?

R12: no, all the children sat on the floor

I: with her children?

R12: yes, they either sat on the floor with us or sat in the bed

I: $\quad$ where is the TV?

$\mathrm{R} 12$ : in the auntie's room

I: did they train you when you went to live there?

R12: no

I: they didn't tell you what and how to do things?

R12: that they did. The woman told [name deleted] she needed somebody, but it was her husband who came for me. The next morning after my arrival, the woman told me I would be working in that house. She said I would sweep the entire house when I woke in the mornings, clean the kitchen, take the cups outside to wash them, do the laundry and that the auntie in the house would show me the rest of the responsibilities when I finished with the laundry.

I: thanks very much, those are all the questions I have for you.

\section{Former Domestic Servants}

[After introduction and her consent to participate in this research].

$\mathrm{I}$ : how many people have you lived with?

R51: About five

I: you lived with five people. How old are you?

R51: I am 18

I: how old were you when you first lived with somebody?

R51: I was... I first lived with my grandmother until her death. I was about nine years. Then I went to live with my mother's sister at Accra.

I: your mother's sister. Is she from the same mother as your mother or they are just relatives?

R51: they are real sisters. She is the youngest of my mother's siblings.

I: what is her occupation?

R51: she wasn't working. Her husband was in the military. 
I: why did you go to live with them?

R51: I was serving them when my mother sent a message that they should send me to school, or bring me back to her

I: did they send you to school?

R51: no

I: $\quad$ and you were nine at the time. What were the ages of her children?

R51: one of them was about 12 years and the second was nine

l: did the woman you lived with come to ask for you from your mother or your mother asked her to come for you?

R51: I was living with my mother's older sister at Kumasi. I wasn't going to school there. My mother wasn't here so a report was made to my mother at Accra who came for me.

I: how many years did you stay there before your mother asked them to bring you back to her if they wouldn't send you to school?

R51: I spent about two years

I: $\quad$ that long before she realized you weren't going to school

R51: yes, she gave a message to my uncles when they were visiting us at Accra that if they found out that I wasn't going to school, they should bring me back to her. My mother at Accra then decided to send me to school

l: $\quad$ what class were you when you started?

R51: I went to class two

I: did you go to the same school that her children went to?

R51: no. Her husband wanted to send me to a preparatory or international school but a man who was sitting there at the time suggested he sent me to just any school. So he registered me in some school. He wasn't buying books for me, a certain madam was buying the books for me

I: how is that man who advised him not to send you to the preparatory school related to him?

R51: they are not related, he was also in the military.

I: $\quad$ what reason did he give for such an advice?

R51: I don't know what it was

I: $\quad$ why did you leave their place?

R51: she just told me she couldn't live with me anymore and sent me to my mother. 
I: how long did you spend with them?

R51: I was thirteen

I: does it mean that you stayed with them for four years?

R51: yes

I: what were your responsibilities in that house?

R51: when I woke up in the mornings, I swept the yard, mopped the verandah, mop the kitchen, sweep the sitting room, arrange the chairs, scrub the bathrooms and then leave for school.

I: $\quad$ what time did school start?

R51: we started classes at 8

I: she asked you to leave. Did they beat you?

R51: the madam understood my conditions and so never beat me whenever I went late [referring to her lateness to school]

I: did they beat you at home?

R51: my mother wasn't fond of beating, but if she did, she could give you marks

I: did she insult you?

R51: yes

I: did they have other children living with them?

R51: no

I: you were the only child who lived with them?

R51: yes

I: $\quad$ and their children.

R51: yes

I: did you offend them in any way before they asked you to go away?

R51: no, I did nothing

I: did they get another person to live with them?

R51: I don't know what they did that after I left

I: $\quad$ where did you go from there?

R51: I went to my mother at Afram Plains

I: and what happened? 
R51: she sent me to an international school. Later, a message was sent to her that a relative was seriously ill. She left to see this woman and never returned. She therefore asked me to return to this place.

I: you never went back.

R51: when I came back, she sent me to another woman, she is dead now. She used to make soap [the atsotsoboa type I don't know what that is] for sale. It was a lot of work, so I told her I couldn't live with her anymore. Her farms were too far away, I had to go all by myself to bring food. So I decided to leave and I came back here.

1: $\quad$ where did she live?

R51: at Tepa

I: tell me in more details, what you did for her.

R51: I went to the farms, which were like five miles away. I would go there for cassava and plantain. On my return, I put them on fire and pounded the fufu. When I was done, I did the dishes before tidying up the rooms. I swept my room, she and her husband's room and the sitting room.

I: didn't you go to school when you lived with them?

R51: no

I: how many years did you spend at Afram Plains?

R51: I spent only a year

l: $\quad$ so you went to school for only a year and on your return, your mother sent you to the woman at Tepa. Did your mother say what you were going to live with her for?

R51: she wanted me to go to school there.

I: $\quad$ what did the woman say about your schooling?

R51: she didn't say anything about my schooling

I: $\quad$ what did she do?

R51: she sold second hand clothing and made the atsotsoboa soap

I: did you help her to make the soap?

R51: yes

I: did you sell them also?

R51: we used to send them to a nearby village called Hwidiem for sale.

I: who came with you?

R51: the woman 
I: were there children in her household?

R51: no, they went to school [as in boarding school].

I: so you were the only child there.

R51: yes

I: how many years did you spend with her?

R51: one year

I: and she never discussed your schooling throughout the year.

R51: no, and I told her I wanted to go away

I: $\quad$ what did she give you when you were leaving?

R51: nothing

I: did the other family 'see you off' when you were leaving?

R51: my mother you mean?

I: yes, the woman at Accra

R51: nothing, she didn't give me anything

I: from Tepa, where else did you go to?

R51: I came to my mother

I: what happened when you came to your mother?

R51: I went back to school, but I wanted to learn a trade instead so I dropped out. She withdrew me from the school and sent me to one of her sisters at Kumasi so she could enroll me in the apprenticeship. She later said she was moving so she couldn't live with me anymore.

I: how many years did you stay with her?

R51: about two and half years

I: did you start the skill training during those two and half years?

R51: yes, she didn't allow me to go everyday.

I: $\quad$ why didn't she allow you to go everyday?

R51: her own children were apprentices too, but she didn't have any significant source of income. She used to do laundry for people and when she went for the things to wash, I was the only person who helped her to wash them.

I: was laundry the only thing you did at home?

R51: when we got back, I cooked also and when it was our turn to sweep, I did that and cleaned the bathrooms. 
I: did she have children in the house?

R51: yes, one of her children was about my age

I: $\quad$ what did she do?

R51: nothing, she slept, by the time she got up, I would have finished with doing everything

I: when were you waking up when you lived at Accra?

R51: I went to bed around 1

I: $\quad$ when did you wake up?

R51: around 3

I: $\quad$ was it everyday or once in a while?

R51: her husband wasn't coming home early from town. He didn't like prepared meat from the market so he bought his own wild meat. We would have to prepare it when he got home and by the time we finished, everybody would have gone to bed in our block. When we are done, I did the dishes and so many other chores and when I finished, everybody would have gone to bed. Then I woke up around 3 to do chores.

l: did you do chores throughout the day?

R51: yes

I: $\quad$ when were you waking up when you went to Tepa?

R51: I woke up around 5 o'clock

I: $\quad$ when did you go to bed?

R51: around 10 o'clock. I woke up around 5 so by the time the sun was up, I would have finished with my chores

I: when did you wake up at Kumasi?

R51: I woke up at 5.30 to do my chores. If it was our turn to sweep, however, I woke up at 2. By the time the day broke, I would have finished with my chores

I: $\quad$ what changes occurred in your life throughout your stays with other families?

R51: if I had lived with my mother, I probably wouldn't be respectful; it is possible I wouldn't know how to do anything. I am not lazy doing anything, having lived with other people

I: why do parents allow children to live with other families?

R51: I can't really tell. Some people are poor and can't take care of their children and so they allow one of their children to live with other families 
I: what is your birth position among your mother's children?

R51: I am the fourth

l: where is the one after you?

R51: s/he is at home

I: $\quad$ where are the three older ones?

R51: one of them lives at Kwame Danso

I: what does he do there?

R51: that's where he lives

I: $\quad$ with whom?

R51: he is on his own

I: did he ever live with anybody?

R51: yes, he lived with the mother I lived with in Accra, at the Sojaline [that's the military barracks] in Kumasi.

I: $\quad$ why did he leave?

R51: I can't tell.

I: $\quad$ where is the third?

R51: he is Acheampong, he is here

I: did they go to school?

R51: yes

I: all of them?

R51: yes

I: $\quad$ were you paid when you left Kumasi?

R51: no

I: where are you from?

R51: I came from Kwame Danso

I: is that where you come from or you are from here?

R51: we are from here.

I: in your opinion, are children who live with other families slaves?

R51: they are not slaves to me

I: ok, they are not to you, but generally, are they considered slaves?

R51: the people they live with consider them slaves. 
I: who is a slave?

R51: they are those who are treated as though they were bought and so could be handled any how. They behave as if they bought them, and so they do anything they want with them

I: what is your mother's occupation?

R51: she used to sell yams on a wholesale

I: what about your father?

R51: he is a pastor

I: pastor of what church?

R51: I was very young when I left our hometown

I: does that mean you don't know him?

R51: yes

$\mathrm{I} \quad$ is he still married to your mother?

R51: no

\section{Interview 1}

[I describe the research to respondent and seek her consent].

I.: How would describe the eating arrangement in your house?

R1: We cook ourselves.

1: Who is the 'we'?

R1: I am the one who cook.

I: Who eat the food you cook?

R1: my mother, my father and everybody else.

I: Would you please tell me who everybody is?

R1: they are my grandparents and my siblings.

I: is it your maternal or paternal grandparents?

R1: it is my father's mother. My father's father passed away.

I: who, in your household, brings money home?

R1: my mother and my father

I: What do they do?

R1: They are farmers. They sell part of their farm produce to take care of the children. 
I: approximately how much money do they make in a week?

R1: a maximum of $\mathrm{C} 20,000$. There are weeks that they make nothing at all.

I: Apart from your parents, does any member of your household work to bring food or money?

R1: nobody else?

I: How old were you when you left for Accra?

R1: 12.

I: With whom did you live?

R1: I lived with my aunt's daughter. My aunt comes from same father as my dad's.

I: Before Accra, did you ever live with anybody else?

R1: none.

l: $\quad$ when you were growing up, who were the people that spent time with you within the household?

R1: We lived in my paternal grandmother's house. It is a compound home housing different households from the same extended family. My great grandmother, from my father's side, used to baby-sit me. When my mother went to the farm or to the market, her mother or sisters also took care of me. We lived in my father's house so I would spend the day with her family. She came for me whenever she got back home.

l: you have been living in your paternal grandmother's home since you were a kid. Can you call your maternal grandparents' home too yours?

R1: yes

I: why?

R1: that's because she is my mum's mother.

I: Who decided that you go and live in Accra?

R1: my father.

I: $\quad$ what did your mother say about it?

R1: she only agreed with my fathers decision.

I: $\quad$ what made your father decide that you go and live with his sister's daughter?

R1: I was named after her, that's my father's sister. My aunt came to request that I move in to live with her. But when I got to Accra, I lived with my aunt for just a week and then was sent to her daughter, my cousin also in 
Accra. My cousin is a bread baker, so I believe she needed me to come and help with the kneading under some sort of apprenticeship.

I: Were you in school before you left for Accra?

R1: yes, and I continued in Accra, except that I was not sent to any good school.

I: Why do you think your school was not a good one?

R1: they did not send me to the school I was supposed to attend.

I: why?

R1: when my aunt came for me, she was supposed to send me to an international school because the school I was attending was not a good one. Instead, she sent me to a "cyto" (a public school).

I: $\quad$ why was she supposed to enroll you in a private school?

R1: she promised to send me to a private school. My aunt assured us that I would even be repeated in my class at the time, just to enable me catch up. But instead of repeating me in my class, I was sent to a higher class.

I: $\quad$ which grade were you when you moved to Accra?

R1: I was still in class six.

1: and which class were you enrolled in at Accra?

R1: form one (the $7^{\text {th }}$ grade).

I: $\quad$ which means that you were enrolled in the right class - from class six you go to form one.

R1: no, I still should have been in class six because the academic year had not ended. And when it ended also, they should have repeated me. But this she did not do because she wanted me to finish school early to help with the bakery. "that was very mean on their part".

I: You stated earlier that you helped to knead the bread dough in the bakery. How did you do that, was it manually or with machine?

R1: both

I: which of the two methods was dominant? Manually kneading the dough or with machine?

R1: manual was dominant.

I: How much flour did you make in a day, on average?

R1: we usually made about 24 bags of flour in a day. 
I: thanks very much. I am at the moment going to ask about your other chores. When did you usually go to bed?

R1: between 10.30 p.m. and 11 p.m.

l: and what time did you usually wake up?

R1: around 4 a.m.

l: $\quad$ did you go to bed and wake up at these times everyday, Mondays through Fridays?

R1: yes

I: even on holidays

R1: yes.

I: $\quad$ what were your responsibilities?

R1: my first chore was to prepare breakfast for the children. Next I cleaned the bathrooms and did the laundry with my hands.

I: how often did you do these?

R1: everyday

I: how many bathrooms were you cleaning everyday?

R1: two bathrooms and two toilets.

I: $\quad$ whose clothing did you wash?

R1: My aunt's daughter's, her children's and her husband's.

I: how many children did they have?

R1: two

I: how old were they?

R1: they were aged 10 and 5 years at the time that I was leaving. When I first moved in with them, they only had one child who was one year at the time.

I: how long did you live with them?

R1: almost nine years.

I: did you say that you did laundry everyday?

R1: a lot. Clothing for four people.

I: but if you washed every morning, I presumed there weren't that many clothes for you to wash in a day.

R1: no, the children were, you know in the cities, the children change clothing very often. 
I: $\quad$ what was your typical day like, as far as your chores and responsibilities were concerned?

R1: when I wake up on a school day, I prepare the children for school. I bathed them and made their breakfast.

I: was it you who took them to school?

R1: no, her husband took them in his car.

I: You were in school yourself. At what time did you leave usually leave for school?

R1: around 7.30 in the morning, but I was usually late. I needed to be in school at 6.30 in order to be there in time, but I always got there at 8 when they may have even started classes.

I: $\quad$ what did you usually do after school?

R1: I had to return home to cook lunch and dinner.

I: $\quad$ when did you close and at what time did you get home?

R1: we closed at 1p.m. and I got home around 1:30.

I: How did you go to school?

R1: I walked to and from school.

I: is that all you did after school?

R1: no, I bathed the children and did the dishes. I also fetched water for the lady and her husband's bathroom.

I: what for?

R1: they used it the evening and the next morning. We didn't have running water in our home. My cousin's husband built a home later at Ofankor. There we had running water. But I left soon after we moved to that house...I forgot to mention this. The clothing I washed included her underwear too and those of her husband's.

I: $\quad$ what did you think about washing their underwear?

R1: it was painful, but if you did complain, she hit you.

I: $\quad$ with what?

R1: at times she used metal soup ladles. I even developed ear problems.

I: Ear problems, how were they like?

R1: my ear swelled from time to time.

I: what did the lady do at home? 
R1: nothing. She never went near fire, I had to do everything and then to serve them all.

I: about the bakery. When did you work there?

R1: the bakery opened in the mornings but I had to finish with my house chores before going to help with the kneading.

I: at what time did you leave for school then?

R1: no, I was not working at the bakery when I was still in school. But I worked there when school was on recess and over the weekends and on holidays.

I: $\quad$ what did you intend doing after the junior secondary school?

R1: I wanted to work as an apprentice in a hairdressing salon. I told them that but they refused and made me bake for them instead.

l: $\quad$ when you first came to live with them, what did they tell you you would be doing after school?

R1: well I didn't pass the exam. So I told them what I wanted to do. But they told me they won't because if I succeeded, I would take care of my parents and not them.

I: $\quad$ were you paid for the work you did?

R1: no.

I: did you ever take a break from your work at home?

R1: no

I: on holidays when school was not in section, when did you take breaks from household chores?

R1: I never had any breaks... may be around 10.30 p.m. when I may have finished with the chores. But by then I will be too tired and so will just go to bed.

I Did you watch TV at all?

R1: not regularly

I: Did you eat different food from anybody else?

R1: no, we all ate the same food.

I: how many bedrooms did you have in that house?

R1: it was a chamber and a hall. My cousin, her husband and the children slept in the chamber while I lived in the hall. I slept in the sofa which is not convertible. 
I: $\quad$ were you abused in any way?

R1: what do you mean?

I: were you beaten while you lived with them?

R1: yes

I: $\quad$ why were you beaten?

R1: Every little mistake I made provoked her so much she slapped my face often.

I: $\quad$ what was her husband's reaction when she beat you?

R1: he usually was not available. And when he found out I was beaten, he usually asked me to be patient with her, just so she would not beat me again. But she never changed.

l: did your parents benefit from your stay with them?

R1: no

l: $\quad$ were they offered anything, cash or kind when you were leaving for Accra?

R1: no

I: Did they abuse you in any other way?

R1: like what?

I: did your cousin's husband sexually abuse you or ever attempt to do so?

R1: no

I: did they insult you?

R1: yes, my cousin especially. Her husband also insulted me, but his was not as bad as hers.

l: what about the children?

R1: no, they never insulted me.

I: $\quad$ were you able to communicate with your parents while you were in Accra?

R1: yes, my dad used to call but while we talked, my cousin's husband usually came to sit close by so I could not talk much.

I: were you happy living there?

R1: no, I wasn't. But I could not leave because my parents did not have anything.

I: Do you wish you were still living there?

R1: no, I don't want to live with them anymore. 
I: So why didn't you leave their place?

R1: I couldn't because I went to live with them when I was very young. I was kept indoors and so I didn't know where to go if I decided to run away.

I: but you went to and from school all by yourself. Why didn't you run away?

R1: they were not as bad to me as they became when I finished school.

l: $\quad$ were you satisfied then with the way they treated you while you were still in school?

R1: yes and no. It's like this, if you live with someone, they tend to dislike you as you grow. When I became old, I relaxed my hair and she was annoyed for me to have not told her before.

l: how old is old, I mean when you said you were old, what age were you referring to?

R1: between 19 and 20 .

I: how old are you now?

R1: $\quad 23$

I: $\quad$ where did you get the money to relax your hair?

R1: her mum, that's my dad's sister gave it to me and asked me to do my hair with it.

I: $\quad$ why didn't you do your hair before age 19-20?

R1: I used to cut it.

I: why?

R1: because I didn't have the money.

I: could you have done your hair at say age $12 / 13$ if you had the money?

R1: no

I: why?

R1: because I was young.

I: can't children do their hair?

R1: but she treated me differently from her children. Besides it is those who have money that make it. When I did my hair, she made me sleep outside overnight, for not telling her. But her mother asked me to do so because I was an adult.

I: why did you leave eventually? 
R1: a lot of things happened. I needed to learn a trade. Meanwhile I wasn't paid for kneading the bread. She never bought clothing for me until end of the year, around Christmas. If I ever asked her to get me a dress that was similar to what she, my cousin wore, she would tell me I couldn't wear the same thing as hers. This means she thought of me as some worthless animal.

I: what else did she buy for you?

R1: after I did my hair, she never bought anything for me. I had to save from my lunch money to buy anything that I needed.

I: how much were you usually given?

R1: $\quad$ C2000 a day for food.

I: was that enough for food?

R1: no, not if I wanted to get satisfied.

l: $\quad$ who took care of you when you were ill?

R1: the husband gave me money for hospital.

I: did anybody take you?

R1: I always went all by myself.

I: even when you could not walk?

R1: somebody would walk with me if it were a short distance.

I: could you have left for your parents' on your own?

R1: no, because I didn't know anywhere, so they asked somebody to accompany me.

I: what made you leave?

R1: my mum visited the same week that I slept outside. They thought I had called to report too my mum.

I: $\quad$ but did you call?

R1: no, she said she saw me in a dream and in it, I was coiled up and shivering from the cold. But that was after eight years since I left them. She was scared about the dream so what happened there was an argument. She was asked why she paid us a visit. And my mum told them she had missed me because it had been such a long time since she saw me. So she decided to visit me.

I: what happened after that? 
R1: when my mum left, they went for another child and so asked me to leave. That was after about a month. She made someone accompany me to my parents.

l: what did you do after the new girl was brought in?

R1: my cousin never called me again to give me any work to do, but the child.

l: how old was the child?

R1: she was about 15 years. She had never been to school.

l: Do you communicate with your cousin and her family?

R1: no

I: Do you think you were a slave?

R1: yes.

I: why?

R1: she treated me in a way that made me feel I was not human.

I: but who is a slave?

R1: because I served them. A slave, I think is someone who has been brought to serve another person or groups of persons.

I: $\quad$ can you bake bread?

R1: yes

I: what do you do at the moment?

R1: my parents enrolled me in a hairdressing apprenticeship.

l: would you say that you benefited from your stay with them?

R1: no.

I: $\quad$ why in your opinion did your parents allow you to live with them?

R1: my father liked his sister. But he wasn't aware I would be given to my cousin who would maltreat me at the end of the day.

I: does he communicate with his sister?

R1: yes, but she feels ashamed and seems uncomfortable.

I: $\quad$ why do you say that?

R1: because they thought I would either get pregnant when I got back at my parents' or even become a destitute, but nothing like that has happened.

I: were you able to act without instructions? 
R1: no, I could only do what I had been told, or what I knew my cousin wanted. But I was alone and so could not do so many things at the same time.

I: who in your opinion is the head of your cousin's household?

R1: my cousin was more controlling that the man who is supposed to be the head. The woman is just too aggressive. Another thing, my mum used to send me some clothing through travelers. My cousin was usually upset though, and yet she would not bring any for me.

I: are you matrilineal or patrilineal?

R1: I am Asante and so matrilineal.

I: what about your cousin and her husband?

R1: she is Asante and the man is Fante.

1: what are their primary occupations?

R1: they are both bakers. They own the bakery I mentioned.

I: what are their educational backgrounds?

R1: I have no idea.

\section{Employer E5}

I: $\quad$ would you please estimate and tell me the number of house-helps that you've lived with?

E5: So many of them, because some of the children are already grown when they come here. They refuse to do what you want them to because they feel you impose things on them. When I see that's how they are, I send them away.

l: when you say that they are old, do you mean the growth in terms of age or what?

E5: some of them are as old as 20 , they are old. So when you ask them to do anything, they think you are forcing them to.

I: $\quad$ what is the youngest child you lived with?

E5: about 12

I: what is the oldest?

E5: 23

I: for how long did the youngest live with you?

E5: she was almost one year. 
I: you sent her away?

E5: yes [refutes her theory]

I: what was the longest that you lived with any of them?

E5: I think three years

I: so on average, how many years would you say that they lived with you?

E5: between one and two

l: where do you usually get them from?

E5: we don't normally go for them ourselves. When we need a child, we discuss it with somebody, that you need somebody to help you at home. Then they say they will go for one for you. I never went for any of the children I lived with.

I: are they your relatives?

E5: one of the two who went to work is my sister's daughter. Someone brought the other.

I: do you get to know their parents when you live with them?

E5: we invite them to come over. They have to know where the parents that the children live with, and to know whether they take good care of the children. So we invite them to come. At times, we go ourselves to visit the parents. Sometimes when you go with the girls to visit their parents, they want to go back on their return. You know when they meet their peer groups again in their hometowns, they become nostalgic.

I: how often did that happen to you?

E5: if you go for someone from Ankaful, Apewosika and the villages around, their own friends could ask them to come back home to look for a husband because they have become pretty. They are able to convince them to go away.

I: which do you prefer, males or females?

E5: I prefer the females

I: why

E5: because I have a small girl, a six year old girl. You may never know, she could be raped or anything could happen when you are not around. So I normally don't prefer boys.

I: do you think it is not cultural to prefer girls?

E5: no

I: have you ever had a house boy? 
E5: $\quad$ no

I: do you ask for girls from a particular ethnic group?

E5: no

I: does any ethnic group dominate the girls that you've lived with?

E5: I am an Nzema. I tried some girls from my hometown but they talked too much so I... they couldn't stay. They were even my relatives. Since then, l've always lived with Fantes.

I: $\quad$ what in your opinion, is the major problem associated with house-helps?

E5: I don't see any problem with them. The fact is she is helping you, and you are helping them. If you take good care of her, she would stay. If you don't she will leave. There are those that will want to leave at a certain stage, the good care you give them notwithstanding. They come here, they get a lot of clothing; I treat them like my own children. I give them what I give my own children. We eat the same food. I don't even dish out food for them, whether you are a house-help or not, you dish out your own food. I don't discriminate. So if the child is determined to stay, she could consider these incentives so that even when their parents come for them, they don't go. On the other hand, there are those that I ask to leave.

I: do you pay them, say on a monthly basis?

E5: there are those girls that are given to you on condition that you don't pay them, but... I had a girl whose mum asked me not to pay her but at puberty, I should come and perform the rites. When the time came, they told me what I had to buy for the ceremony.

I: how much did the things cost you?

E5: 150 (as in 150 thousand).

I: how long ago was this?

E5: about six years ago.

I: $\quad$ the cedi was about 500 to the dollar then

E5: yes, we bought so many things and gave them away, cloths, towels, shoes and cosmetics, and... a lot of things. Powder, they specified the quantity to buy.

I: how long did she live with you?

E5: one year. It was a beautiful ceremony. She wanted to go and get married. After the ceremony, she went away.

I: how old was she when she came to live with you?

E5: she was 20 when she came to live here. She lived with another family before coming to live here because of malnutrition - she wasn't well 
nourished - when she came she didn't even have breasts. She developed them when she came here. There are those families too who ask for specific sums. They tell you how much to pay the girl, like 50,000 or a 100,000 a month. When you pay them a 100,000 , there are some incentives that they won't get. When they ask for 50,000 , there are so many things that you will provide. There are some families which after paying the 50,000, the girls will not be provided with anything else, toiletries included.

I: So who receives the 50,000 or the 100,000 , is it the child or their families?

E5: some prefer that you keep it for them so that you give it to them when they are leaving. I was paying one of my girls 30,000 . In addition, I provided roll on, toiletries, soap, clothing and food. At the end of the month, I saved the 30,000 for her. I saved about 300,000 when her mother came for it. I later decided not to give it to her mother anymore, since the girl would be working for nothing. Because at the end of the day, she had to have something to show as the product of the services that she provided. If I gave everything to her, then the child would have worked for nothing. So when one day she came to ask for $100,000,1$ told her I had nothing for her. I told her she needed to learn a trade. When she started the apprenticeship, I stopped the savings for her. This is because when she gets out of the training, I have to provide her with at least a dryer and to set her up. When still asks me for everything that she needs.

I: $\quad$ what arrangements did that particular girl's parents make with you about her work and pay?

E5: she asked me to pay her. That is what they were coming for.

I: in your opinion, are children who live with other families slaves?

E5: I don't refer to them as slaves. However, if you look at the way some people treat their house-helps in this neighborhood, it is just an eyesore. My children talk about it when they come from church. They discuss these things when they meet at church, you know they meet their peer groups and talk. Some of them tell my girls that they, my girls are lucky and they the others would love to leave because of the treatment that they receive. I had one girl...

I: before you go on, would you consider those girls as slaves?

E5: yes, they make you know that you live with them, you are a slave. I can't do that because I know your mother gave birth to you like I did to mine. I also feel that it is probably because of one or two problems that you couldn't get to go to school, or to continue even if you did. So whatever the case, I don't have to treat you like a slave.

I: congrats, that's good of you 
E5: I went for this girl. One morning when she was pasting, a friend of mine came to see her and said: why should you let the girl who lives with you paste just like your own children? Why don't you give her some chewing sponge or some of the flowers around? My response was that if I don't take good care of her teeth and she gets infections...I mean each of us has his or her own cup, but when you are not around, she could use anybody's cups. Besides some children could be mean towards your children when they know you don't treat them like your own children. She could have bad ideas when she uses the chewing sponge and your children use toothpaste. When I am not around, they are the ones who take care of my children. If I am bad to them, they could take it out on my children or do the same thing to them when I am not there. So I treat everybody like my own children.

I: why do parents allow their children to live with other families?

E5: there are those who have so many children that they can't take care of. There are those who also get divorced and then the man refuses to take care of the children, or just deserts them. There are those who also think they their children have to live in the bigger cities for exposure. Others also think their children do misbehave and so they should send them away so they learn to behave.

\section{Recruiter A3}

I: how did you start recruiting children for families?

A3: the house I live in, where you just came to find me in, is owned by a professor in the History Department of University of Ghana. He had only one child but they lived in an isolated place. His wife is a medical doctor at the Korle Bu Hospital. So when both of them leave for work, they needed somebody to at least help them. I was living with them in this house. I was living here in this house and they were living at Oko. He asked me to go for a child for him ...

I: where is Oko?

A3: it's part of Dome. So I went for the child for him and because of the way the girl was serviceable. As a result, everybody who saw the child asked where he got her from. And he told them it was a friend of his called [name deleted]. I make sure that the children I bring have finished the J.S.S. and might be looking forward to going to the secondary school but can't because of financial problems. So they come to work. I arrange with them to work for like a year. I arrange with them so I could save some money for them. So if they work for sometime and feel that it is about time for them to leave, I give them their savings to go and learn a trade or to go back to school. 
I: $\quad$ what time did you start this?

A3: 1984

I: 1984, wow. So how many children have you brought so far?

A3: some of them don't stay for long. If I total all of them, I can count about 50 .

1: would they be more than 50 or less than that?

A3: it will be between 45 and fifty. At most fifty.

I: how many children, on average, do you bring a year?

A3: it depends. People won't request for children all the time. Besides I don't know everybody. Only my friends and the doctor's acquaintances who know I brought the child to him are those who ask. The fact is, I don't give the children to just anybody that I don't know. I have to know them personally or the professor or doctor will recommend a person as their friend or someone who won't maltreat the child before I bring them [but a wife complained several times that girls he brought to their house were abused by her husband and so they ran away. Yet he kept sending them to their house.]

I: how long did the first person that you brought to the doctor stay?

A3: $\quad$ she stayed for about six years.

I: where is she?

A3: she learnt a trade and has finished. She has even been married.

I: how old was she when she came to live with them?

A3: she had finished...then there was the elementary school so she finished the elementary school so she was about 15,16 or 17 years.

l: where do you get the children from?

A3: they are my own people that I know, or my relatives, so most of the time, from Mankessim or Fosu.

I: $\quad$ who do you know at Mankessim and Fosu?

A3: I am a Fante. I am from the Mankessim area, Asuohyia.

I: $\quad$ not all the children you bring are your relatives?

A3: no, that's what I am saying. We are farmers in the Fosu area so there are some people who aren't our real relatives but we've been with them for sometime, and we do refer to each other as relatives. We are not relatives per se, but when we went to live there from our respective hometowns, like from Mankessim or Asuohyia to go and farm there. There are some people who live there but are not even Fantes, and yet 
we consider all of them as relatives. It is possible they saw how the girls that I brought had turned out when they returned home from living here. So when I go, they tell me they have a child available so if I need a child to go and live with somebody, I should come for her.

I: what is the youngest age that you have brought so far?

A3: between 16 and 17 . The oldest age was 20 . The elites usually don't like girls who are too old, especially the madams. When they come, their husbands try to trouble them. So usually, they are at least 18 and 20.

1: so how old has the youngest child been?

A3: 16

I: so are you saying that out of the 50 children that you've brought, you can't get even one person who might have dropped out of school when you went for her?

A3: my children are always... because the people I bring them to are lecturers who always speak English. The person who dropped out of school will have problems with the language, the language could be a problem but those who finished the J.S.S. could express themselves [which is hardly the case for most of the people who went to school in the villages, they can't speak English].

I: how many years did the longest staying child live with the 'employer?'

A3: the longest staying person spent about 15 years.

I: $\quad$ with the same person?

A3: yes

I: $\quad$ when did you bring that person?

A3: let's see, that was in '85.

I: $\quad$ when did that person leave?

A3: I didn't calculate but I know she lived for 15 years. She even got married while living there. She had a wedding. She lived with [name deleted]. I sent her to her. When she came she was about 18 years and she lived there till she was about 28 years. The woman lived with her so nicely people thought she was her own child.

I: $\quad$ what is the shortest time that anybody stayed?

A3: those who didn't stay, some of them lived for just three days, four days. It depends. Some of them complain that the place is so quiet, especially at Legon and the Achimota College.

I: do they make complaints to you? 
A3: yes, once in a while.

I: what are their complaints?

A3: the complaints that they bring...the complaints... as I said, some of them complain the place is too quiet for them. Some people complain the place is so quiet. I recall I sent a girl to somebody at East Legon. The girl was like 16 and she complained the man wanted to sleep with her. I told her that was a difficult thing to discuss so if the man tried again, she should shout so people around could here. That way, they would discover it without anybody having to report him.

I: what other complaints do you hear?

A3: these are the most serious complaints I got because most of the time, if I don't know the person, I won't give a child to them [and because he doesn't want to jeopardize his relationship with his clients, he would rather not confront the employer when they abuse the children].

I: don't they beat the children?

A3: no, not my people

I: what about yelling and insults. Are they not insulted?

A3: that's what I talked about. If I know you are harsh towards children or if I know you maltreat children, I won't bring my child to you [l observed one of his children and wasn't too pleased at the way she was addressed in her house] because I don't want to jeopardize my reputation. This is because when the child comes and they go back, they recommend me and if I don't bring them to good people, they could say bad things about me, saying that I sent them to bad people. So I have to know them before I could give the child away.

I: do you pay them?

A3: do I pay who?

I: are the children that you bring paid?

A3: none of them has never been paid.

I: how do they pay them?

A3: when I bring them, I discuss it with you [meaning the employer]. I tell them they have finished the J.S.S. and they are looking for people to live with. As they live with you, you should pay this or that amount per month. I discuss it with them.

I: how much are they paid per month? 
A3: in the beginning, for a sixteen year old, they will give you about 60,000 because they will feed you, cloth you. We will accumulate that money for them.

I: do they give it to you or...

A3: most of the time, I ask them [the employers] to keep it.

I: they don't give it to you but do they give it to the children themselves?

A3: they don't give it to the children. The parent who is maintaining the child [that is the employer] keeps it until she is leaving for good, or when you [the employer] say you've lived with her for sometime and that you no longer need her services. Then we calculate the amount you should pay her based on the number of months she stayed.

I: what is the highest accumulated income that you received for a child?

A3: the last person received about 80,000 . She stayed there for 8 years and when we calculated it at the time that she was leaving, she received about 1 million.

I: how old was she when she came to live there?

A3: $\quad$ she was about 16 years

l: $\quad$ what arrangements do you make with them when you go for them?

A3: when I go to my hometown for them, as I told you, because of my popularity stemming from the first child that I brought... when I go and tell them I have a job for their children, the fathers look up to me as their representatives here. They tell me what they would want me to relay to the 'employers' on their behalf. When I bring them, I tell the 'employers' exactly what the parents told me.

I: so what do the parents tell you and what do they expect from their children's work?

A3: as I told you, they judge me according to the first girl that I brought. They consider what the girl had with her when she returned home. When you go, they tell you, they would want their children to acquire the same things as the others.

I: so they don't tell you that after say two years, they would want their children to go back to school or to learn a trade?

A3: hmmm, it's just on two occasions that the parents told me I should bring their children to them after two years. A woman at Fosu told me her girl had lived with somebody before so if I was bringing her, after two years, we should use her earnings to buy a machine for her to learn a trade.

I: did she live for the two years? 
A3: yes

I: the employers, what do they usually ask for, girls or boys?

A3: they used to ask for girls. It's only recently that the men started asking for boys.

1: why did they ask for girls?

A3: because most of the time, they wanted somebody to cook or do the laundry and little things like that. They think the girls are good on that.

I: $\quad$ why do they think the girls are good on that?

A3: you know that women are good with cooking, because when the man and the woman are going to work, they feel if they had somebody at home, the person could cook for them or if the woman cooks on weekends, such a person would help her cook and keep in the refrigerator. The boys are usually needed to take care of the gardens or flowers but the lecturers at Legon or even with the government workers, most of them have workers to do these for them that is why they usually ask for the girls.

I: do they pay you?

A3: they don't pay me. However, when I am going away, the man gives me money for transportation because he is the one sending me and he can't ask me to use my own money to go for somebody to work for him [but respondent visits hometown... does that mean it saves him the transportation?]. So most of the time, I get my lorry fare, in and out, as well as that for the person that I will be bringing. Most of the time when I go, the parents won't have money for their transportation so I will have to pay their transport fare.

I: $\quad$ the children that you go for, can they visit their parents?

A3: why not? We celebrate the annual festival and when that time comes, I ask for the permission to go with them for three or four days [that will be a big entourage given that he always has a lot of people living in Accra at the same time].

I: are their parents able to visit them?

A3: yes, some of their parents even stay for seven days when they come.

I: do they have freedom in their homes?

A3: I go to their homes a lot, and if I visit any of them and discover that they don't have their freedom, I move them and reassign them.

I: how often do you reassign them?

A3: once in a while 
I: how many did you reassign this year?

A3: we are now in May so I haven't done any yet.

I: how many times did you experience that during last year?

A3: only once. That's what I mentioned earlier, about the girl whose 'employer' wanted to rape her. She ran away. When I asked her to shout if he did that, the person couldn't wait to do that. When the man left for work, she parked her things and escaped to my place.

I: how often do you hear that?

A3: where the man wants to sleep with the children?

I: yes

A3: that's two or three occasions, it's not common.

I: $\quad$ why do parents allow their children to live with other families?

A3: it is financial, mostly financial. There are some people also who believe it won't be a good thing for them to live their entire lives in the villages. At Fosu in our village for instance, we see vehicles like once a week. I know some girls that I brought here sometime ago and if you saw them, you might not believe she had even lived in a village. The way they talked, dressed and their mannerisms had all changed. So they prefer to come to the cities to get polished or to learn.

I: $\quad$ are there any other reasons?

A3: pregnancy rates are higher in the rural area than here. In all the ten years or fifteen years that I have been bringing children here, none of them has become pregnant. Most of the time, they live in a walled house and even where there is no security, you can't go out without being noticed. In the villages, however, they girls could just say they are visiting their friends and would be back soon, but might be going to see their men. So it is helpful when they come to the cities. There is another girl that I brought here eight years ago. All her peers have become pregnant or have given birth, but she is here and hasn't become pregnant. Her mother is therefore happy I got her out of the village.

I: do the parents approach you, telling you that they have a child for you to bring to the city?

A3: most of the time. Initially I had to go looking for the children, but later, it is the parents who look for me. After the first three girls... when they came and became nice... it is the parents that have been coming to me. There is another girl, J.... whom I brought to Dr. ... They sent her to learn a trade. She is married now and lives at Osu. She is married and they have their own car. So if anybody hears I brought her and she got the husband and also got the car, they mostly look for me. 
1: do you pay the parents?

A3: the parents at times expect that after a year, they should be given part of their children's money. Some of the parents that the children live with do understand when I explain it to them, that it is they who gave birth to the children and so could give may be 200,000 to be given to the parents. There are those who argue that they were supposed to take care of their children. They failed to do that and I am taking care of them so I have nothing to give them. So there are two things. There are those who understand, and those who will never understand.

l: between the parents and the children, who decides that the children go to live with other families?

A3: most of the times, it is the mothers.

I: the mothers, what about the fathers, don't they take part in the decisionmaking?

A3: the men don't take part in it. Some of the fathers even refuse to let the children come with me.

I: why do they refuse?

A3: they also feel that it is the girls' duties to cook and do the laundry. They feel they could stay to help them also.

I: you said some employers ask for boys. Do the fathers refuse to let them leave?

A3: no, I usually don't have problems with boys.

I: $\quad$ can the child refuse to come?

A3: the parents usually discuss it with the child and the child get the understanding before I even go there.

I: $\quad$ so does it seem like we [the parents] have taken the decision so you [our child] will go away, or they give the child a choice?

A3: there is a girl in this area, when I went for her after her J.S.S., her parents told her younger sister that she will be coming with me when she also finished. As soon as she finished, I went for her.

I: $\quad$ so can the child say no, they are not leaving?

A3: I don't encounter such instances.

I: $\quad$ are you married?

A3: yes

I: how many children do you have? 
A3: I went to Nigeria in ' 82 and got back in ' 83 . when I got back, my uncle told me I was related to that woman so I could marry her. I had a child with her. I have married since and have two children with her. So I have three children.

1: how old are they?

A3: I had the oldest in 84 so.

I: $\quad$ she is about 20

A3: yes, she goes to school at Mankessim

I: what secondary school is at Mankessim?

A3: Mankessim secondary Technical.

I: what about the other two?

A3: they are young. One of them is seven and the other four years.

I: in your opinion, are children who live with other families slaves?

A3: I don't see them as slaves. If some people enslave theirs, mine are not. Look at this man [mentions name] whom I brought a child to. I know he is a decent person who will not maltreat any child I bring to him. Besides his house is very close to mine and every morning I can pass by to see how the children are doing. When they go on errands, the children sometimes come to visit me. All the others are the same, I know them that is why I bring them the children [but this is the man whose wife complains that he sleeps - not just tries - with the girls that he brings].

I: yea, but I heard you keep bringing new children to him all the time. What problems do the children have with him?

A3: one of the girls is my friend's niece. He is a security at Legon. He went for her to send to somebody but the person was not ready. Meanwhile, his wife didn't want to live with that girl so he forced me to look for somebody for her to live with. I was there one day when she came to me and said that she wanted to go back to her uncle so she could learn a trade.

I: why, didn't this man send her to learn the trade?

A3: no, she had only stayed for five months.

I: how old was she?

A3: $\quad$ she was about 15 and 16

I: and you said your minimum age was 16 . Ok, I am done with you for now, if I remember any questions, I would be back to see if you can answer 
them for me. Thank you very much. But in the meantime, do they tell you the number of hours they work in a day?

A3: they've never mentioned it to me, so I don't know

I: do you know when they sleep?

A3: because they watch TV, some of them sleep between 9.30 and 10 .

I: $\quad$ when do they wake up?

A3: 5.30 . You know the life in Accra. When they wake up, there are certain little, little things you might want to do for the woman.

I: little things like what?

A3: you might sweep the kitchen, some of them might want you to make hot water for them, and you will have to do this before she wakes up.

I: you have to do this before the person wakes up...

A3: you must do it before she wakes up. You shouldn't wait to do them when she wakes up, say to clean the house.

I: $\quad$ what else do they do, house chores?

A3: I haven't brought anybody who sold things in the street. They have never been made to work for their employers to collect the money. I haven't anything like that. Most of them stay at home to take care of the place when everybody goes to work.

I: do you give them any training when you bring them?

A3: most of the time I talk to them. I tell them about how the first girls I brought managed to stay for long. I tell them about that. I don't give them any real training, but use the first group as reference...the first girl I brought like this never went out in the night. The man never came back home to see her standing in the street so she was able to stay for a long time there. So when they come, I tell them about her, that I brought her here, she stayed for this number of years and it is because of this and that.... I don't give them any special training.

l: thank you very much. You've been very helpful. 
VITA

CECILIA NANA DERBY

Born Takoradi, Ghana

1997

B.A. (Hons.) Sociology

University of Cape Coast

Cape Coast, Ghana

1997

Diploma in Education

University of Cape Coast

Cape Coast, Ghana

1997-1998

Teaching and Research Assistant

University of Cape Coast

Cape Coast, Ghana

1998

Workshop Participant: Social/Demographic Survey Skills University of Cape Coast

Cape Coast, Ghana

1998-1999

Economics Tutor

St. Augustine's College

Cape Coast, Ghana

$2000-2005$

Teaching Assistant and Instructor

Department of Sociology and Anthropology

Florida International University

2001

Research Assistant

International Hurricane Research Center

Florida International University

2003

M.A. Comparative Sociology

Florida International University

2003

Nominee: 2002 -2003 Who's Who Among American

Universities and Colleges in Recognition of Outstanding Merit and Accomplishment as a Student at Florida International University 

2003-2004 Scholarly Forum. Paper entitled "Contemporary Slavery, Awareness and Understanding."

Graduate Student Association

Florida International University

2004

Third Place Winner: 2003-2004 Teaching Assistants'

Excellence in Teaching Award.

Academy for the Art of Teaching

Florida International University

Miami, Florida

2005 Instructor,

Department of Social Sciences

Miami Dade College

\section{PUBLICATION AND PRESENTRATIONS}

Derby, C. N. (2004). The Case against the medicalization of female mutilation. Canadian Woman Studies, 24(1), 95-100

Derby, C. N. (2004). Awareness and Understanding of Contemporary Slavery Paper presented at Barry University's celebration of Slavery Day, March 17, 2004.

Derby, C. N. (2004). Child Labor is the Slavery of our Time. Conference Paper, 2004 Annual Meeting of the American Sociological Association in San Francisco.

Derby, C. N. (2003). The causes and characteristics of "Contemporary Slavery": Impact on women and children. Canadian Woman Studies, 22 $(3,4)$ 60-65.

Derby, C. N. (2002). Female Genital Mutilation: a Sociological Analysis of the Movement against a Primitive Tradition. A paper presented at a roundtable discussion at the 2002 Annual Meeting of the American Sociological Association in Chicago.

Derby, C. N. (2001). Towards a Conceptual Framework for Understanding Contemporary Child Labor Slavery - presented at the 2001 Annual Meeting of the American Sociological Association in Orange County, California. 